
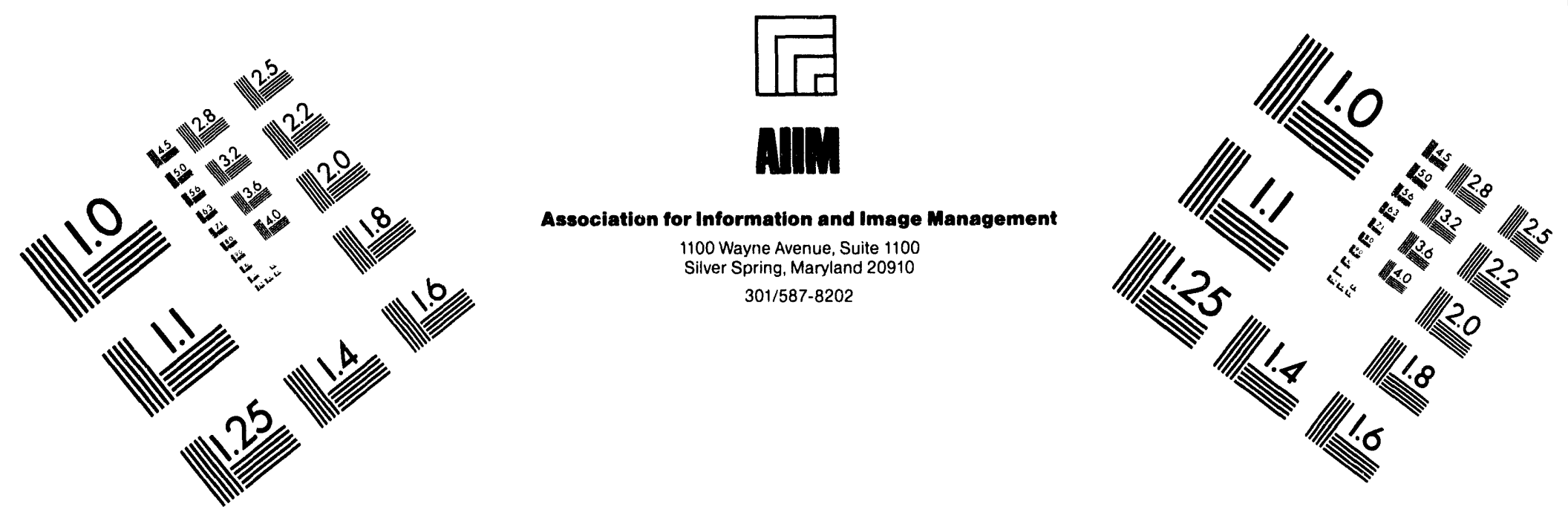

Centimeter

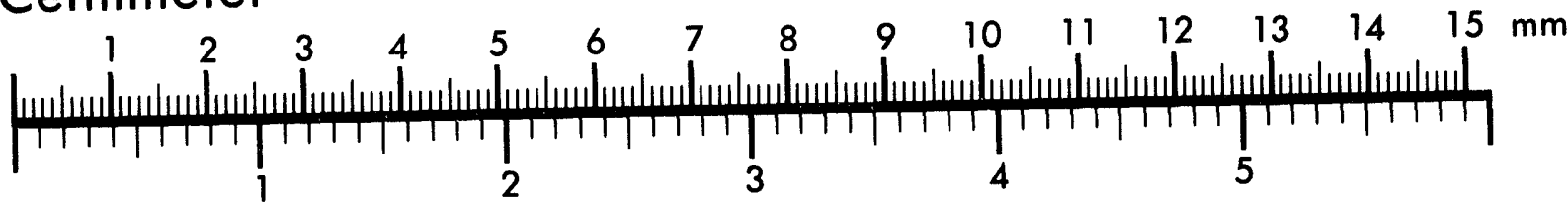
Inches
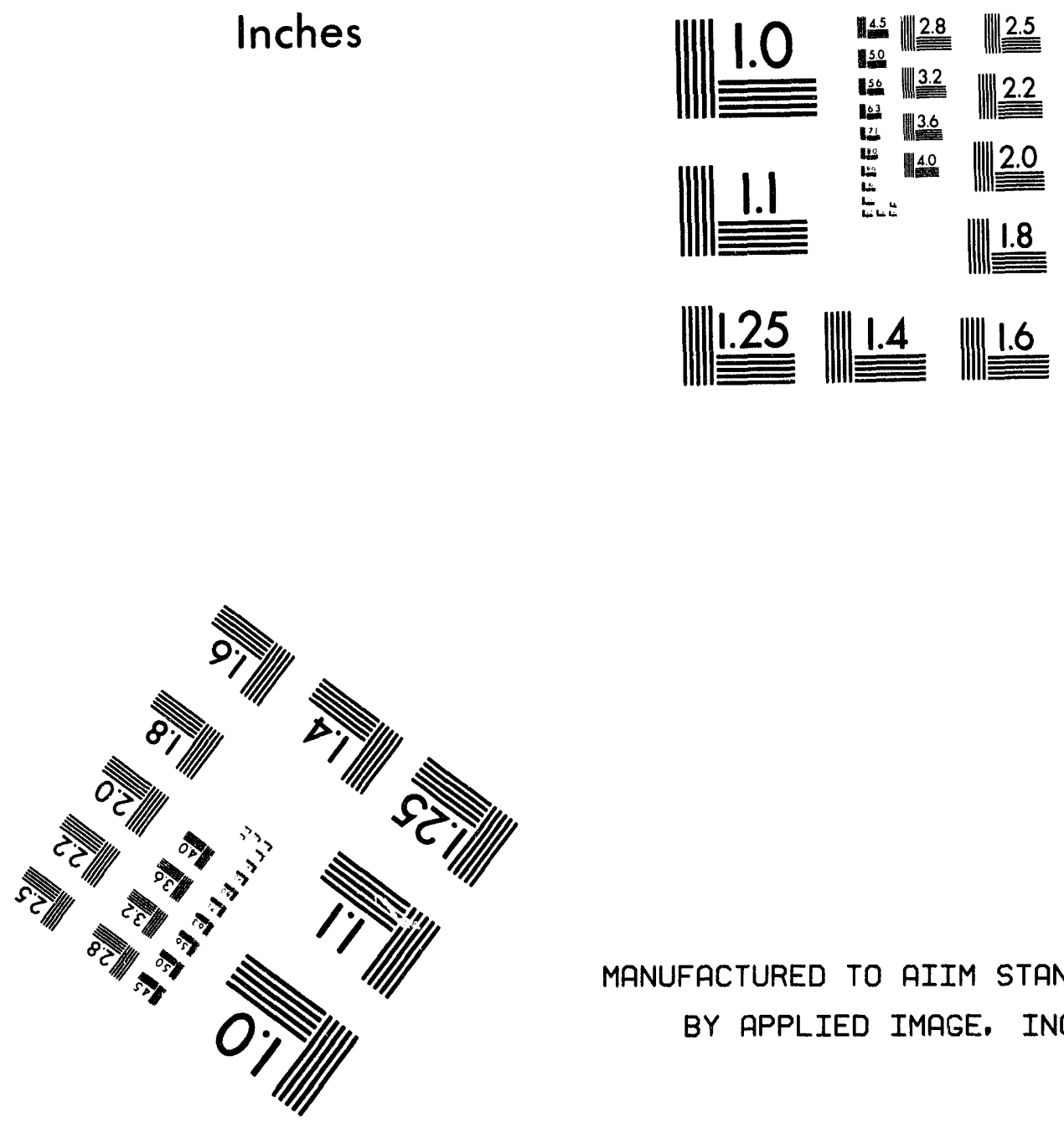

MANUFACTURED TO AIIM STANDARDS BY APPLIED IMAGE, INC.

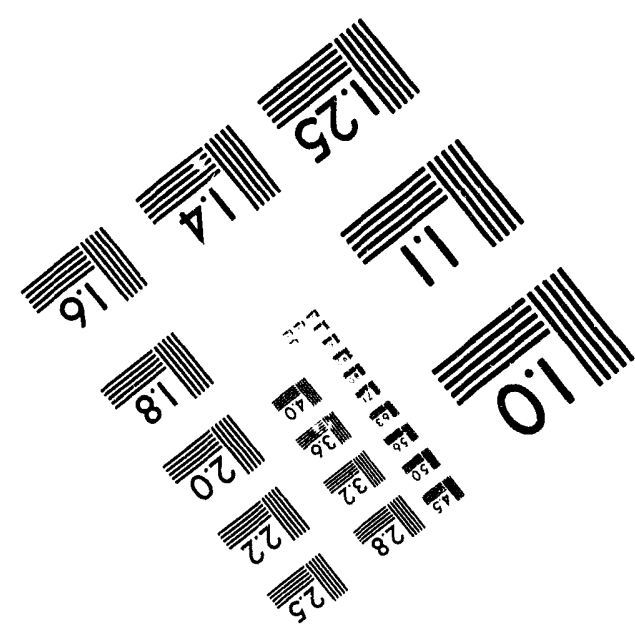



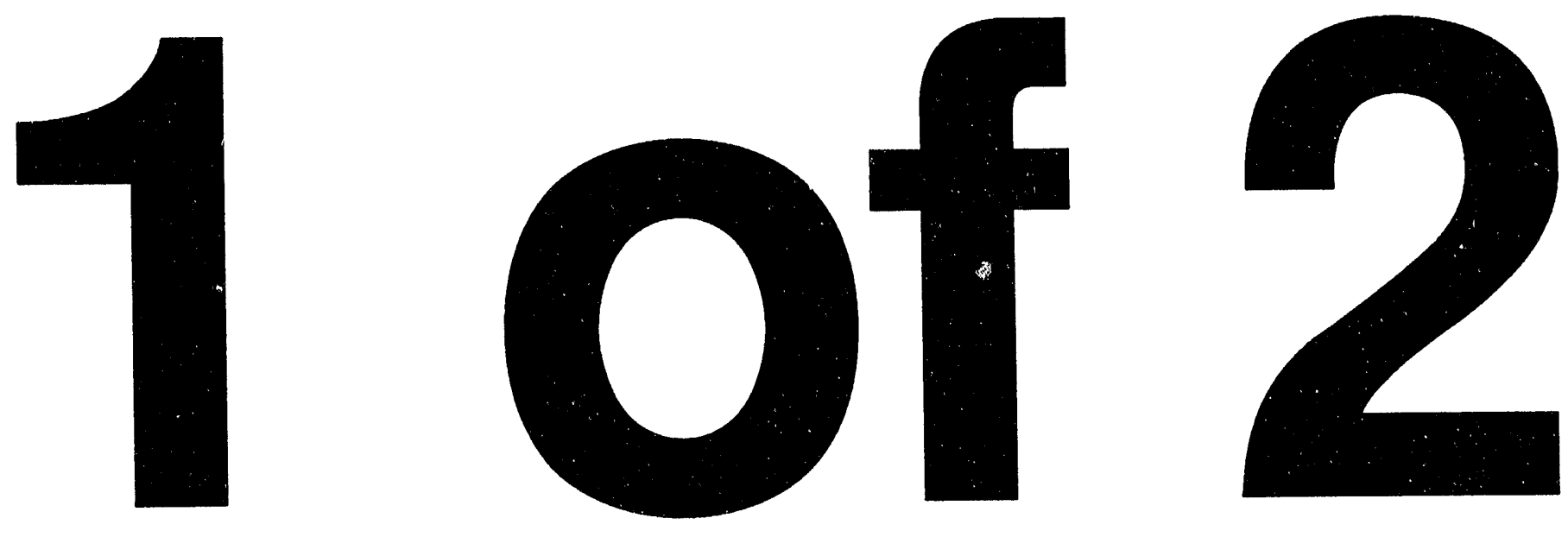


\section{Hanford Emergency Response Plan}

Date Published

April 1994

Approved for Use and Application by:

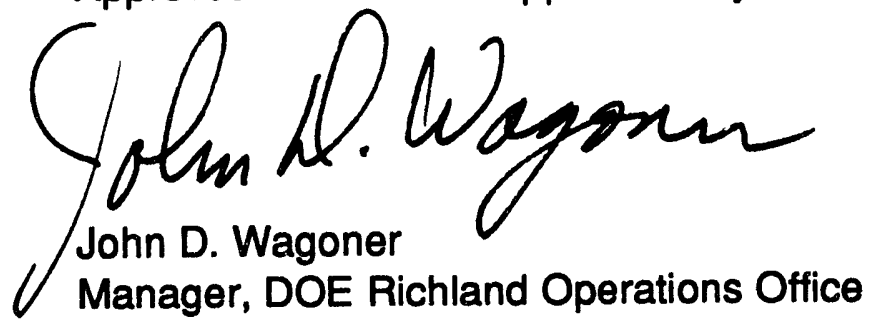

Prepared for the U.S. Department of Energy

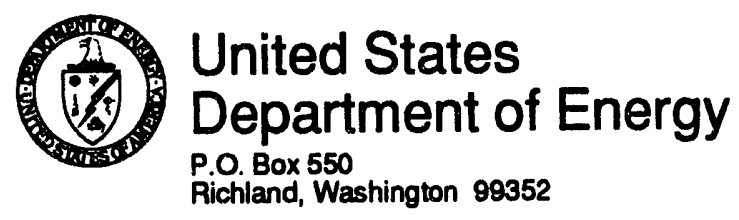

Approved for Public Release 


\section{LEGAL DISCLAIMER}

This report was prepared as an account of work sponsored by an agency of the United States Government. Neither the United States Government nor any agency thereof, nor any of their employees, nor any of their contractors, subcontractors or their employees, makes any warranty, express or implied, or assumes any legal liability or responsibility for the accuracy, completeness, or any third party's use or the results of such use of any information, apparatus, product, or process disclosed, or represents that its use would not infringe privately owned rights. Reference herein to any specific commercial product, process, or service by trade name, trademark, manufacturer, or otherwise, does not necessarily constitute or imply its endorsement, recommendation, or favoring by the United States Government or any agency thereof or its contractors or subcontractors. The views and opinions of authors expressed herein do not necessarily state or reflect those of the United States Government or any agency thereof.

This report has been reproduced from the best available copy. Available in paper copy and microfiche.

Available to the U.S. Department of Energy

and its contractors from

Office of Scientific and Technical Information

P.0. Box 62

Oak Ridge, TN 37831

(615) $576-8401$

Available to the public from the U.S. Department of Commerce National Technical Information Service

5285 Port Royal Road

Springfield, VA 22161

(703) $487-4650$

Printed in the United Statos of Amorice 


\section{CONTENTS}

1.0 INTRODUCTION $\ldots \ldots \ldots \ldots \ldots \ldots \ldots \ldots \ldots \ldots \ldots \ldots \ldots \ldots \ldots \ldots \ldots \ldots$ 1-1

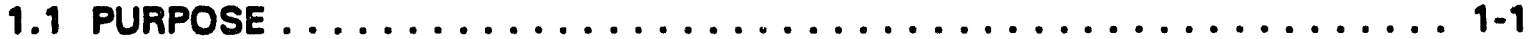

1.2 SCOPE ................................ 1-1

1.3 CONCEPT OF OPERATION . . . . . . . . . . . . . . . . . . 1-2

1.3.1 Hanford Site Emergency Management Program Basis . . . . . . . . . 1-2

1.3.2 Hanford Site Emergency Response Roles . . . . . . . . . . . . . 1-3

1.4 SITE DESCRIPTION . . . . . . . . . . . . . . . . . . . . . 1-3

1.4.1 Overview Site Description ..................... 1-3

1.4.2 Physical Attributes of the Hanford Site . . . . . . . . . . . 1-6

2.0 EMERGENCY RESPONSE ORGANIZATION (INTERNAL) $\ldots \ldots \ldots \ldots \ldots \ldots .2$-1

2.1 ORGANIZATION STRUCTURE .................... 2-1

2.1.1 Hanford Site Contractors .................... 2-1

2.1.2 U.S. Department of Energy,

Richland Operations Office .................. 2-4

2.2 EMERGENCY DIRECTION AND CONTROL . . . . . . . . . . . . . . 2-5

2.2.1 Building Emergency Organization . . . . . . . . . . . . . . 2-5

2.2.2 Event Command Post . . . . . . . . . . . . . . . . . . 2-7

2.2.3 Area Emergency Control Centers . . . . . . . . . . . . . . . . . . 2-8

2.2.4 Emergency Management Center ... . . . . . . . . . . . . . 2-10

2.2.5 Occurrence Notification Center ... . . . . . . . . . . . . . . . 2-11

2.2.6 RL Emergency Control Center .................... 2-11

3.0 OFFSITE RESPONSE INTERFACES $\ldots \ldots \ldots \ldots \ldots \ldots \ldots \ldots \ldots \ldots \ldots \ldots$ 3-1

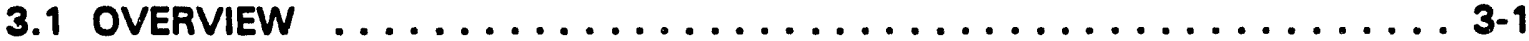

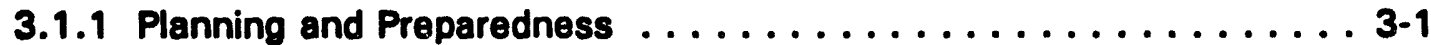

3.1.2 Response and Recovery $\ldots \ldots \ldots \ldots \ldots \ldots \ldots \ldots \ldots \ldots \ldots, \ldots \ldots \ldots$

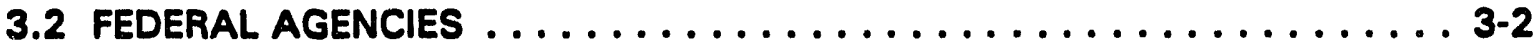

3.2.1 Department of Energy-Headquarters . . . . . . . . . . . 3-2

3.2.2 Federal Bureau of Investigation $\ldots \ldots \ldots \ldots \ldots \ldots \ldots \ldots \ldots .3 .2$

3.2.3 U.S. Coast Guard ....................... 3-4

3.2.4 U.S. Environmental Protection Agency ............... 3-4

3.2.5 Federal Aviation Administration ................. 3-4

3.2.6 Federal Emergency Management Agency . . . . . . . . . . 3-5

3.3 STATE GOVERNMENT $\ldots \ldots \ldots \ldots \ldots \ldots \ldots \ldots \ldots \ldots \ldots \ldots \ldots$

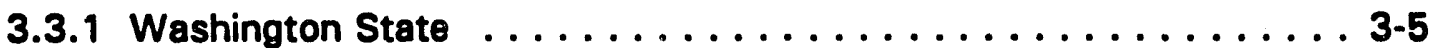

3.3.2 Oregon State ..................... 3-6

3.4 LOCAL ORGANIZATIONS $\ldots \ldots \ldots \ldots \ldots \ldots \ldots \ldots \ldots \ldots \ldots \ldots$

3.4.1 Plume Emergency Planning Zone Counties . . . . . . . . 3-7

3.4.2 Ingestion Emergency Planning Zone Counties ........... 3-9

3.5 TRIBAL ORGANIZATIONS $\ldots \ldots \ldots \ldots \ldots \ldots \ldots \ldots \ldots \ldots \ldots \ldots$

3.6 PRIVATE ORGANIZATIONS $\ldots \ldots \ldots \ldots \ldots \ldots \ldots \ldots \ldots \ldots \ldots \ldots$

3.7 MEMORANDA OF UNDERSTANDING $\ldots \ldots \ldots \ldots \ldots \ldots \ldots \ldots \ldots \ldots$

4.0 ASSESSMENT AND CLASSIFICATION $\ldots \ldots \ldots \ldots \ldots \ldots \ldots \ldots \ldots \ldots$ 4-1

4.1 HAZARDS ASSESSMENT $\ldots \ldots \ldots \ldots \ldots \ldots \ldots \ldots \ldots \ldots \ldots \ldots \ldots$ 4-1 
4.2 OPERATIONAL EMERGENCY CLASSIFICATION $\ldots \ldots \ldots \ldots \ldots \ldots \ldots \ldots$

4.2.1 Emergency Classes . . . . . . . . . . . . . . . 4-2

4.3 EMERGENCY ACTION LEVELS $\ldots \ldots \ldots \ldots \ldots \ldots \ldots \ldots \ldots \ldots \ldots \ldots$

4.3.1 Symptom Based Emergency Action Levels . . . . . . . . . . . . . 4-5

4.3.2 Event Based Emergency Action Levels . . . . . . . . . . . . . . . 4-6 . . . . . . . .

4.3.3 Emergency Action Level Development . . . . . . . . . . . . . . 4-6

4.3.4 Use of Emergency Action Levels . . . . . . . . . . . . . . . 4-7

4.4 CONSEQUENCE ASSESSMENT $\ldots \ldots \ldots \ldots \ldots \ldots \ldots \ldots \ldots \ldots$

4.4.1 Consequence Assessment Requirements . . . . . . . . . . . . . 4-8

4.4.2 Event Scene Consequence Assessments . . . . . . . . . . . . 4-9

4.4.3 Area Consequence Assessments . . . . . . . . . . . . . . . 4-9

4.4.4 Coordination of Consequence Assessment Results . . . . . . . 4-9

5.0 PROTECTIVE ACTIONS ....................... 5-1

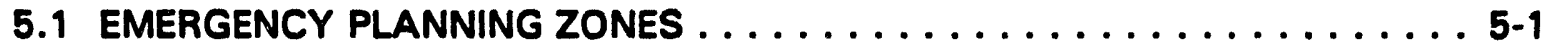

5.1.1 Plume Exposure Pathway Emergency Planning Zones . . . . . . . . . 5-1

5.1.2 Ingestion Exposure Pathway Emergency Planning Zone . . . . . . 5 5-2

5.2 PROTECTIVE ACTIONS . . . . . . . . . . . . . . . . 5 5

5.2.1 Protective Action Guides . . . . . . . . . . . . . 5-5

5.2.2 Emergency Response Planning Guidelines

for Nonradiological Releases . . . . . . . . . . . . . . . . 5-6

5.2.3 Onsite Protective Actions . . . . . . . . . . . . . . 5-6

5.2 .4 Offsite Protective Actions . . . . . . . . . . . . . . 5-8

5.2.5 Protective Equipment and Supplies $\ldots \ldots \ldots \ldots \ldots \ldots \ldots$ 5-9 $\ldots \ldots$. . .

5.2.6 Event Termination . . . . . . . . . . . . . . . . . 5 5-9

6.0 NOTIFICATIONS AND COMMUNICATIONS $\ldots \ldots \ldots \ldots \ldots \ldots \ldots \ldots \ldots$

6.1 NOTIFICATION $\ldots \ldots \ldots \ldots \ldots \ldots \ldots \ldots \ldots \ldots \ldots \ldots \ldots \ldots . \ldots \ldots$

6.1 .1 Initial Notifications . . . . . . . . . . . . . . . . 6-1

6.1 .2 Offsite Notification ....................... 6-1

6.1 .3 Onsite Notification . . . . . . . . . . . . . . . . . . 6-4

6.1.4 U.S. Department of Energy Assets . . . . . . . . . . . . . . 6.5

6.2 COMMUNICATIONS ....................... 6-5

6.2.1 Telephone Number $911 \ldots \ldots \ldots \ldots \ldots \ldots \ldots . \ldots \ldots$. . . . . . . . . . .

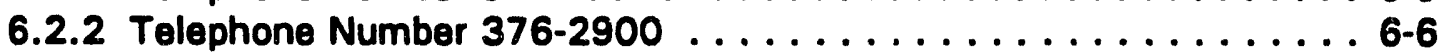

6.2.3 Crash Alarm Telephone System . . . . . . . . . . . . . . . . 6-6

6.2.4 Emergency Notification System . . . . . . . . . . . . . . . 6.6 6 6

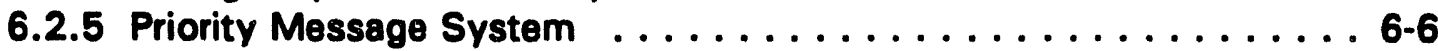

6.2.6 Radios ............................. 6-6

6.2.7 Event Command Post Communications . . . . . . . . . . 6-7

6.2.8 Emergency Control Center Communications . . . . . . . . . . 6-7

6.2.9 Secure Communications . . . . . . . . . . . . . . 6.8 6-8

6.2.10 Emergency Signals . . . . . . . . . . . . . . . . . 6.8 6

7.0 EMERGENCY MEDICAL SUPPORT $\ldots \ldots \ldots \ldots \ldots \ldots \ldots \ldots \ldots \ldots \ldots$

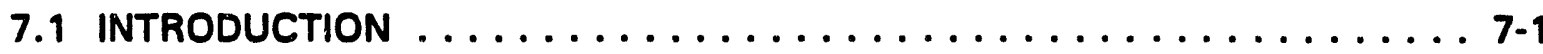


CONTENTS (cont)

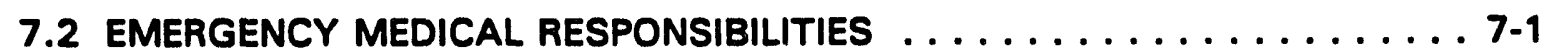

7.2.1 Hanford Environmental Health Foundation . . . . . . . . . 7-1

7.2.2 Hanford Fire Department ................... 7-1

7.2.3 Other Hanford Site Contractors . . . . . . . . . . . 7-1

7.3 MEDICAL EMERGENCY CATEGORIES . . . . . . . . . . . . . 7-2

7.3.1 Category 1: Mass Casualty .................. 7-2

7.3.2 Category 2: Contaminated Injury . . . . . . . . . . . . 7-2

7.3.3 Category 3: Job Accident/Injury . . . . . . . . . . . . . . 7-2

7.3.4 Category 4: Other Emergency Medical . . . . . . . . . . . . 7-2

7.3.5 Fatalitios . . . . . . . . . . . . . . . . . . . . 7-3

7.4 MEDICAL EMERGENCY FACILITIES AND EQUIPMENT $\ldots \ldots \ldots \ldots \ldots \ldots$

7.4.1 Emergency Decontamination Facility . . . . . . . . . 7-3

7.4 .2 Health Service Centers . . . . . . . . . . . . . . . 7-3

7.4.3 Site Decontamination Equipment . . . . . . . . . . . 7-3

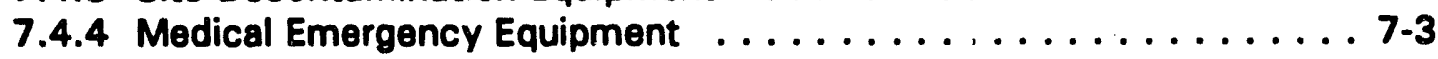

7.4.5 Medical Emergency Transportation . . . . . . . . . . . . . . 7-4

7.4.6 Medical Emergency Communications . . . . . . . . . . . . 7-4

7.4.7 Offsite Medical Facilities . . . . . . . . . . . . . . . . . 7-4

8.0 RECOVERY AND REENTRY $\ldots \ldots \ldots \ldots \ldots \ldots \ldots \ldots \ldots \ldots \ldots \ldots \ldots$

8.1 TERMINATION OF THE EMERGENCY $\ldots \ldots \ldots \ldots \ldots \ldots \ldots \ldots \ldots \ldots$

8.2 REENTRY .............................. 8-1

8.2.1 Reentry Exposure Considerations . . . . . . . . . . . . 8-2

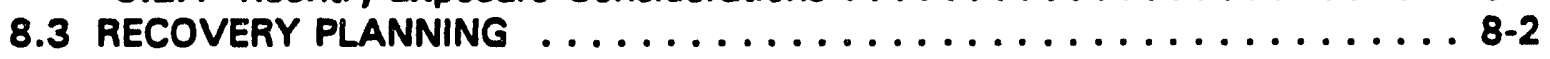

8.3.1 Planning and Operations for Onsite Recovery . . . . . . . . . 8-2

8.3.2 Planning and Operations for Offsite Recovery . . . . . . . . . 8-5

9.0 PUBLIC INFORMATION $\ldots \ldots \ldots \ldots \ldots \ldots \ldots \ldots \ldots \ldots \ldots \ldots \ldots \ldots . \ldots \ldots$

9.1 EMERGENCY PUBLIC INFORMATION ORGANIZATION $\ldots \ldots \ldots \ldots \ldots \ldots .9 .9$

9.1.1 U.S. Department of Energy Emergency

Action and Coordinating Team . . . . . . . . . . . . . 9-1

9.1.2 Joint Information Center . . . . . . . . . . . . . . . 9-2

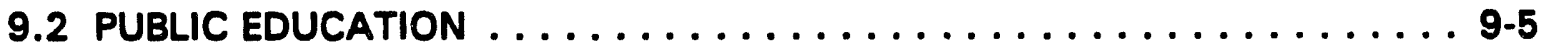

9.2.1 Plume Emergency Planning Zone Public Education . . . . . . . . . . 9-5

9.2.2 Ingestion Emergency Planning Zone Public Education . . . . . . . . . 9-6

9.3 SITE PERSONNEL EDUCATION $\ldots \ldots \ldots \ldots \ldots \ldots \ldots \ldots \ldots \ldots \ldots$

10.0 EMERGENCY FACILITIES AND EQUIPMENT $\ldots \ldots \ldots \ldots \ldots \ldots \ldots \ldots$

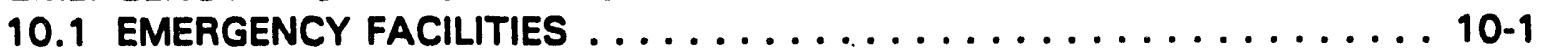

10.1.1 Event Command Post . . . . . . . . . . . . . . 10-1

10.1.2 Operations Support Center .................. 10-1

10.1.3 Area Emergency Control Center . . . . . . . . . . . . . . 10.1

10.1.4 Emergency Management Center ................ . 10-3

10.1.5 Occurrence Notification Center ................. 10-3

10.1.6 Hanford Patrol Operations Center ............... . . 10-3 


\section{CONTENTS (cont)}

10.1.7 U.S. Department of Energy, Richland Operations Office

Emergency Control Center . . . . . . . . . . . . . . . . . 10-3

10.1.8 Alternate Emergency Control Center . . . . . . . . . . . . . . . 10.4

10.1.9 Joint Information Center . . . . . . . . . . . . . . . . . . . 10 10-4

10.1.10 Unified Dose Assessment Center/

Field Team Coordination Center . . . . . . . . . . . . 10-5

10.1.11 Medical Emergency Facilities . . . . . . . . . . . . . . . . . 10-5

10.1.12 Protective Clothing Cleaning . . . . . . . . . . . . . . . . 10-5

10.1.13 State and County Emergency Operations Centers . . . . . . . . 10-6

10.2 EMERGENCY EQUIPMENT ...................... 10.6

10.2.1 Assessment Equipment ................... 10.7

10.2.2 Decontamination Operation Equipment . . . . . . . . . . . 10-8

10.2.3 Evacuation Buses Nehicles .................. 10-8

10.2.4 Hanford Patrol . . . . . . . . . . . . . . . . . . . . . . . 10-8

10.2.5 Hanford Fire Department . . . . . . . . . . . . . . . 10-8

10.3 MAINTENANCE AND TESTING OF ALARM AND

COMMUNICATION SYSTEMS .................... 10-9

10.4 INVENTORY OF EMERGENCY EQUIPMENT $\ldots \ldots \ldots \ldots \ldots \ldots$. . . . . . . . . .

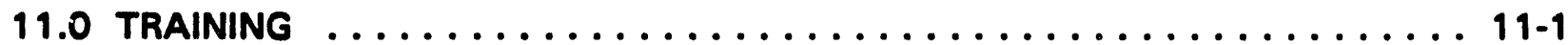

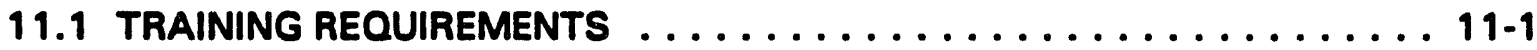

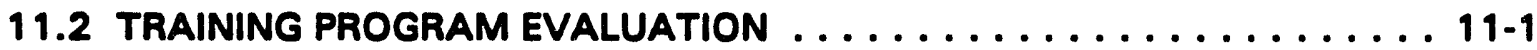

11.3 EMERGENCY PREPAREDNESS COURSES $\ldots \ldots \ldots \ldots \ldots \ldots \ldots \ldots$

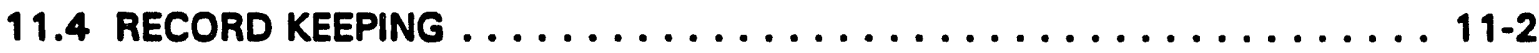

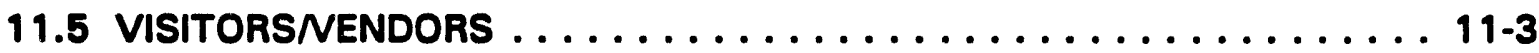

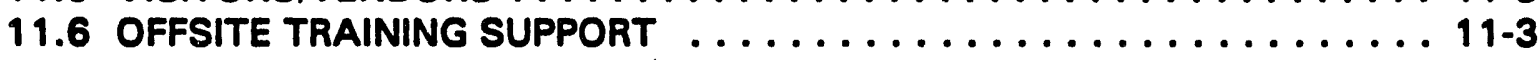

11.7 OFFSITE PERSONNEL TRAINING $\ldots \ldots \ldots \ldots \ldots \ldots \ldots \ldots \ldots \ldots \ldots$

11.8 INSTRUCTOR TRAINING AND QUALIFICATION ............ 11-3

12.0 DRILLS AND EXERCISES $\ldots \ldots \ldots \ldots \ldots \ldots \ldots \ldots \ldots \ldots \ldots \ldots$

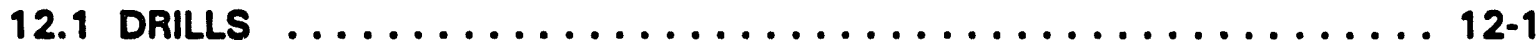

12.1.1 Facility Drills ......................... 12-1

12.1.2 Emergency Center Drills . . . . . . . . . . . . . . . 12-2

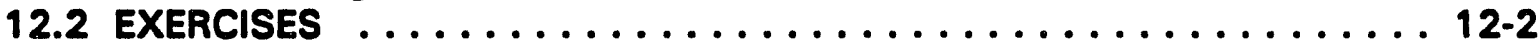

12.2.1 Exercise Development ..................... 12-3

12.2.2 Evaluation and Corrective Action . . . . . . . . . . . . 12-4

12.2.3 Offsite Coordination . . . . . . . . . . . . . . . . . 12-4

13.0 EMERGENCY MANAGEMENT PROGRAM ADMINISTRATION . . . . . . . . . 13-1

13.1 EMERGENCY MANAGEMENT PROGRAM ADMINISTRATOR $\ldots \ldots \ldots$

13.1.1 Emergency Management Functions at the U.S. Department

of Energy, Richland Operations Office . . . . . . . . . . 13-1

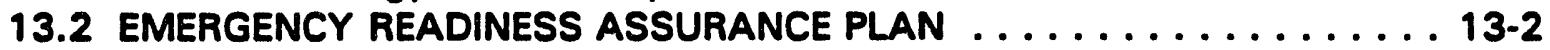

13.3 ASSESSMENTSIAPPRAISALS ................. 13-3 
DOE/RL-94-02, Rev. 0

\section{CONTENTS (cont)}

13.4 DOCUMENT CONTROL . . . . . . . . . . . . . . . . . . . 13-3

13.4.1 Review and Update of the Hanford Site Emergency Response

Plan and U.S. Department of Energy, Richland Operations

Office Implementing Procedures . . . . . . . . . . . . . . 13-4

13.4.2 Review of Agreements . . . . . . . . . . . . . . . . 13-4

13.4.3 Classified Information . . . . . . . . . . . . . . . . . 13-4

13.4.4 Supporting Documents . . . . . . . . . . . . . . . . 13-4

13.4.5 Vital Records ........................ 13-5

13.4.6 Emergency Records . . . . . . . . . . . . . . 13-5

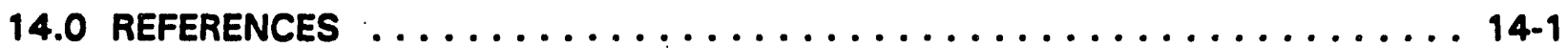

\section{APPENDICES}

A LAW ENFORCEMENT ASSISTANCE PLAN $\ldots \ldots \ldots \ldots \ldots \ldots \ldots \ldots \ldots$

B MEMORANDA OF UNDERSTANDING $\ldots \ldots \ldots \ldots \ldots \ldots \ldots \ldots \ldots \ldots$ 
DOE/RL-94-02, Rev. 0

\section{LIST OF FIGURES}

$1-1$ Hanford Site Map $\ldots \ldots \ldots \ldots \ldots \ldots \ldots \ldots \ldots \ldots \ldots \ldots \ldots$

$1-2$ Hanford Site Emergency Planning Zone . . . . . . . . . . . . . . . . 1-8

2-1 Hanford Site Emergency Response Organization . . . . . . . . . . . . . . 2-6

3-1 Lines of Communication Between Emergency Centers . . . . . . . . . . . . 3-3

5-1 Hanford Site Emergency Planning Zones . . . . . . . . . . . . . . 5-3

6-1 Emergency Notification Form . . . . . . . . . . . . . . . . 6-2

10-1 Hanford Site Emergency Centers . . . . . . . . . . . . . . . . . 10-2

\section{LIST OF TABLES}

$1-1$ Permanent Population Distribution $\ldots \ldots \ldots \ldots \ldots \ldots \ldots \ldots \ldots$

$1-2$ Transient Population Distribution $\ldots \ldots \ldots \ldots \ldots \ldots \ldots \ldots \ldots \ldots$

3-1 Memorandums of Understanding $\ldots \ldots \ldots \ldots \ldots \ldots \ldots \ldots \ldots \ldots \ldots$ 3-11

4-1 Summary of Emergency Classes . . . . . . . . . . . . . . . . . . 4-3

4-2 Hanford Site Emergency Event Classification Criteria . . . . . . . . . . . . . . 4-6

5-1 Hanford Site Emergency Planning Zones . . . . . . . . . . . . . . . 5-2

5-2 Exposure Criteria for Hazardous Materials $\ldots \ldots \ldots \ldots \ldots \ldots \ldots$

6-1 Standard Emergency Signals . . . . . . . . . . . . . . . . . . . . 6-8 


\section{ACRONYMS}

\begin{tabular}{|c|c|}
\hline $\begin{array}{l}\text { AED } \\
\text { AlHA } \\
\text { ALARA } \\
\text { BED } \\
\text { BW } \\
\text { CEDE } \\
\text { CERCLA } \\
\text { DOE } \\
\text { DOE-HO } \\
\text { EACT } \\
\text { EAL } \\
\text { EBS } \\
\text { ECC } \\
\text { ECOIOgY } \\
\text { ECP } \\
\text { EDE } \\
\text { EDF } \\
\text { EMC } \\
\text { EMT } \\
\text { ENS } \\
\text { EOC } \\
\text { EPA } \\
\text { EPCRA } \\
\text { EPZ } \\
\text { ERAP } \\
\text { ERPG } \\
\text { FAA } \\
\text { FBI } \\
\text { FDA } \\
\text { FEMA } \\
\text { FFTF } \\
\text { FMEF } \\
\text { FRERP } \\
\text { FRP } \\
\text { FTCC } \\
\text { HEHF } \\
\text { HSC } \\
\text { ICF KH } \\
\text { IRM } \\
\text { JIC } \\
\text { LFA } \\
\text { MOU } \\
\text { NRC } \\
\text { ONC } \\
\text { PAG }\end{array}$ & $\begin{array}{l}\text { Area Emergency Director } \\
\text { American Industrial Hygienists Association } \\
\text { as low as reasonably achievable } \\
\text { Building Emergency Director } \\
\text { Building Warden } \\
\text { committed effective dose equivalent } \\
\text { Comprehensive Environmental Response, Compensation, and } \\
\text { Liability Act } \\
\text { U.S. Department of Energy } \\
\text { U.S. Department of Energy, Headquarters } \\
\text { Emergency Action and Coordinating Team } \\
\text { Emergency Action Level } \\
\text { Emergency Broadcast System } \\
\text { Emergency Control Center } \\
\text { Washington State Department of Ecology } \\
\text { Event Command Post } \\
\text { effective dose equivalent } \\
\text { Emergency Decontamination Facility } \\
\text { Emergency Management Center } \\
\text { Emergency Medical Technician } \\
\text { Emergency Notification System } \\
\text { Emergency Operations Center } \\
\text { U.S. Environmental Protection Agency } \\
\text { Emergency Planning and Community Right-to-Know Act } \\
\text { emergency planning zone } \\
\text { Emergency Readiness Assurance Plan } \\
\text { Emergency Response Planning Guideline } \\
\text { Federal Aviation Administration } \\
\text { Federal Bureau of Investigation } \\
\text { Food and Drug Administration } \\
\text { Federal Emergency Management Agency } \\
\text { Fast Flux Test Facility } \\
\text { Fuel Materials Examination Facility } \\
\text { Federal Radiological Emergency Response Plan } \\
\text { Federal Response Plan } \\
\text { Field Team Coordination Center } \\
\text { Hanford Environmental Health Foundation } \\
\text { Health Service Centers } \\
\text { ICF Kaiser Hanford Company } \\
\text { Information Resource Management } \\
\text { Joint Information Center } \\
\text { Lead Federal Agency } \\
\text { Memoranda of Understanding } \\
\text { U.S. Nuclear Regulatory Commission } \\
\text { Occurrence Notification Center } \\
\text { Protective Action Guideline }\end{array}$ \\
\hline
\end{tabular}


ACRONYMS (cont)

PAR

PNL

POC

PSO

RAP

QSH

RCRA

RL

SAR

SARA

SAS

SNM

SRG

Supply System

UDAC

USCG

WHC

WNP-2 protective action recommendation

Pacific Northwest Laboratory

Patrol Operations Center

Program Secretarial Officer

Radiological Assistance Program

Quality, Safety, and Health Program Division

Resource Conservation and Recovery Act

U.S. Department of Energy, Richland Operations Office

Safety Analysis Report

Superfund Amendment and Reauthorization Act of 1986

Safeguards and Security

special nuclear material

Scenario Review Group

Washington Public Power Supply System

Unified Dose Assessment Center

U.S. Coast Guard

Westinghouse Hanford Company

Washington Nuclear Project 2 
DOE/RL-94-02, Rev. 0

HANFORD EMERGENCY RESPONSE PLAN

\subsection{INTRODUCTION}

\subsection{PURPOSE}

The Hanford Emergency Response Plan for the U.S. Department of Energy (DOE), Richland Operations Office (RL), incorporates into one document an overview of the emergency management program for the Hanford Site. The program has been developed in accordance with DOE Orders, and state and federal regulations to protect worker and public health and safety and the environment in the event of an emergency at or affecting the Hanford Site.

This plan provides a description of how the Hanford Site will implement the provisions of DOE $\mathbf{5 5 0 0}$ series and other applicable Orders in terms of overall policies and concept of operations. It should be used as the basis, along with DOE Orders, for the development of specific contractor and RL implementing procedures.

\subsection{SCOPE}

The Hanford Emergency Response Plan describes the overall emergency organization, authorities, and responsibilities for response to and mitigation of emergency events involving facilities and activities on the Hanford Site. These events include the full spectrum of operational emergencies, natural phenomena, and safeguard and security emergencies. The plan also describes the authorities, responsibilities, and agreements for response to offsite and near-site facility emergencies that have the potential for detrimentally affecting the health of personnel and safety of operations at the Hanford Site.

The RL and each contractor shall develop and maintain procedures or other documents necessary to implement the emergency program described in the Hanford Emergency Response Plan. Procedures shall contain specific instructions, including response actions, associated precautions and prerequisites, and identification of responsible individuals. For the Hanford Site, these procedures shall include, but are not limited to:

- RL Emergency Procedures: Procedures that delineate the implementation of the RL emergency management team responsibilities; i.e.. Emergency Action and Coordinating Team (EACT), Unified Dose Assessment Center (UDAC) and Field Team Coordination Center (FTCC), and the Joint Information Center (JIC).

- Contractor Emergency Preparedness Procedures and Plans: Procedures to enable the implementation of the responsibilities of the contractor emergency management team. Also, specific facility and organizational plans and procedures for response to, and recovery and restoration from specific emergency conditions at facilities on the Hanford Site. These include building emergency plans and procedures, which are required for all buildings, facilities, and structures that are 
defined as a nuclear or reactor facility, contain reportable quantities of hazardous substances as defined by the Washington State Department of Ecology (Ecology).

In addition to the program for response to and mitigation of emergencies, the plan also provides direction on the activities necessary to ensure emergency preparedness on the Hanford Site such as training, drills, exercises, and assessments. The authority and responsibility for interfaces with offsite organizations responsible for protecting the public and the environment, including those agencies that may provide or request support in the event of an emergency, is also delineated.

The RL responsibility to provide, upon request, radiological advice and assistance to other federal, tribal, state, or local governments under the Radiological Assistance Program (RAP) is defined in the U.S. Department of Energy Region 8 Radiological Assistance Program Plan (DOE/RL 1992; (DRE/RL-92-49).

\subsection{CONCEPT OF OPERATION}

The Hanford Site Emergency Management Program provides the final barrier for ensuring the safety and health of workers and the public, and for protecting property and the environment in the event of an emergency. The emergensy management program prepares the Hanford Site emergency organizations to respond to an emergency in a timely, efficient, and effective manner resulting in improved mitigation of consequences. The Hanford Site Emergency Management Program is developed and maintained to ensure adequate response to a broad range of potential scenarios and to provide the framework for responding to scenarios not specifically considered.

The Hanford Site Emergency Management Program elements are:

- Planning: Includes the development and preparation of emergency plans and procedures and the identification of necessary personnel and resources to provide an effective response.

- Preparedness: Includes the training of personnel; acquisition and maintenance of resources; and exercising of the plans, procedures, personnel, and resources essential for emergency response.

- Response: Represents the implementation of the planning and preparedness during an emergency, and involves the effactive decisions, actions, and application of resources that must be accomplished to mitigate consequences and recover from an emergency.

\subsubsection{Hanford Site Emergency Management Program Basis}

The Hanford Site Emergency Management Program is based on, and is commensurate with, the hazards and consequences associated with the facilities and activities on the Hanford Site, and offsite facilities that may impact the Site. 
Hazards assessments provide the technical basis for the emergency management program. The extent of planning and preparedness directly corresponds to the type and scope of hazards present and the potential consequences of events. Hazards assessments prepared for Hanford Site hazardous facilities include identification of hazards and targets unique to a facility, analysis of potential events, and evaluation of potential event consequences. While not every conceivable situation will be analyzed, the hazards assessments will provide the framework for response planning for virtually any emergency. Hazards assessments are discussed in Section 4.0 of this plan.

Using the accident scenarios and consequences identified in a facility hazards assessment, the observable methods of detecting or recognizing an emergency can be identified. These indicators, called Emergency Actions Levels (EAL) are used to determine the emergency class. The emergency class is used to trigger specified, preplanned responses and protective actions. Emergency classes and EALs are described in Section 4.0 of this plan.

For each emergency class there shall be predetermined recommended actions. These actions shall include those steps necessary to protect workers, equipment, and the environment. They shall also include recommended actions for the protection of offsite populations. The Hanford Site emergency response organizations shall be formed, trained, and tested to ensure the recognition and classification of emergencies, and the implementation of protective actions. This is described further in Section $\mathbf{5 . 0}$ of this plan.

\subsubsection{Hanford Site Emergency Response Roles}

The Hanford Site emergency management teams will provide management, direction and assistance to response activities. Contractor emergency management teams are responsible for the mitigative and corrective actions necessary to resolve the problem; protect workers, the public, and the environment; and return the facility to a safe condition. The RL emergency management team shall provide guidance and oversee the contractor's response actions; interface with offsite agencies, including the U.S. Department of Energy. Headquarters (DOE-HQ) emergency management team; and provide support to offsite agencies as requested.

\subsection{SITE DESCRIPTION}

\subsubsection{Overviow Site Description}

The 1,456-square-kilometer (560-square-mile) Hanford Site was originally acquired by the federal government in 1943 for the construction and operation of facilities to produce plutonium that was used to help end the Second World War. In 1989 the Hanford Site's mission changed from one of national defense production to waste management, environmental restoration, and technology development.

The Site contains several types of complex facilities, including retireo nuclear reactors, chemical processing facilities, nuclear waste storage tanks, and research laboratories. There 
are more than 1,000 buildings on Site, and an infrastructure of utilities and transportation necessary to support an operation employing approximately 18,000 workers.

1.4.1.1 Hanford Site Facillties/Activities. The major facilities and activities on the Hanford Site, that are DOE-owned and contractor-operated, are grouped together in these major areas:

- 100 Areas: The 100 Areas are located along the Columbia River in the northern portion of the Hanford Site. These areas contain eight retired plutonium production reactors and the dual purpose N-Reactor, which was shutdown in 1991. These facilities are being prepared for permanent disposal. Worker population is approximately 500 .

- 200 East and 200 West Areas: These areas lie on a plateau near the center of the Hanford Site, some 40 kilometers (25 miles) north of Richland, Washingtun. The 200 Areas are dedicated to waste management activities, laboratory support, waste characterization, and nuclear material processing. Worker population is approximately 5,200.

- 300 Area: The 300 Area is approximately 8 kilometers (5 miles) north of Richland, Washington. Major activities in the 300 Area are nuclear research and development. Worker population is approximately $2,500$.

- 400 Area: This area, about 15 kilometers (9 miles) north of Richland, Washington, contains the Fast Flux Test Facility (FFTF) (in transition to shutdown), the Fuel Materials Examination Facility (FMEF), and related support facilities involved in the liquid metal reactor program. Worker population is approximately 720.

- 600 Area: The 600 Area includes all of the Hanford Site not occupied by the other listed areas. L.and uses include the 312-square-kilometer (120-square-mile) Arid Lands Ecology Reserve, a U.S. Fish and Wildlife Refuge, and a recreational game site leased to the Washington State Department of Game. Worker population is approximately 530 .

The Site also contains two facilities that are not owned and/or operated by RL and its contractors:

- A publicly owned commercial nuclear power plant, Washington Nuclear Power Plant No. 2 (WNP-2), operated by the Washington Public Power Supply System (Supply System) on lands leased from the federal government on the eastern side of the Site, near the Columbia River and about 9 miles north of Richland. This facility is operated in accordance with U.S. Nuclear Regulatory Commission (NRC) licensing requirements and rules.

- A low-level radioactive waste disposal site located near the 200 Areas, on land that the state of Washington has leased from the federal government. This facility is commercially operated by the U.S. Ecology Company in accordance with state and federal licenses and permits. 
The RL and contractors also lease facilities off the Hanford Site in the cities of Richland and Kennewick. These areas, designated as the 1100,3000 , and 700 Areas, contain Hanford . Site-related office and warehouse facilities that could not generate an Alert level or higher emergency.

1.4.1.2 Hazards. Activities at the Hanford Site involve both radiological and nonradiological hazardous materials. Major hazardous materials emergencies are associated with the potential for fire, explosion, or dispersion of radiological or toxic chemicals.

A significant hazard requiring emergency planning on the Hanford Site stems from the presence of large quantities of radioactive materials from the various separations, waste storage, research, and previous production and manufacturing materials. These materials, although contained, could affect worker and public health and the environment in the event of dispersion during a major accident.

In addition to radiological hazards, large quantities of various nonradiological hazardous materials are stored and used in chemical processing and other operations at the Hanford Site. Hazardous materials are routinely transported by truck and rail to and around the Site and are stored at various onsite locations. State Route 240, a main public highway that runs through the Site, is used for transporting a wide range of chemicals, including agricultural chemicals to farms and orchards in the surrounding area.

Typically, hazardous materials of concern for emergency planning purposes include petrochemicals, explosives, toxic chemicals and chemical products, and fuel gases le.g.. propane and butane). Hazardous chemicals of particular concern are those with the potential for forming large, toxic airborne clouds that may travel long distances before dispersing. These chemicals include ammonia, chlorine, hydrogen fluoride, liquified petroleum gas, fuming acids, and others.

For purposes of emergency planning, facilities on the Hanford Site are described as either hazardous or nonhazardous. Hazardous facilites are those that could generate an Alert lovel or higher emergency.

1.4.1.3 Contractors. The Hanford Site contractors, responsible in their respective capacities for the operation of the federal facilities, include:

- Westinghouse Hanford Company (Westinghouse Hanford): The operations and maintenance contractor which operates DOE facilities and manages Site support services, such as security, fire protection, construction and architect/engineering services. The major construction services contractor, ICF Kaiser Hanford Company (ICF KH), reports to WHC.

- Pacific Northwest Laboratory (PNL): Operates DOE's Hanford Site research and development laboratory, and performs environmental monitoring.

- Hanford Environmental Health Foundation (HEHF): Provides occupational health services to Hanford Site employees. 


\subsubsection{Physical Attributes of the Hanford Site}

The Hanford Site is located in the southeastern area of the State of Washington. The Site covers approximately 1,456 square kilometers (560 square miles) located in Benton, Franklin, and Grant Counties just northwest of the cities of Richland, Kennewick, and Pasco (Tri-Cities) (see Figure 1-1).

The Columbia River runs across the northern half of the Site, then flows south, across the eastern side of the Site. The Yakima River borders part of the southern boundary of the Site and joins the Columbia River below the city of Richland. A worse case flood of the Columbia River or catastrophic breach of Grand Coulee Dam could impact parts of the 100 and 300 Areas, but the central portion of the Site would remain unaffected.

The Hanford Site and surrounding area has a semiarid climate with a sparse covering of vegetation. The terrain of the central and eastern parts of the Site is relatively flat. Rattlesnake Mountain, the Yakima Ridge, and the Umtanum Ridge continue onto the Site from the west and form the southwestern and western boundary. Two small east-west ridges, Gable Butte and Gable Mountain, rise above the plateau of the central part of the Site. It is an area of low seismicity in which moderate level earthquakes can occur.

The area has moderate winters and hot summers. Severe thunderstorms are rare, although the Site is vulnerable to lightning strikes causing grass fires. Formation of a severe tornado is highly unlikely.

Primary land uses of the surrounding areas are irrigated and nonirrigated farming, residential living, and state and federal controlled lands.

Due to the size of the Hanford Site, there may be differences in the specific physical attributes in the vicinity of each hazardous facility. Detailed discussions and analysis of the local geography, geology, seismology, meteorology, and hydrology in the area of each hazardous facility are contained in Safety Analysis Reports (SARs).

1.4.2.1 Population. The permanent population within the 50 mile ingestion exposure emergency planning zone (EPZ) of the Hanford Site, which is centered on WNP-2, is approximately 270,000 (Figure 1-2). Table 1-1 shows the permanent population distribution. The maximum transient population within the ingestion EPZ, including Hanford Site workers, offsite workers, and recreationists, is approximately 17,000. Table 1-2 shows the transient population.

Plume EPZ populations for Hanford Site EPZs are as follows:

- 100 Area: Small portion of a sparsely populated area of southern Grant County. Permanent and transient population are as yet undetermined pending geographic boundary development. There are no special populations.

- 200 Areas: Small portion of a sparsely populated area of northwestern Benton County. Permanent and transient populations are as yet undetermined pending geographic boundary development. There are no special populations. 
DOE/RL-94-02, Rev. 0

Figure 1-1. Hanford Site Map.

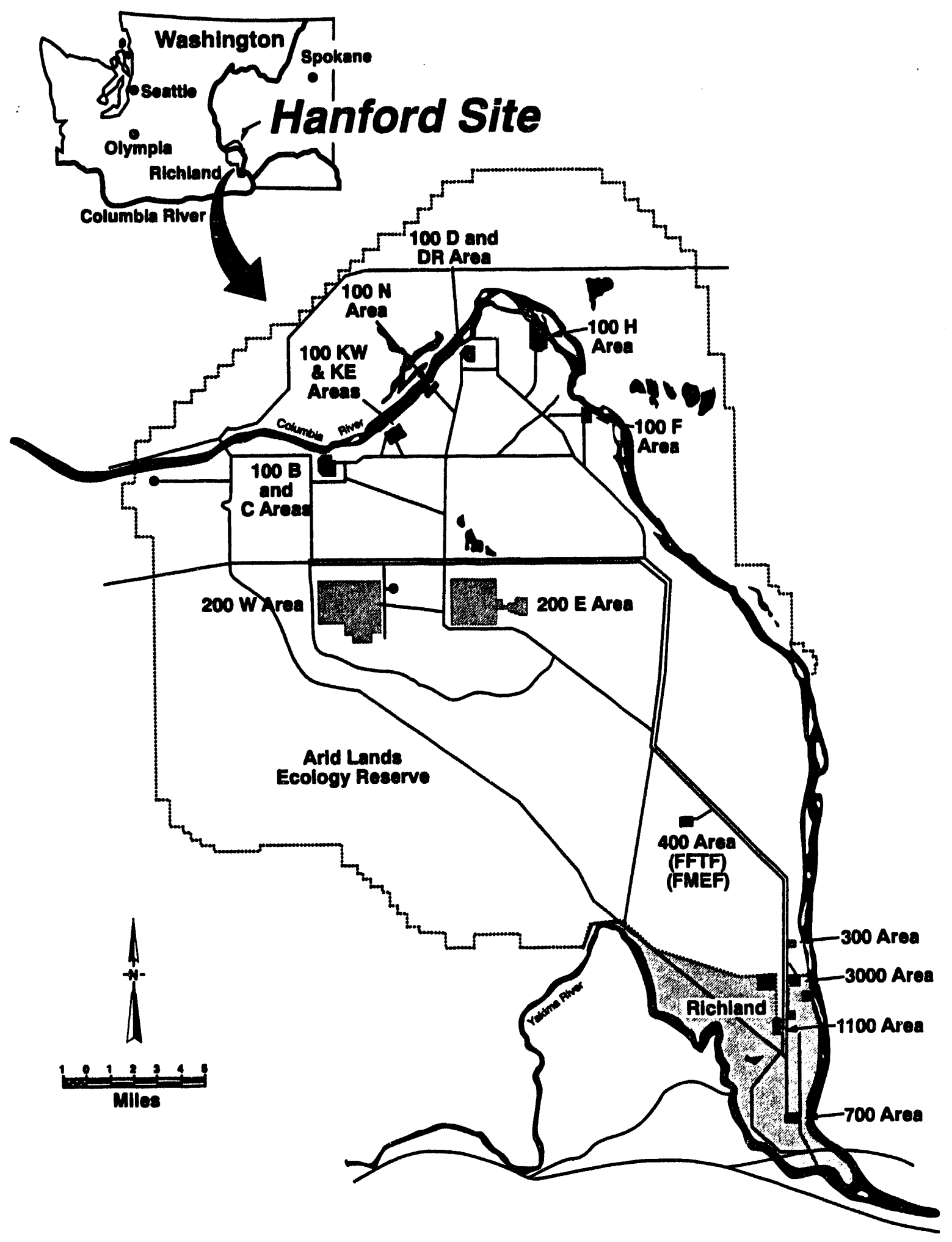


DOE/RL-94-02, Rev. 0

Figure 1-2. Hanford Site Emergency Planning Zones.

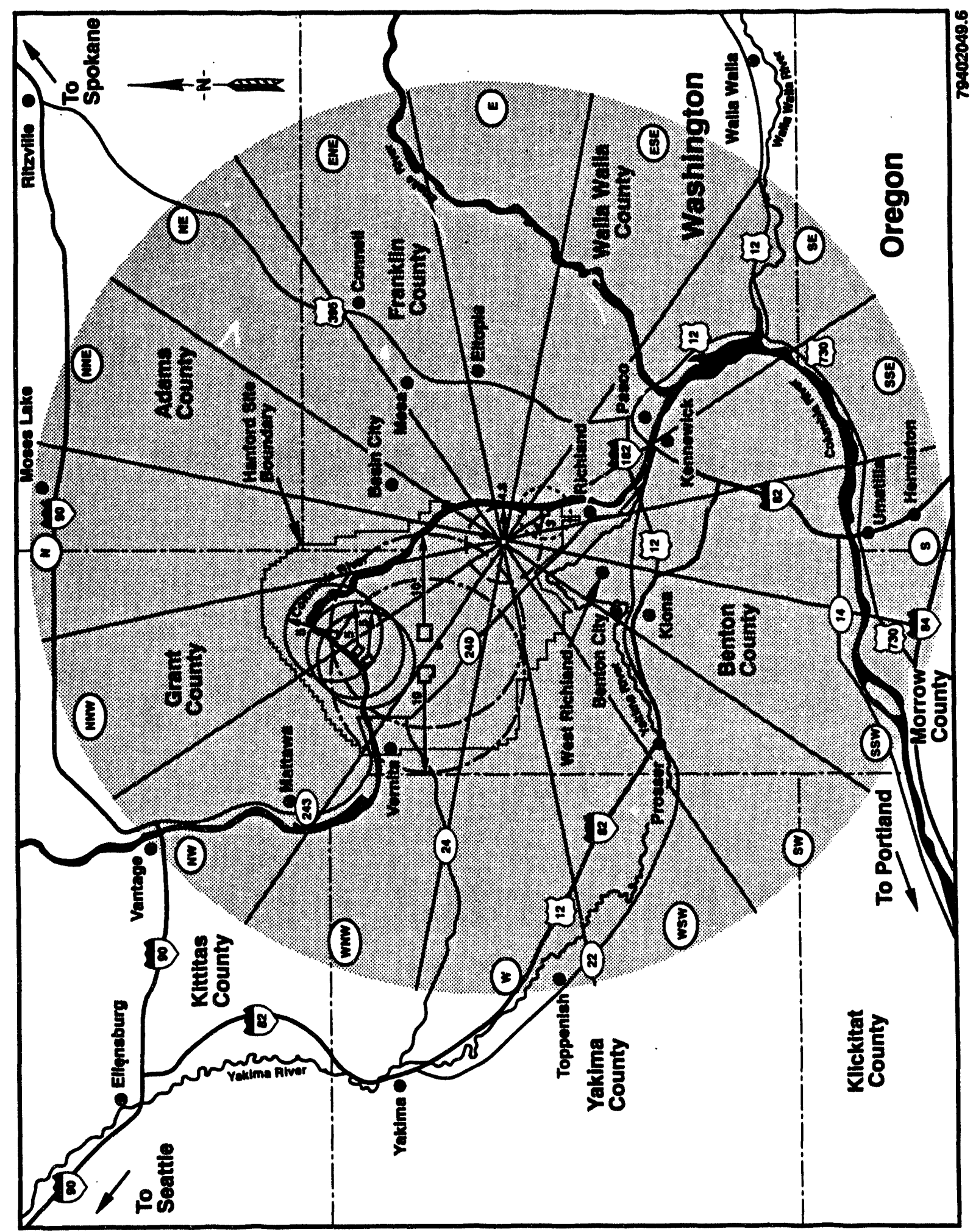


Table 1-1. Permanent Population Distribution.

\begin{tabular}{|c|c|c|c|c|c|c|c|c|c|c|c|c|c|c|c|c|c|c|c|}
\hline Milo & 1 & 2 & 3 & 4 & 5 & 0 & 7 & 8 & 9 & 10 & 15 & 20 & 26 & 30 & 35 & 40 & 46 & 80 & Tosel \\
\hline Sector $N$ & & & & & & & & 3 & 7 & 14 & 138 & 184 & 075 & 820 & 454 & 620 & 2,804 & 14,968 & 20.708 \\
\hline NNE & & & & & & 8 & 10 & 23 & 32 & 53 & 130| & 182 & 481 & 5,278 & 732 & 2.460 & 423 & 470 & 10,304 \\
\hline NE & & & & 4 & 13 & 27 & 20 & 67) & 29 & 70 & 180 & 233 & 430 & 1.585 & 365 & 285 & 130 & 780 & 4.210 \\
\hline ENE & & & & 8 & 20 & 32 & 63 & 18 & 33 & 55 & 184 & 608 & 280 & 1,421 & 80 & 331 & 100 & 113 & 3,373 \\
\hline E & & & & 2 & 18 & 38 & 41 & 42 & 27 & 54) & 182 & 269 & 88 & 83 & 68 & 89 & 114 & 127 & 1.204 \\
\hline ESE & & & & 5 & 8 & 40 & 48 & 72 & 63 & 65 & 80 & 112 & 69 & 84 & 77 & 80 & 280 & 684 & 1,687 \\
\hline SE & & & & & 5 & 14 & 84 & 50 & 84 & 108 & 647 & 3,008 & 2,702 & 3,370 & 216 & 248 & 884 & 1,100 & 13,184 \\
\hline SSE & & & & & & & 9 & 33 & 32 & 14 & 7,688 & 41,580 & 22,902 & 1.214 & 275 & 317 & 821 & 818 & 75.714 \\
\hline & & & & & & & & & & 67) & 25,922 & 3,021 & 84 & 103 & 567 & 4,113 & 2,050 & 14,480 & 50,407 \\
\hline SSW & & & & & & & & & 120 & 248 & 1.288 & 294 & 393 & 482 & 42 & 214 & 184 & 2,446 & 8.702 \\
\hline $\mathbf{s w}$ & & & & & & & & 4 & 3 & & 494 & 2,612 & 875 & 5,280 & 218 & 254 & 189 & 222 & 10,172 \\
\hline Wsw & & & & & & & & & & & 386 & 864 & 732 & 884 & 4,478 & 17,383 & 382 & 427 & 25,250 \\
\hline$w$ & & & & & & & & & & & & & 530 & 655 & 1,060 & 1,818 & 0,077 & 12,438 & 23,284 \\
\hline WNW & & & & & & & & & & & & & 83 & 102 & 648 & 760 & 822 & 920 & 3,320 \\
\hline $\mathbf{N W}$ & & & & & & & & & & & & & 18 & 22 & 187 & 510 & 383 & 428 & 1,655 \\
\hline NNW & & & & & & & & & & & & & 82 & 100 & 318 & 1.257 & 251) & 281 & 2,280 \\
\hline Totel & & & & 18 & 64 & 100 & 275 & 303 & 420 & 737 & 37.141 & 53,287 & 30,486 & 21.515 & 10,377 & 30,758 & 18,084 & 50.730 & 252,350 \\
\hline $\begin{array}{r}\text { Accumulated } \\
\text { Total }\end{array}$ & 0 & 0 & o) & 18 & 83 & 243 & 518 & 821 & 1.241 & 1,878 & 30.110 & 82,400 & 122,882 & 144,407 & 154,784 & 185,542 & 201,020 & 252,350 & 504,712 \\
\hline
\end{tabular}

Source: Wechington Public Power Supply Syatem, July 1891. 
Table 1-2. Transient Population Distribution.

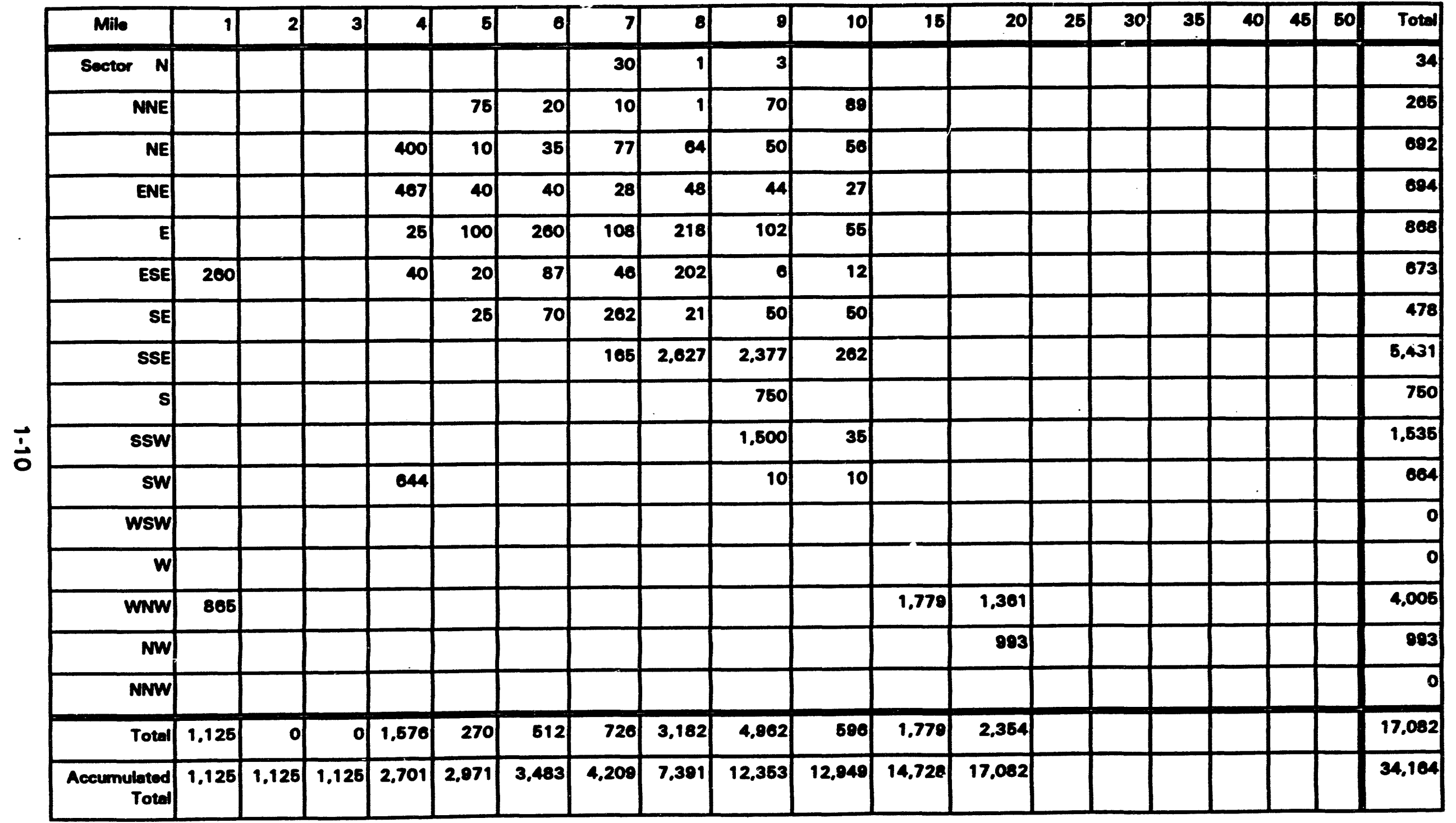

Source: Wechington Public Power Supply System, July 1981. 
DOE/RL-94-02, Rev. 0

- 300 Area: Portions of western Franklin County and north Richland. Permanent, transient, and special populations are as yet undetermined pending geographic boundary development.

- 400 Area: Portions of Franklin and Benton Counties. Permanent, transient and special populations are as yet undetermined pending geographic boundary development.

The EPZs are discussed further in Section 5.0.

1.4.2.2 Transportation System. Hundreds of miles of roads are maintained on the Hanford Site. State Routes 240 and 24 and Site roads are used by many types of vehicles including commercial trucks and private vehicles.

In addition to private vehicles, government vans, cars, and buses are available to provide transportation in the event of an emergency.

The Site railroad system consists of 169 kilometers (105 miles) of track used to transport commercial and nuclear material.

The Richland Airport, nearest to the Hanford Site, is a small, general utility airport. The Tri-Cities Airport (Pasco) is used by regional carriers.

The section of the Columbia River that flows near the Hanford Site is used mainly by recreationists. Barge traffic does not operate on the stretch of the river which goes through the Site. 
DOE/RL-94-02, Rev. 0

This paje intentionally left blank. 


\subsection{EMERGENCY RESPONSE ORGANIZATION (INTERNAL)}

The mission of the Hanford Site emergency response organization is to ensure that, in the event of an emergency, actions will be taken to prevent or minimize impacts to workers, the public, Site, facilities, and the environment. The emergency response organization shall be structured and staffed with adequate, trained personnel to enable the most timely and effective response possible, while meeting the requirements as set forth in the DOE 5500 series Orders and other applicable state and federal regulations.

\subsection{ORGANIZATION STRUCTURE}

While RL maintains the option to assume overall management, direction, and control of any Hanford Site emergency, the Hanford Site emergency response organization has been developed to allow contractors to continue their management and operational roles in the event of an emergency.

The Hanford Site emergency response organization has two components. The first component consists of contractor response personnel and emergency management teams with the responsibility for response to, and mitigation of, an emergency on the Site. The second component consists of the RL emergency management team that has the responsibility to oversee the onsite response, assess the offsite impacts, and interface with offsite agencies and the public.

\subsubsection{Hanford Site Contractors}

Hanford Site contractors operate facilities and provide Site services for RL. Contractors shall coordinate with one another to ensure development of an emergency response and management capability which meets the mission of the Hanford Site emergency response organization.

2.1.1.1 Event Contractor. The contractor that maintains responsibility for the facility or activity with the emergency is designated as the Event Contractor. The Event Contractor responsibilities include:

- Prompt and accurate categorizing of all occurrences in accordance with DOE Order 5000.3B (DOE 1993).

- Initially classifying the emergency

- Mitigating the emergency situation

- Initiating actions to protect workers within their geographic area of responsibility

- Notifying the Occurrence Notification Center (ONC) to make onsite and initial offsite notifications 
- Requesting support from nonevent contractors, as necessary

- Establishing an Event Command Post (ECP)

- Providing emergency management team members to the Area Emergency Control Centers (ECCs)

- Providing a senior management representative to the Emergency Management Center (EMC)

- Providing event status information to the Area ECCs

- Providing the manager and technical spokesperson for the JIC

- Providing a senior management representative to the RL-ECC to provide liaison between the event scene and RL.

Other contractors shall provide support to the Event Contractor for actions related to the services they provide on Site, such as notifications, fire, medical, or security services.

2.1.1.2 WHC Company. In addition to Event Contractor responsibilities for the Hanford Site facilities it operates, WHC is the Site operations and maintenance contractor. As such, Westinghouse Hanford emergency responsibilities include:

- Fire protection, rescue, and emergency medical services provided by the Hanford Fire Department

- Site security, access control, and emergency service call answering and dispatching provided through the Hanford Patrol

- Emergency communications, including onsite and initial offsite notifications provided by the ONC

- Operation and staffing of Area ECCs and the EMC

- Staffing of an emergency duty officer position to provide 24-hour emergency support to the contractor emergency response organization

- Management and staffing of the UDAC/FTCC

- Staff support to the RL-ECC

- Staffing of the JIC

- Onsite radiation monitoring

- Laboratory services. 
Under contract to WHC, ICF KH responsibilities include:

- Transportation

- Services in support of re-entry and recovery operations, such as decontamination, engineering, equipment maintenance, utilities, procurement, and waste disposal.

Under contract to WHC. Information Resource Management (IRM) responsibilities include:

- Radio

- Tolecommunications

- Computer

- Audio-visual services.

2.1.1.3 Pacific Northwest Laboratory. In addition to Event Contractor responsibilities for the Hanford Site facilities it operates, the PNL is the research and development contractor for the Site. In the event of an emergency, PNL provides:

- Weather information from the Hanford Site meteorology station

- Environmental radiation sampling and measurement

- Health physics technical support

- Control of nonmedical radiological operations of the Emergency Decontamination Facility (EDF)

- Evaluation of radiological doses to personnel in the event of a criticality emergency

- Staff for the 300 Area ECC, the EMC, the UDAC/FTCC, and the JIC.

2.1.1.4 Hanford Environmental Health Foundation. The HEHF provides occupational health services. Emergency services provided by HEHF include:

- Emergency medical care and consultation

- On-scene emergency nursing services, as appropriate

- Medical staffing and operation of the EDF

- Hostage negotiation support

- Coordination with and support to community medical services

- Nonradiological industrial hygiene monitoring and analysis

- Nonradiological hazard evaluation support to the UDAC/FTCC

- Nonradiological field monitoring teams

- Staff for the EMC

- Technical support to the JIC. 


\subsubsection{U.S. Department of Enargy. Richland Oparations Office}

2.1.2.1 RL Manager. The RL Manager has the ultimate responsibility and authority for all Hanford Site emergency response activities and ensuring that offective management is provided for response to emergencies. The RL Manager is also responsible for overseeing the performance of all onsite activities necessary to place the Site in a safe condition and to minimize or terminate uncontrolled releases of hazardous materials. The RL Manager is also responsible for interfaces with offsite agencies and the public.

The RL Manager shall ensure fulfillment of his or her responsibilities through direction of the EACT and RL Representatives assigned to other onsite and offsite emergency centers. The responsibilities and staffing of the EACT is described in Section 2.2.4.

2.1.2.2 RL Senior Management. As designated by the RL Manager, senior management personnel or their designees shall fill the following emergency response organization positions:

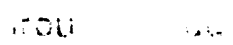

$\therefore$

- Members of the EACT as described in Section 2.2.6.1

- Representative to the UDAC

- Representatives to the Area ECCs

- Representatives to state and county Emergency Operation Centers (EOCs)

- Spokesperson in the JIC

- Liaisons to federal assets

- Representative to DOE-HO, as requested.

2.1.2.3 Facillty Representatives. The RL Facility Representéives are responsible for providing overview of event scene operations. The Facility Representative reports to the RL Area ECC Representative.

2.1.2.4 RL Chief Counsel. The Chief Counsel is responsible for advising the EACT Director regarding all legal matters associated with the emergency, using all required legal resources, and administering the contractual affairs and the legal agreements required by the emergency

2.1.2.5 Chief Financial Officer. The Chief Financial Officer is responsible for the following:

- Reviewing the current budget and reallocating available funds, if required

- Reconstructing financial status as of the date of an emergency

- Administering the emergency account and payroll activities

- Managing all matters related to the payment of claims under nuclear liability insurance coverage

- Arranging payment for, or otherwise resolving, expenses incurred by DOE activities associated with implementing the Emergency Planning. Preparedness, and Response Program 
- Arranging for emergency travel and providing subsistence to personnel from the RL in responding to emergency assistance.

2.1.2.6 Director, Procurement Division. The Procurement Division Director is responsible for procuring all required supplies and services.

2.1.2.7 Director, Site Infrastructure Division. The Site Infrastructure Division Director is responsible for:

- Coordinating power distribution in the event of a power failure

- Reallocating office space, if required

- Coordinating all communications to include interfacing with the U.S. West Telephone Company to implement the emergency communications plan

- Ensuring that vital records, are available and accessible.

2.1.2.8 Director, Human Resources Division. The Human Resources Division Director is responsible for supplying all additional manpower required during the emergency.

2.1.2.9 Director, Project Management Division. The Project Management Division Director is responsible for:

- Coordinating the combined efforts of the nuclear, mechanical, electrical, and civil engineers in order to provide technical design information for special tools, equipment, shielding, storage facilities, and other devices that may be essential during the emergency

- Assessing the extent of structural damage to DOE facilities

- Providing liaison with onsite and offsite architectural/engineering and construction contractors that may be called for assistance during the emergency.

\subsection{EMERGENCY DIRECTION AND CONTROL}

There are four levels in the emergency response organization with emergency direction and control responsibilities: The event scene, the Area ECC, the EMC, and the EACT. The emergency response organization is depicted on Figure 2-1.

\subsubsection{Building Emergency Organization}

2.2.1.1 Nonhazardous Faclities. The building emergency organization in nonhazardous facilities is responsible for emergency response at their facility. The building organization shall assign a Building Warden (BW)/Building Emergency Director (BED) who shall direct an 
DOE/RL-94-02, Rev. 0

Figure 2-1. Hanford Site Emergency Response Organization.

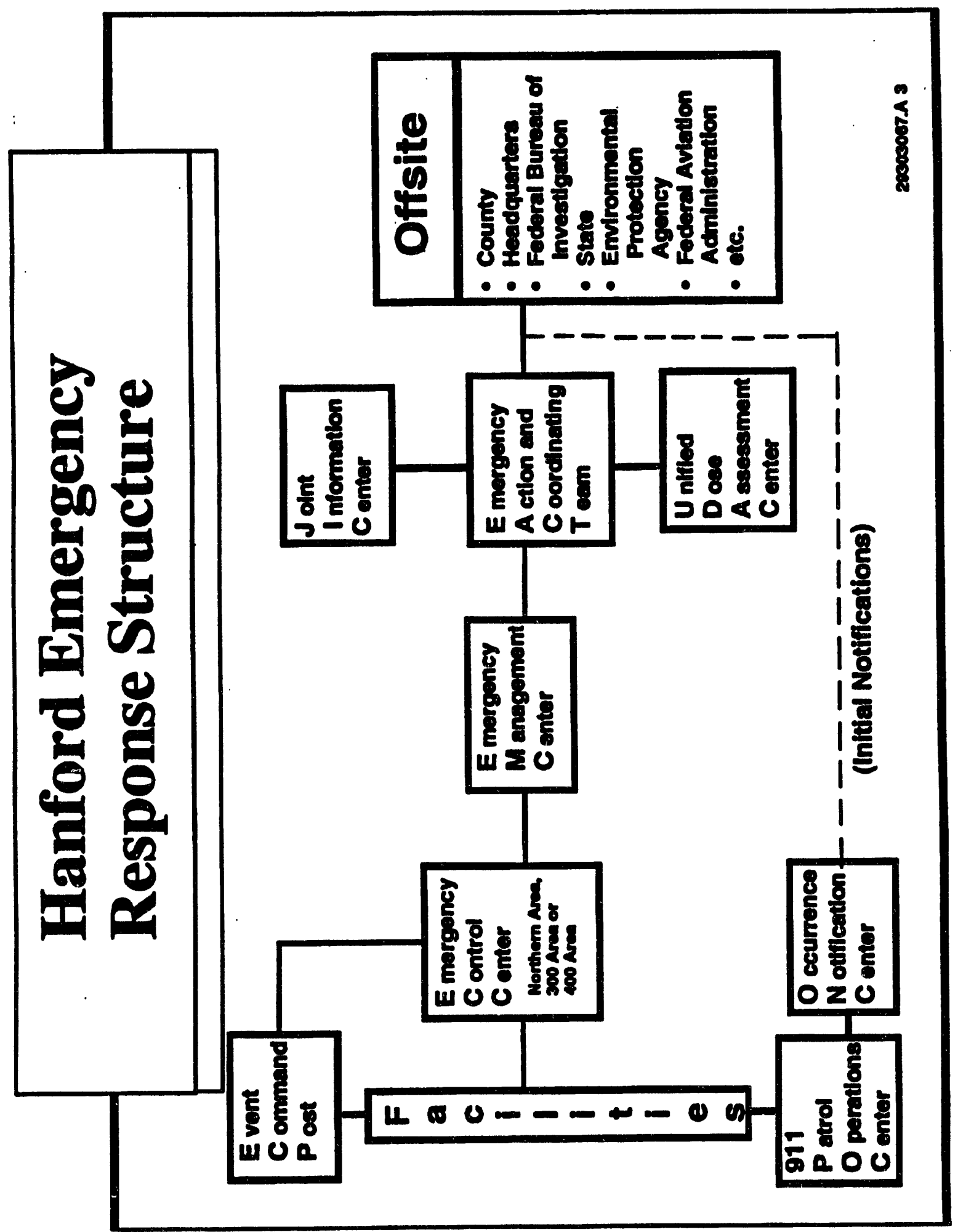


emergency organization made up of individuals within the building who will assist in the protection of personnal, and property. Responsibilities of the building emergency organization shall include:

- Assignment and training of the building emergency organization

- Notifying building occupants of protective action recommendations (PARs)

- Maintaining the facility emergency response information boards/building emergency procedures

- Mitigating emergencies within the assigned building.

2.2.1.2 Hazardous Facllties. The building emergency organization in hazardous facilities is responsible for emergency response at the event scene. The building organization shall assign a BED who shall direct an emergency organization made up of individuals within the building who will assist in the protection of personnel, property, and the environment. The positions and responsibilities shall be detailed in specific building emergency plans. The content, distribution and organizational approval of the building emergency plan shall be determined by the contractor emergency preparedness organization. The responsibilities of the BED shall include:

- Assignment and training of the building emergency organization

- Reviewing and revising the building emergency plan at least every 15 months

- Determining the appropriate emergency event classification and providing emergency classification information to the ONC in accordance with established procedures

- Directing the ONC to initiate center activations, notifications, and predetermined offsite PARs in accordance with established procedures

- Implement predetermined onsite protective actions

- Establishing an ECP

- Mitigating emergencies within the assigned building.

\subsubsection{Event Command Post}

An ECP shall be established near the event scene to coordinate the actions of emergency response personnel from different organizations responding to the event scene. The Event Commander, who shall be either the BED, Fire Commander. WHC Emergency Duty Officer, or Patrol Shift Commander, shall have command of all emergency response efforts until an Area ECC is activated. After activation, the Area ECC will assume responsibility for all actions away from the event scene, with the ECP maintaining responsibility for operational response at the event scene. The Area ECC shall inform the ECP of actions prior to 
implementing actions away from the event scene. Organizations supporting the Event Commander retain responsibility for managing their technical operations and personnel.

2.2.2.1 Hanford Fire Department. The Hanford Fire Department Operations Division is the emergency response element of the department and is responsible for actions to confine and control the full range of potential fire emergencies to include radiological, structural, and wildland fire emergencies within Hanford Site boundaries.

The Hanford Fire Department is the designated incident command agency for control of all hazardous materials incidents on the Hanford Site and, as such, controls the fire, hazardous materials and/or personnel rescue response activities associated with an emergency.

The Hanford Fire Department also coordinates and provides emergency medical services on the Hanford Site.

2.2.2.2 Hanford Patrol. The Hanford Patrol provides security services, including activation of crash alarm systems and area sirens, coordination of the movement of emergency personnel through security gates, evacuation assistance, barricade establishment where needed, and making necessary notifications through the Hanford Patrol Operations Center (POC). Additional law enforcement is available through agreements with local and federal agencies at the request of RL.

During an RL-declared security event, the Hanford Patrol establishes a forward command post, and directs response and control of the security event through direction from the RL-EACT. The forward command post is established at a location that provides communications, protection of the team from event activities, and the capability to monitor the activities associated with the event. Functions performed at the forward command post include:

1. Directing Hanford Patrol forces at the event scene

2. Coordinating Hanford Patrol resources

3. Communications with the RL-ECC security representative for event status and direction

4. Hostage negotiation activities.

\subsubsection{Area Emergency Control Centers}

Area ECCs shall operate to assist the building emergency organizations/Event Commander in mitigating emergency events that involve or impact area facilities. There are three area ECCs on the Hanford Site.

The Northern Area ECC is responsible for:

- All 100 Area facilities within the 100B, C, D, DR, F, H, KE, KW, and N Areas 
DOE/RL-94-02, Rev. 0

- All 200 East Area and 200 West Area facilities

- All of the 600 Area north of the Wye Barricade between the Columbia River and State Route 240.

The 300 Area ECC is responsible for:

- All 300 Area facilities

- All of the 600 Area, south of the Wye Barricade.

The 400 Area ECC is responsible for all 400 Area facilities.

The respective Area ECC shall be activated upon classification of an alert level or higher emergeney or when determined to be needed to support a building emergency organization.

2.2.3.1 Area ECC Staffing and Responsibilities. The Area Emergency Director (AED) directs the area emergency response organization and Area ECC operations. He or she has the lead responsibility for supporting the BED in mitigation of emergencies within his or her area of responsibility. The AED is also responsible to determine and implement onsite protective actions needed within his or her area of responsibility, beyond those already implemented by the BED. If necessary, the AED shall provide recommendations to the EMC for onsite protective actions for areas beyond the Area ECC responsibility.

Other responsibilities of the Area ECCs include:

- Establishing and maintaining contact with the event scene

- Coordinating safety resources, as required

- Coordinating Site services support such as utilities, transportation etc.

- Coordinating evacuations of area personnel, as required

- Interfacing with contractor management, as required

- Interfacing with UDAC/FTCC

- Interfacing with, and recommending emergency reclassification or termination to, the EMC.

Staff positions and responsibilities for each Area ECC shall be identified in contractor implementing procedures. 


\subsubsection{Emergency Management Center}

The EMC is the location from which the contractor emergency management team provides support to the area response and manages Sitewide response and resources. The EMC is located in the 1170 Building.

The EMC shall be activated when classification of an alert level or higher emergency is established or when otherwise requested by RL or contractor management.

2.2.4.1 EMC Staffing and Responsibilities. The EMC Director is a senior WHC Manager and the EMC Assistant Director is a senior manager from the event contractor. The EMC Diroctor is responsible for directing operation of the center, directing implementation of appropriate onsite protective actions, and recommending event reclassification to RL. Other staff positions are filled by personnel from functional areas as the position requires. Staff positions and responsibilities for the EMC shall be identified in specific EMC operation procedures.

The EMC staff provides the following functions after the EMC is activated:

- Interfaces with RL on event status and planned actions

- Interfaces with the Area ECC

- Recommends emergency reclassification or termination to RL

- Monitors Sitewide emergency response activities

- Provides resources, where needed, for stabilization and recovery

- Evaluates potential hazards and Site-response needs

- Directs Sitewide safety related support

- Oversees Sitewide activities of the Hanford Patrol, Hanford Fire Department, and Security for evacuation coordination

- Coordinates Site resources

- Obtains technical and sitewide support, as required

- Interfaces with the JIC, as required

- Coordinates with the Area ECC, EACT, and UDAC personnel to obtain timely dose projections and PARs

- Provides interface for all Hanford Site contractors representatives, as required. 


\subsubsection{Occurrence Notffication Center}

The ONC is a 24-hour operational facility equipped to communicate information regarding occurrences at, or affecting, the Hanford Site to Site contractors, RL, and state and local emergency management organizations. The ONC is responsible for:

- Activating the Hanford Site emergency response organization vis the automated Emergency Notification System (ENS)

- Providing initial notifications, via the automated ENS, to Grant County residents within the 100 Area EPZ

- Providing initial notifications to DOE-HQ, and state and local emergency management agencies prior to activation of the RL-ECC.

The ONC responsibilities are covered further in Section 6.0. Specific operational desk instructions shall be maintained by the ONC.

\subsubsection{RL Emergency Control Conter}

The RL-ECC consists of the EACT, the UDAC/FTCC, and the JIC. The RL-ECC operates under the direction of the RL Manager, who acts as the EACT Director. The UDAC/FTCC and JIC each have managers who report directly to EACT staff.

The RL-ECC shall be activated at classification of an emergency or as directed by the RL Manager or his designee and shall be operational within one hour.

Procedures for the activation and operation of the EACT, UDAC/FTCC, and JIC, including staffing and responsibilities, are contained in DOE-0223, U.S. Department of Energy, Richland Operations Office Emergency Plan Implementing Procedures (DOE 1992a).

2.2.6.1 RL Emergency Action and Coordinating Team. The EACT is the RL emergency management team made up of RL and Hanford Site contractor personnel that manages all offsite interfaces and overviews the onsite emergency management.

During RL-declared security events, RL. is responsible for all decisions that address mitigation of the security event. This involves direction and control of Hanford Site security and patrol forces, and coordination of facility response. However, the Federal Bureau of Investigation (FBI) may exercise the option to take command of security events involving the violation of the Atomic Energy Act of 1954 or other federal statutes. Associated response by contractor personnel for personnel and operational safety rests with the Area ECC and/or EMC and the BED.

2.2.6.1.1 EACT Staffing and Responsibilities. The RL Manager shall be the EACT Director. In the absence of the RL Manager, the RL Deputy Manager shall act as EACT Director. He or she is responsible for directing the operations of the RL-ECC and ensuring 
implementation of the responsibilities of RL as lead federal agency. In consultation with the EACT staff, the EACT Director approves emergency reclassification and termination, offsite PARs, and notifications.

The EACT is primarily staffed by RL personnel with support from contractor personnel. The RL shall train to a lovel of three deep for each of the staff positions.

The EACT staff positions and specific responsibilities shall be contained in DOE-0223. Once operational, general functions of the EACT include:

- Overviewing onsite response and mitigation actions, and providing assistance to the event contractor as needed

- Providing offsite notifications and PARs to state, local, and federal agencies, and continuous updates to the state/counties about conditione

NOTE: Prior to the RL-ECC being operational, the ONC shall make these notifications and provide predetermined PARs.

- Providing direction and control of the event, as appropriate (security declaration takes precedence in combined security/safety events) in an RL-declared security ovent

- Reclassifying or terminating the emergency

- Directing the activities of the JIC in providing timely and accurate release of information to the public and media, including approval of all RL news releases

- Providing an RL spokesperson to the JIC

- Requesting additional federal assets, as needed

- Providing liaisons to offsite emergency centers and responding federal assets

- Providing a representative to DOE-HO as requested

- Designating a recovery organization.

2.2.6.2 Unified Dose Assessment Center. The UDAC is contractor operated for RL and is responsible for providing evaluations, communications and PARs in the areas of industrial hygiene, radiological assessment, biology/chemistry, environmental monitoring, and meteorology.

The UDAC Manager reports to UDAC/DOE Representative, who reports to the Safety Director in EACT. Specific UDAC responsibilities include:

- Acquiring necessary data and measurements to evaluate personnel radiation doses and chemical exposures resulting from the event 
- Assessing the potential for onsite and offsite consequences of a release of radioactive or nonradioactive materials based on meteorological conditions, source term, location and dispersal of the hazards material

- Assisting the Event Contractor or other Hanford Site contractors in onsite hazard assessment or development of onsite PARs, as requested

- Developing offaite PARs in coordination with representatives from the states of Washington and Oregon.

The UDAC is staffed by contractor personnel with knowledge in the technical areas of meteorology, health physics, biology, toxicology, and industrial hygiene. Additionally, representatives from RL and the states of Washington and Oregon participate in the UDAC. Procedures for the staffing and operation of the UDAC are contained in DOE-0223.

2.2.6.3 Field Team Coordination Center. The FTCC, operated by contractor personnel for RL, is responsible for the coordination and direction of all emergency environmental monitoring teams that are not assigned to the event facility. This may include coordination and direction of state field teams if requested by the states. The FTCC Director reports to the UDAC Manager.

The FTCC procedures are contained in DOE-0223.

2.2.6.4 Joint Information Center. The JIC provides a single location where RL and its contractors can coordinate the release of information with other federal agency, state, and local jurisdictions. The JIC operates under the direction of the EACT Public Affairs Director and is managed and staffed by RL and contractor personnel. Provisions shall be made at the JIC for representatives from the states of Oregon and Washington, plume emergency planning zone counties, and other federal agencies who may be involved in the emergency response.

The functions performed at the JIC include:

- Preparing and coordinating information released to the public and media

- Answering questions of the public and media

- Rumor control.

The manner in which these responsibilities are met is described further in Section 9.0, and in DOE 0223. 
DOE/RL-94-02, Rev. 0

This page intentionally left blank. 
DOE/RL-94-02, ROV. 0

\subsection{OFFBITE RESPONSE INTERFACES}

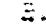

...

\subsection{OVERVIEW}

Interfaces and coordination with offaite agencies are important in all phases of the emergency management program - planning, preparedness, response, and recovery. The RL shall interface with local, state, tribal, federal and private organizations, such as:

- Agencies that have a responsibility to protect the public and environment within the EPZs of the Hanford Site

- Agencies with which RL coordinates response as the Regional Coordinating Office of the RAP for Region 8

- Agencies with which RL has entered into special agreements for assistance.

Where appropriate, RL shall develop and maintain agreements to formalize areas of underatanding, cooperation, and support with offsite agencies.

\subsubsection{Planning and Preparedness}

The modes of interface for planning and preparedness activities, as is determined beneficial by the parties, may include:

- Coordination of emergency plans and procedures

- Periodic meetings to share information and coordinate activities

- Training opportunities related to offsite responsibilities

- Development of agreements for support to and from offsite agencies

- Participation in annual field exercises

- Development of public information programs.

\subsubsection{Response and Recovery}

In the event of an emergency on or affecting the Hanford Site, RL shall interface with offsite agencies to ensure coordination and support of response and recovery activities. These interfaces include:

- Notification and periodic updates to local jurisdictions within the plume EPZ, states that contain portions of an ingestion EPZ, and other agencies that may be requested to provide assistance (see Section 6.0)

- Communication and coordination with DOE-HQ

- RL representation in appropriate offsite emergency centers 
- Offeite representation in RL emergency centers, to include EACT, UDAC/FTCC and the JIC

- PARs to offsite agencies

- Event scene interface with offsite responders.

Communications with state and local EOCs are depicted on Figure 3-1.

\subsection{FEDERAL AGENCIES}

\subsubsection{Department of Energy-Headquarters}

The DOE-HO Program Secretarial Officers (PSO) are responsible to ensure the preparation and maintenance of plans, procedures, and capabilities for responding to emergencies affecting their areas of cognizance. The RL shall submit the Hanford Emergency Response Plan to the cognizant PSO for review and final approval, with the DOE-HQ Director of Emergency Operations providing concurrence. to:

In the event of an emergency, a DOE-HO Emergency Management Team is convened

- Provide overall guidance and direction for the DOE-HO emergency response

- Monitor field response activities

- Provide support to the fisld in conducting their response activities

- Coordinate deployment of DOE emergency response assets

- Notify and coordinate with other DOE elements, the White House, Congress, other federal agencies, and the national news media, as appropriate.

The RL shall notify and provide information to the DOE-HO-EOC. Written reports shall be provided to the DOE-HQ-EOC as soon as practical, but within 24 hours of emergency classification. A DOE-HO Site Representative will respond to the RL-ECC to provide liaison with the DOE-HO-EOC. Upon request of DOE-HO, RL shall dispatch a liaison to support activation of the DOE-HQ-EOC.

\subsubsection{Federal Bureau of Investigation}

The role of the FBl is to serve as the primary U.S. Law Enforcement Agency responsible for investigating alleged or suspected violations of the Atomic Energy Act of 1954, as amended, and other federal statutes. All emergencies of national consequence occurring at the Hanford Site and within the jurisdiction of the U.S. Department of Justice will be 


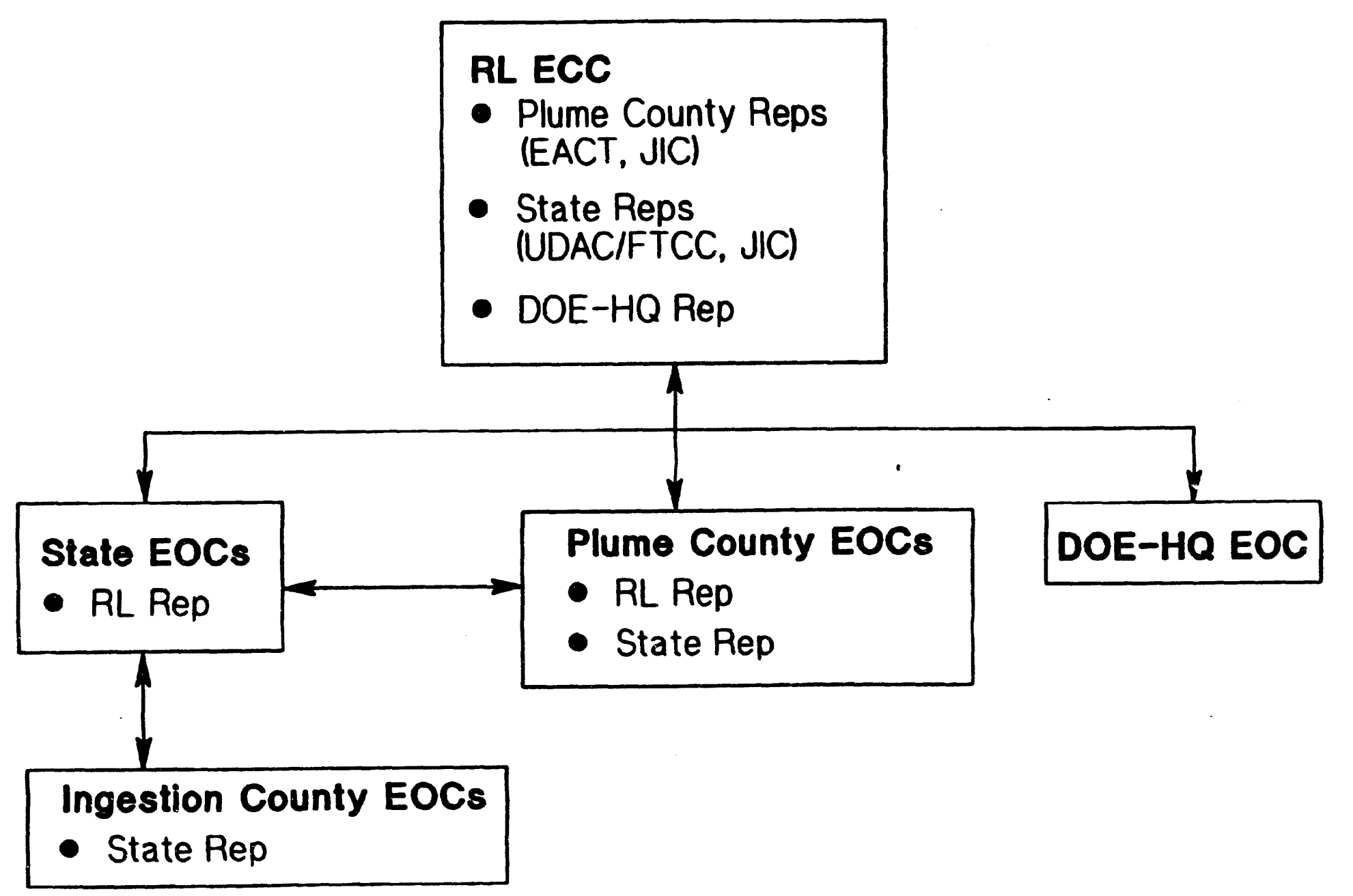


communicated to the FBI. Command of FBI response activities, including plant security forces deployed at the event scene, will be the responsibility of the FBI Special-Agent-in-Charge when a declared security event has occurred. The RL will retain command and control of a declared security event until the FBI assumes this responsibility.

The RL Safeguards and Security (SAS) Branch shall interface and maintain a memorandum of understanding with the FBI.

\subsubsection{U.S. Coast Guard}

The U.S. Coast Guard (USCG) (through the Thirteenth District Commander in Seattle, Washington and the Captain of the Port in Portland, Oregon) may regulate activities on navigable waters within the Hanford Site when necessary to prevent harm to persons, property, and the environment in or on those waters.

Through a memorandum of understanding with USCG, RL, Supply System, and Benton and Franklin Counties, the USCG will close the appropriate portion of the Columbia River and make a broadcast to mariners when notified of a Site Area or General Emergency.

In the event of an emergency the ONC or the RL-ECC will make notifications and provide information to the USCG in Portland, Oregon.

\subsubsection{U.S. Environmental Protection Agency}

Under the provisions of the Federal Radiological Emergency Response Plan, the U.S. Environmental Protection Agency (EPA) shall assume the lead federal agency responsibility for coordinating the intermediate and long-term offsite radiation monitoring activities.

In the event of an emergency, the RL-ECC shall notify and provide information to the EPA Region 10 in Seattle, Washington.

\subsubsection{Foderal Aviation Administration}

The Federal Aviation Administration (FAA) may make flight restrictions for aircraft under their jurisdiction over the Hanford Site.

The RL-ECC or ONC will notify and provide information to the FAA Seattle Center. At a Site Area or General Emergency the RL-ECC or ONC may request the FAA to impose flight restrictions over the Hanford Site. 


\subsubsection{Foderal Emergoncy Management Agency}

The Federal Emergency Management Agency (FEMA) is responsible for coordinating federal assistance (other than monitoring resources) to the states if requested. Under the provisions of the Federal Radiological Emergency Response Plan FEMA, coordinates the offaite (nontechnical) response.

At the time of a declaration of an emergency, the RL-ECC notifies and provides information to the FEMA Region 10 office in Bothell, Washington.

\subsection{STATE GOVERNMENT}

States, along with local governments, share the responsibility for the protection of the public and the environment. The responsibilities and concept of operations for state agencies are described in the emergency response plans of each state.

The RL shall work with the states of Washington and Oregon to assist in development of their program and response plans for an emergency at the Hanford Site. Periodic meetings will be conducted with the states to coordinate plans and share information. General descriptions of emergency responsibilities, and areas of cooperation and understanding between RL and the states are delineated in memorande of understanding (see Appendix B).

\subsubsection{Washington State}

The Governor of the State of Washington is responsible for command and control of state resources in order to maintain and preserve life, property, and the environment in the State of Washington. The lead agency for emergency planning and response activities is the Emergency Management Division of the Department of Community. Trade and Economic Development. Other State agencies that participate in the planning process and have emergency response roles include:

- Department of Health

- Department of Agriculture

- State Patrol

- Department of Ecology

- Military Department

- Department of Transportation.

The Washington State Hanford Emergency Response Plan is maintained by the Emergency Management Division and describes the concept of operations, and roles and responsibilities of state agencies. Emergency procedures are maintained by each State agency.

Responsibilities of the State of Washington include:

- Providing a 24-hour single point of contact for the receipt of emergency notifications from RL 
- Disseminating information to potentially affected counties within the plume and ingestion EPZ

- Coordinating ingestion protective action decisions and public information with the counties, Oregon State, and RL

- Providing assistance to counties as requested

- Evaluating offsite emergency PARs made to plume EPZ counties

- Making protective action decisions to protect public health from ingestion-related impacts, such as contamination of the food chain

- Performing field environmental radiological monitoring and dose assessments

- Providing quidance on emergency worker exposure and authorizing emergency workers to exceed protective action guides

- Implementing food, milk, and animal-feed control measures

- Requesting federal assistance, as required.

\subsubsection{Oregon State}

The Governor of the State of Oregon is responsible for directing and controlling all State activities to protect the lives and property of the State of Oregon citizens. The lead agency for the Hanford Site Emergency Planning is the Oregon DOE. Other State agencies that participate in the planning process and have emergency response roles include:

- State Public Information Officer

- Health Division

- Emergency Management Division

- Department of Agriculture

- Oregon State University Radiation Center

- Military Department

- State Police

- State Highway Division.

The Oregon State Hanford Emergency Response Program for DOE facilities is maintained by the Oregon DOE and describes the concept of operations and roles and responsibilities of State agencies. Emergency procedures are maintained by each State agency.

Responsibilities of the State of Oregon include:

- Providing a 24-hour single point of contact for the receipt of emergency notifications from RL

- Making protective action decisions for the State of Oregon 
- Coordinating protective action decisions and public information with counties, the State of Washington, and RL

- Coordinating state and local emergency response within the State of Oregon

- Performing field environmental radiological monitoring and dose assessments

- Providing guidance on emergency worker exposure and authorizing emergency workers to exceed protective action guides

- Providing assistance to the State of Oregon counties within the ingestion EPZ

- Implementing food, milk, and animal-feed control measures

- Requesting federal assistance, as required.

\subsection{LOCAL OROANIZATIONS}

Cities and counties are responsible for protecting the lives and property of their residents. The responsibilities and concept of operations for local governments are described in the emergency response plans of each jurisdiction.

The RL shall work with local emergency response organizations through the county and state emergency management organizations. Generally, RL shall interface directly with local emergency response and planning organizations providing service to those areas within a plume EPZ of a Hanford Site facility. Interface with those jurisdictions within the ingestion EPZ shall generally be accomplished through the state emergency management organization. To accomplish the necessary close coordination with local agencies, periodic meetings shall be conducted to share information and discuss concerns.

\subsubsection{Plume Emergency Planning Zone Countles}

Benton, Franklin, and Grant Counties are within interim plume EPZs of a Hanford Site facility. The Boards of County Commissioners are responsible for making emergency protective action decisions and implementing emergency response actions, as necessary, to protect their residents outside the Henford Site boundary. The lead agency for emergency planning and coordination of emergency response is the county emergency management agency. County emergency response plans and procedures are developed by the emergency management agencies, working with county, city, and volunteer emergency response agencies, such as:

- Law Enforcement

- Fire and Emergency Medical

- Public Works/Road Departments

- Hospitals

- American Red Cross. 
The emergency responsibilities of the plume EPZ counties in : de:

- Making and/or implementing protective action decisions to protect citizens that live within the plume EPZ

- Implementing protective action decisions, made by the State of Washington, for ingestion related impacts to residents within the ingestion EPZ

- Disseminating alert and warnings to the public and providing emergency public information

- Coordinating response actions and public information with neighboring counties, the State of Washington, and RL.

The RL maintains agreements with Benton, Franklin, and Grant Counties that outline the areas of responsibility and cooperation (see Appendix B).

3.4.1.1 Law Enforcement. The RL SAS interfaces with local law enforcement agencies for support to the Hanford Site during emergencies. Included in this interface is maintenance of the Law Enforcement Assistance Plan (see Appendix A) which describes the containment support provided by Benton, Franklin, Grant, and Adams County Sheriff's Offices, and Richland, Pasco, and Kennewick Police Departments.

Via a contractual agreement, the Benton County Sheriff's Office provides law enforcement on the Hanford Site (i.e., traffic enforcement and criminal investigation), and assists in access control; and, as such, coordinates activities with RL SAS and the Hanford Patrol.

The RL SAS maintains memorandums of understanding with the law enforcement agencies of Kennewick, Richland, West Richland, Benton County, Franklin County, and the State of Washington.

3.4.1.2 Fire and Emergency Medical. The Hanford Fire Department is signatory to the Tri-Cities Mutual Aid Agreement for fire agencies. The agreement, signed by 11 local fire agencies, provides mutual aid for fire or medical emergencies.

The Hanford Fire Department meets regularly with local fire agencies. The Hanford Fire Department and HEHF Representatives meet routinely with emergency medical services agencies to coordinate and share information.

3.4.1.3 Hospitals. The RL maintains agreements with the following local hospitals which provide for the care of radiologically contaminated Hanford Site personnel:

- Our Lady of Lourdes Health Care Center

- Kennewick General Hospital

- Kadlec Medical Center. 
The RL shall provide for training and exercise support related to the services provided to the Hanford Site. The HEHF shall provide expertise on radiological decontamination or chemical exposure and treatment, as requested.

\subsubsection{Ingestion Emergency Planning Zone Counties}

Counties within the ingestion EPZ of the Hanford Site are responsible to implement measures to protect their residents from potential ingestion related impacts. In the State of Washington, the counties of Walla Walla, Franklin, Benton, Adams, Grant, and Yakima are within the interim 50 mile ingestion EPZ. In the State of Oregon, the counties of Morrow and Umatilla are included. Ingestion EPZ counties have emergency response plans that describe their responsibilities in the event of an emergency at the Hanford Site.

The RL shall coordinate emergency planning and preparedness for ingestion counties through the Washington State Emergency Management Division and the Oregon Department of Energy.

Ingestion county responsibilities include:

- Coordinating with the State and implementing decisions regarding protective measures for its residents within the ingestion EPZ

- Consulting with the State EOC on the identification of access control points, food control areas, food control stations, and strategies for relocation, restoration, and recovery in contaminated areas.

\subsection{TRIBAL ORGANIZATIONS}

Upon finalization of the ingestion EPZ, RL shall interface with the impacted tribal organizations to coordinate planning for ingestion-related response actions of the tribe(s).

\subsection{PRIVATE ORGANIZATIONS}

The Hanford Site emergency management program shall address private facilities on or near the Hanford Site. These facilities may be impacted by an emergency at the Hanford Site, or may impact Hanford Site facilities if they experience an emergency.

The RL shall coordinate emergency planning and preparedness activities with onsite private facilities (namely WNP-2 and U.S. Ecology). In the event of an emergency at a Hanford Site facility, onsite private facilities will receive notifications and information from RL.

Where emergencies at offsite facilities operated by private organizations may impact the Hanford Site, such as Siemens Nuclear Power Corporation or WNP-2, RL shall ensure that the emergency management program addresses actions that must be taken to protect Hanford Site workers and facilities. 
Areas of cooperation with private organizations shall be documented in memorandums of understanding (see Appendix B).

\subsection{MEMORANDA OF UNDERSTANDINO}

The RL shall enter into agreements with offsite organizations to document areas of cooperation and assistance (see Table 3-1).

The RL Quality, Safety, and Health Program Division (2SH) is responsible for executing and maintaining Memoranda of Understanding (MOU) related to emergency preparedness. RL SAS and the Hanford Fire Department shall execute and maintain MOUs with their areas of responsibility. MOUs shall be reviewed annually and revised as needed. 
DOE/RL-94-02, Rev. 0
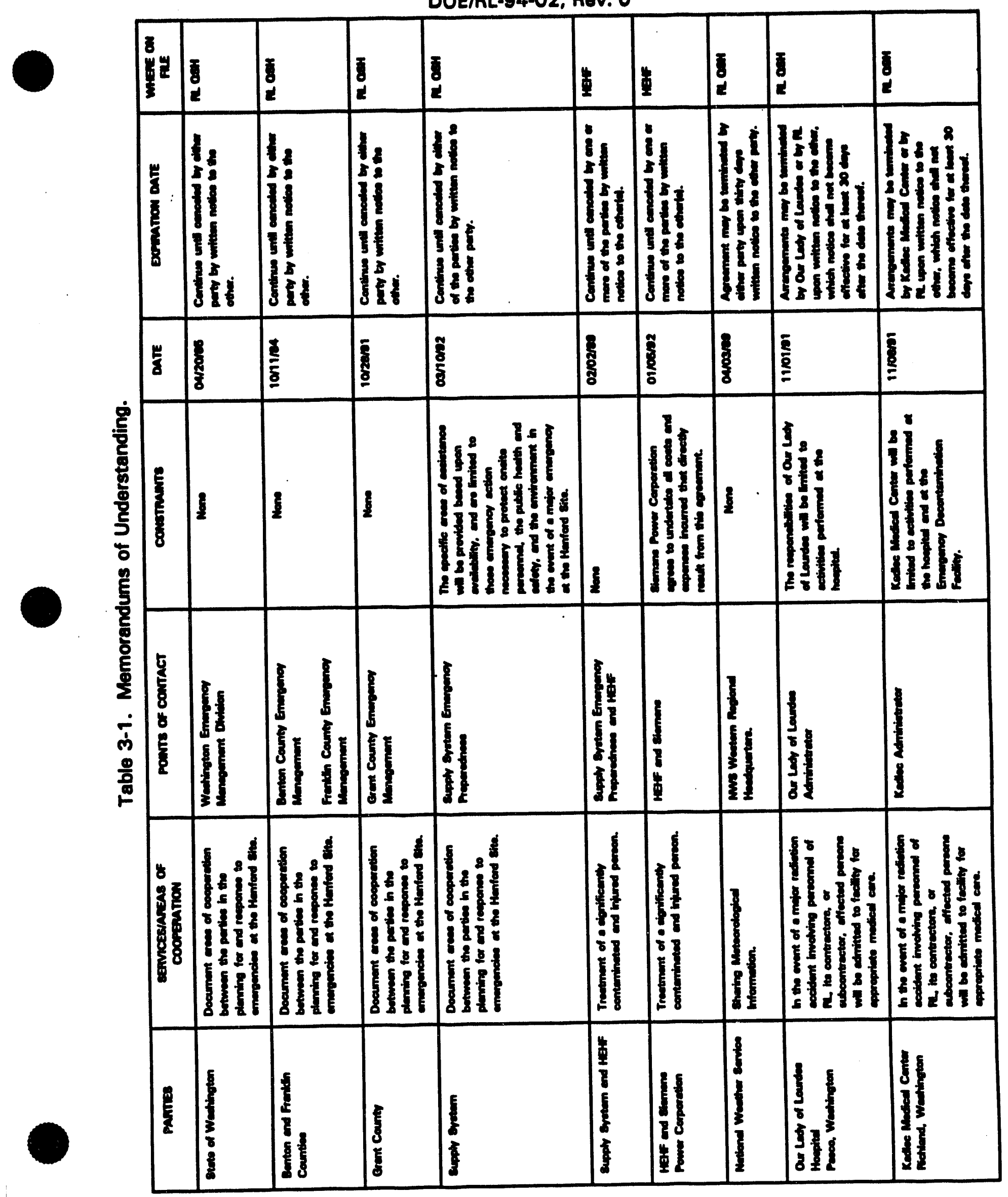
Table 3-1. Memorandums of Understanding.

\begin{tabular}{|c|c|c|c|c|c|c|}
\hline Pantres & 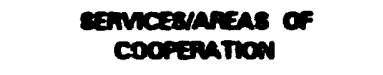 & PowTs of contact & conomanrs & oare & Domanom oare & $\begin{array}{l}\text { whes on } \\
\text { fur }\end{array}$ \\
\hline 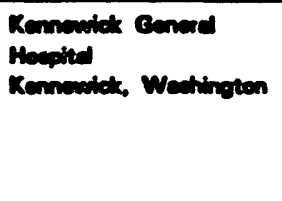 & 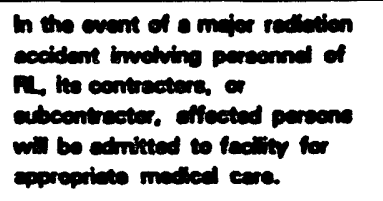 & 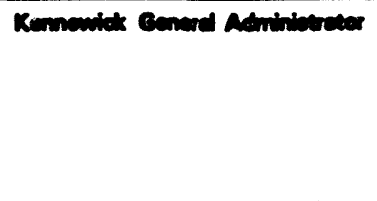 & 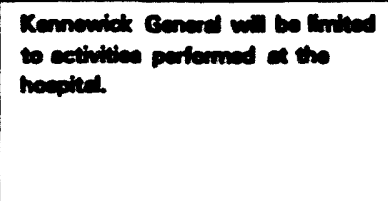 & 10raser & 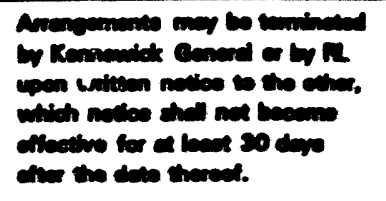 & nom \\
\hline 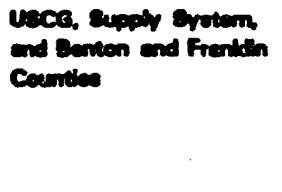 & 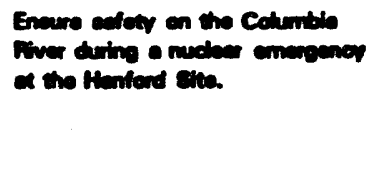 & 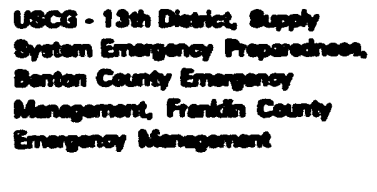 & 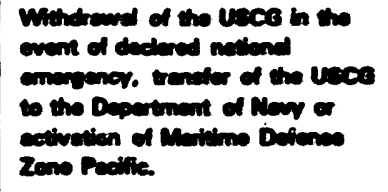 & ornass & 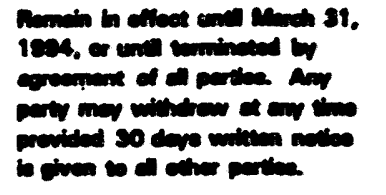 & now \\
\hline suces of Oresen & 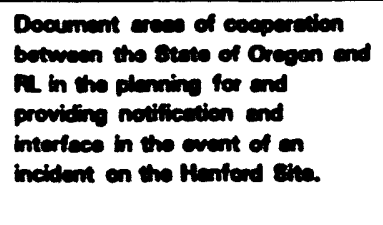 & Oresen Depertinere ef Envigy & Nono & $12002 \%$ & 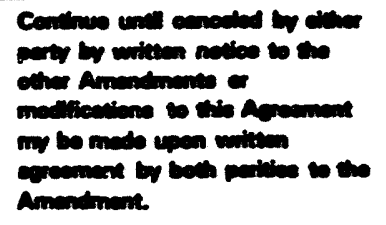 & now \\
\hline 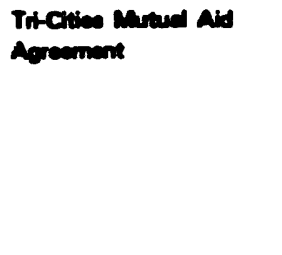 & 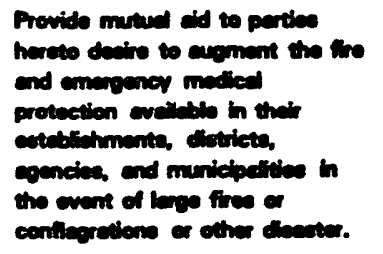 & Fetiend Firo Depertineme & 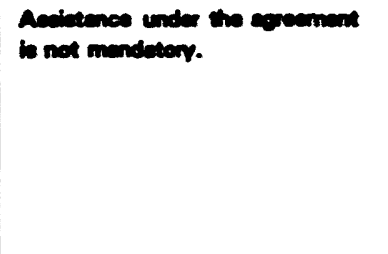 & ourasus & 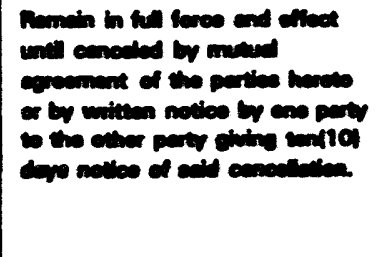 & Fo \\
\hline 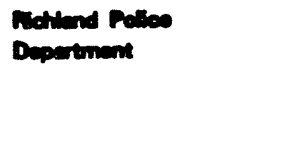 & 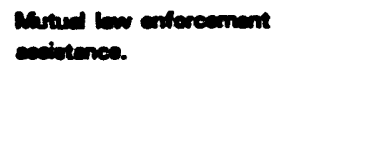 & 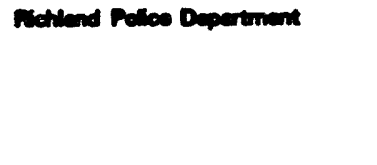 & 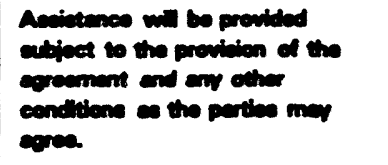 & orneme & 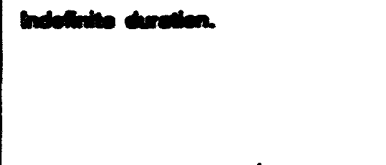 & $n \operatorname{sen}$ \\
\hline $\begin{array}{l}\text { Weat richiond Potioe } \\
\text { Depertunat }\end{array}$ & 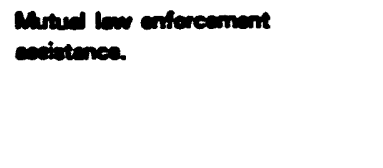 & 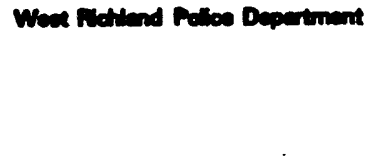 & 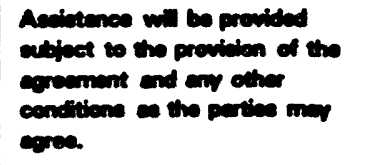 & arrans & 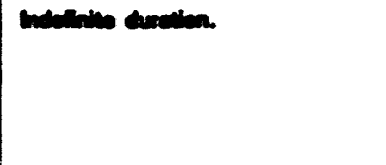 & neas \\
\hline $\begin{array}{l}\text { Rennevick Policos } \\
\text { Depertinant }\end{array}$ & 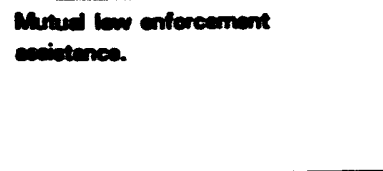 & 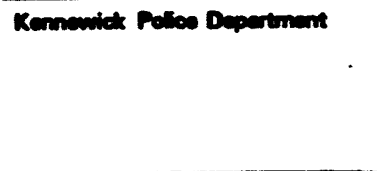 & 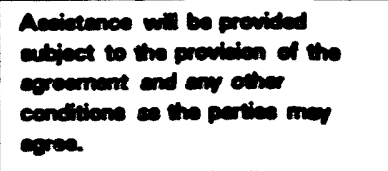 & corrans & 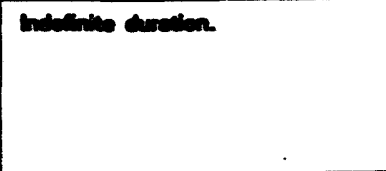 & $n e n$ \\
\hline Domen Coumy Ehaill & 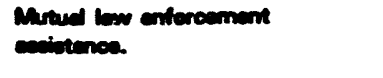 & Ement Coumer strain & 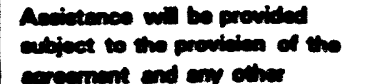 & omman & 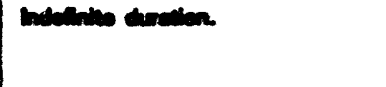 & $n \operatorname{ces}$ \\
\hline
\end{tabular}


DOE/RL-94-02, Rev. 0
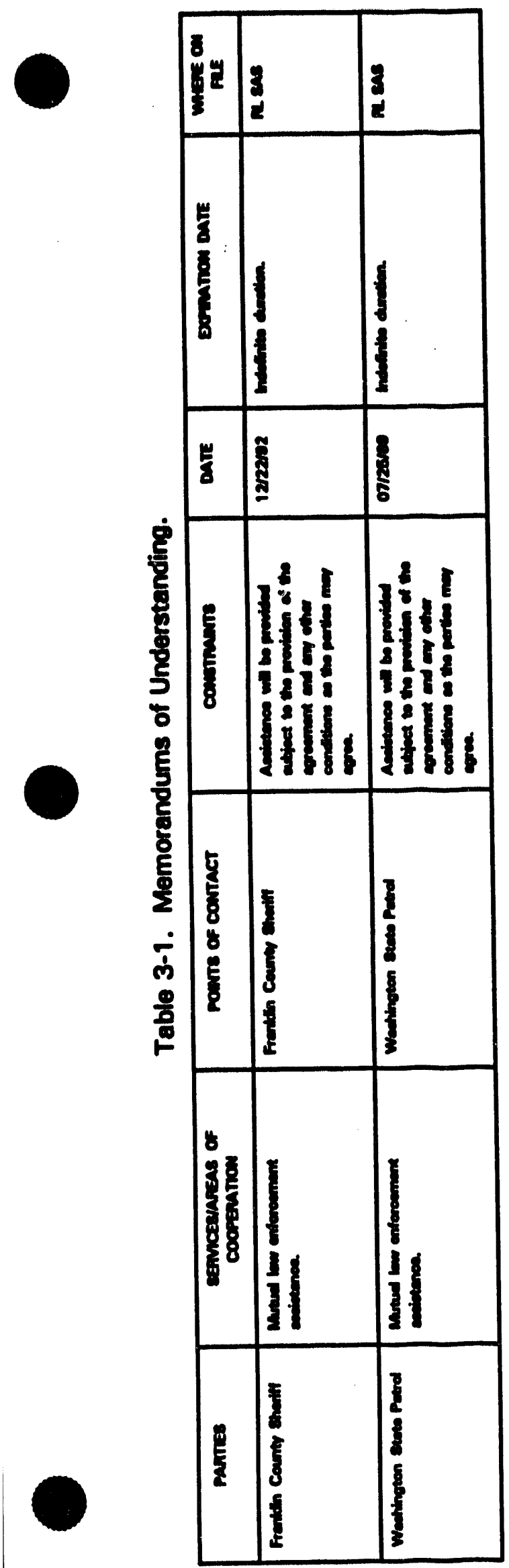
DOE/RL-94-02, Rov. 0

This page intentionally left blank. 


\subsection{A88E88MENT AND CLAS8IFICATION}

This section describes hazards assessment, the methods that shall be used to detect and recognize emergencies, and the initial and continuous assessments that are necessary to protect workers, the public, and the environment.

\subsection{HAZARDS A88E8SMENT}

Hazards assessments provide the technical basis for the emergency management program. The extent of planning and preparedness directly corresponds to the type and scope of hazards present and the potential consequences of events. Hazards assessments shall be prepared and maintained for each hazardous facility (i.e., facilities that could generate an Alert level or higher emergency).

The Hanford Site hazardous facilities assessments shall identify and characterize the hazards relevant to potential operational emergencies at a facility. This shall include determination of:

- The broad range of initiating events

- Accident mechanisms

- Equipment or system failures

- Event indications

- Contributing events

- Source terms

- Material release characteristics

- Topography

- Environmental transport and diffusion

- Exposure considerations.

The hazards assessment shall characterize the potential onsite and offsite consequences of each postulated accident and determine the size of the EPZ.

A spectrum of potential accidents ranging from minor to beyond-the-design basis shall be postulated and realistically analyzed. While not every conceivable situation will be analyzed, the hazards assessments will provide the framework for response to virtually any emergency.

The methodology, assumptions, models, and evaluation techniques used in the hazards assessment shall be documented. They shall be reviewed and updated, as necessary. whenever the facility configuration changes, source terms change, or the operations of the facility are modified. These documents shall be maintained as a supporting document in accordance with contractor document control requirements. 


\subsection{OPERATIONAL EMEROENCY CLASSIFICATION}

An operational emergency is defined as one of the three categories of emergencies described in DOE Order 5500.28 (DOE 1991a). Operational Emergencies are significant accidents, incidents, events, or natural phenomena which seriously degrade the safety or security of DOE facilitios. Operational Emergencies apply to DOE reactors and other DOE facilities (nuclear and nonnuclear) involved with hazardous materials; DOE-controlled nuclear weapons, components, or test devices; DOE SAS events; and transportation accidents involving hazardous material.

Pre-emergency conditions which warrant increased SAS measures shall be reported in accordance with DOE Order 5000.3B.

There are three emergency event classes; Alert, Site Area Emergency, and General Emergency, which are described in the following section.

\subsubsection{Emorgency Classes}

4.2.1.1 Alert. An emergency class within the Operational Emergency category of emergency. Within the Operational Emergency category, an Alert represents events in progress or having occurred which involve an actual or potential substantial reduction for the level of facility safety and protection. Any environmental release of hazardous materials are expected to be limited to small fractions (10 percent) of the appropriate Protective Action Guideline (PAG) or Emergency Response Planning Guideline (ERPG) (ERPG-1) at the facility boundary. (See Table 4-1).

At an Alert, the Hanford Site emergency response organization shall:

- Provide continuous assessment of pertinent information for contractor and DOE decision-makers, offsite authorities, the public, and other appropriate entities

- Conduct appropriate assessments, investigations, or preliminary or confirmatory sampling and monitoring

- Mitigate the severity of the occurrence or its consequences

- Establish communication, consultation and liaison with offsite authorities

- Prepare for other response actions should the situation become more serious (requiring emergency response organizations to mobilize or activate resources)

- Activate all onsite affected emergency centers.

4.2.1.2 Site Area Emergency. An emergency class within the Operational Emergency category. Within the Operational Emergency category, a Site Area Emergency represents ovents which are in progress or have occurred involving actual or likely major failure(s) of 
Table 4-1. Summary of Emergency Classes.

\begin{tabular}{|c|c|c|c|}
\hline $\begin{array}{c}\text { Emorgency } \\
\text { Class }\end{array}$ & Facility & $\begin{array}{c}\text { Safeguards } 8 \\
\text { Security }\end{array}$ & Transportation \\
\hline ALERT & $\begin{array}{l}\text { Subatantial } \\
\text { actual/potential } \\
\text { degradation of level } \\
\text { of safety. Releases } \\
\text { not expected to } \\
\text { exceed PAG/ERPG } \\
\text { levels at facility } \\
\text { boundary. }\end{array}$ & $\begin{array}{l}\text { Substantial } \\
\text { actual/potential } \\
\text { degradation of level } \\
\text { of protection or the } \\
\text { loss or potential loss } \\
\text { of special nuclear } \\
\text { material (SNM). } \\
\text { Releases not } \\
\text { expected to exceed } \\
\text { PAG/ERPG levels at } \\
\text { facility boundary. }\end{array}$ & $\begin{array}{l}\text { Substantial } \\
\text { actual/potential } \\
\text { degradation of the } \\
\text { safety of the } \\
\text { shipment. Exposures } \\
\text { in excess of } \\
\text { PAG/ERPG levels only } \\
\text { expected for personnel } \\
\text { engaged in cleanup. } \\
\text { recovery and } \\
\text { investigation (on or } \\
\text { offsite accident). }\end{array}$ \\
\hline $\begin{array}{l}\text { SITE AREA } \\
\text { EMERGENCY }\end{array}$ & $\begin{array}{l}\text { Actual/potential } \\
\text { major failures of } \\
\text { functions needed for } \\
\text { protection of workers } \\
\text { and public. Releases } \\
\text { could exceed } \\
\text { PAG/ERPG levels } \\
\text { onsite, but not } \\
\text { offsite. }\end{array}$ & $\begin{array}{l}\text { Actual malevolent } \\
\text { acts resulting in } \\
\text { major failures of } \\
\text { protective systems. } \\
\text { Releases could } \\
\text { exceed PAG/ERPG } \\
\text { beyond facility } \\
\text { boundary but not } \\
\text { offsite. }\end{array}$ & $\begin{array}{l}\text { Actual/potential major } \\
\text { reduction in safety of } \\
\text { a shipment. Onsite, } \\
\text { release may exceed } \\
\text { PAG/ERPG lovels } \\
\text { beyond "exclusion } \\
\text { zone"1 onsite but not } \\
\text { at nearest Site } \\
\text { boundary. Offsite, } \\
\text { release not to exceed } \\
\text { PAG/ERPG levels } \\
\text { outside "exclusion } \\
\text { zone."1 }\end{array}$ \\
\hline $\begin{array}{l}\text { GENERAL } \\
\text { EMERGENCY }\end{array}$ & $\begin{array}{l}\text { Actual/imminent } \\
\text { catastrophic } \\
\text { reduction of safety } \\
\text { systems with } \\
\text { potential or actual } \\
\text { loss of hazardous } \\
\text { material. Releases } \\
\text { reasonably expected } \\
\text { to exceed PAG or } \\
\text { ERPG levels offsite. }\end{array}$ & $\begin{array}{l}\text { Malevolent action } \\
\text { resulting in } \\
\text { catastrophic } \\
\text { degradation of } \\
\text { protection systems } \\
\text { that could lead to } \\
\text { substantial offsite } \\
\text { impacts. }\end{array}$ & $\begin{array}{l}\text { Actual/imminent } \\
\text { catastrophic reduction } \\
\text { in safety of a } \\
\text { shipment. Onsite, } \\
\text { releases expected to } \\
\text { exceed PAG/ERPG } \\
\text { levels offsite. Offsite, } \\
\text { releases likely to } \\
\text { exceed PAG/ERPG } \\
\text { levels outside of } \\
\text { "exclusion 2one."1 }\end{array}$ \\
\hline
\end{tabular}

'Exclusion zone = the immediate vicinity of the accident. 
facility safety or safeguards systems needed for the protection of onsite personnel, the public health and safety, the environment, or national security. Any environmental releases of hazardous materials are not expected to exceed the appropriate PAG $(1 \mathrm{rem}$ committed effective dose equivalent [CEDE]) or ERPG (ERPG-2) exposure levels beyond the facility boundary, but less than these values at the Hanford Site Boundary.

At a Site Area Emergency, the Hanford Site emergency response organization shall:

- Activate the response centers and other emergency assets to provide continuous assessment of information

- Provide continuous assessment of pertinent information for contractor and DOE decision-makers, offsite authorities, and other appropriate entities

- Establish communications, consultation, and liaison with onsite organizations and personnel

- Establish communications, consultation, and liaison with offsite authorities

- Provide information to the onsite personnel and organizations, and the public through onsite and offsite authorities and the media

- Conduct or assist in any evacuations and sheltering

- Conduct appropriate assessments, investigations, or sampling and monitoring

- Mitigate the severity of the actual or potential consequences

- Mobilize appropriate emergency response groups or security forces for immediate dispatch should the situation become more serious.

4.2.1.3 General Emergency. An emergency class within the Operational Emergency sategory. Within the Operational Emergency category, a General Emergency represents events which are in progress or have occurred that involve actual or imminent catastrophic failure of facility safety systems with potential for loss of confinement integrity, catastrophic degradation of facility protection systems, or catastrophic failure in safety or protection systems threatening the integrity of a weapon or test device which could lead to substantial offsite impacts. Any environmental release of hazardous materials can reasonably be expected to exceed the appropriate PAG (1 rem) or ERPG (ERPG-2) exposure levels at or beyond the Hanford Site Boundary.

At a General Emergency, the Hanford Site emergency response organization shall:

- Activate the response centers and other emergency assets to provide continuous assessment of information

- Establish communications, consultation, and liaison with offsite authorities and recommend predetermined protective actions for the public 
- Provide information to onsite personnel, the public, offsite authorities, and the media

- Conduct or assist evacuations and sheltering

- Conduct appropriate assessments, investigations, or sampling and monitoring

- Mitigate the severity of the actual or potential consequences

- Mobilize and dispatch appropriate emergency response groups or security forces.

\subsection{EMERGENCY ACTION LEVELS}

The EALs are specific, predetermined, observable criteria used to detect, recognize, and determine the classification of Operational Emergencies. The EALs are typically identified as either event-based, or symptom-based. The distinction arises from the available methods of detecting and recognizing the event initiating conditions. The development of symptom-based EALs is the preferred approach, recognizing that there will usually be some initiating conditions that require an event-based approach.

Facility-specific emergency action levels shall be developed for all Hanford Site DOE facilities in accordance with DOE Order 5500.2B and the Emergency Management Guide (DOE 1991 b) regarding Hazards Assessment and Event Classification. The EALs shall be reviewed annually and coordinated with appropriate offsite federal, state, tribal and local organizations.

The definitions in Section 4.1, in conjunction with Table 4-2, depict the criteria used at the Hanford Site to classify emergency events. Contractor facility managers or BEDs are responsible for making initial classification of emergency events in accordance with RL and Contractor Procedures.

\subsubsection{Symptom Based Emergency Action Levels}

Symptom-based EALs are dependent on one or more observable conditions or parameter values (i.e., symptoms) that are measurable over some continuous spectrum. The EALs should be the same indicators as those used to monitor routine facility operation. The level of severity indicated by these symptoms is directly related to the failure of or challenge to the facility's hazardous materials confinement barriers, other symptoms or events that occur simultaneously, and the ability of personnel to gain control and bring the indicator(s) back to safe levels. The resulting facility-specific EALs shall consist of specific quantified values (e.g., alarms and control instrument readings) which require no additional interpretation by the user. By comparing the observed value to the EALs in event classification procedures, the correct emergency class can be readily determined. 
DOE/RL-94-02, Rev. 0

Table 4-2. Hanford Site Emergency Event Classification Criteria.

\begin{tabular}{|c|c|c|}
\hline ALERT & SITE AREA EMERGENCY & GENERAL EMERGENCY \\
\hline $\begin{aligned}>= & \text { ERPG'-1 \& }<\text { ERPG- (2) } \\
& \text { Facility Boundary } 2 .\end{aligned}$ & 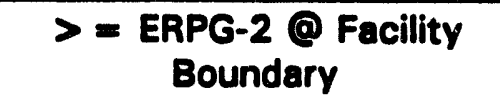 & $\begin{array}{c}>=\begin{array}{c}\text { ERPG-2 @ Hanford } \\
\text { Site Boundary }\end{array}\end{array}$ \\
\hline $\begin{array}{l}>=100 \text { mrem CEDE, or } \\
0.5 \text { rem to the thyroid, } \\
\text { or } 5 \text { rem to the skin } \\
\text { ه Facility Boundary. }\end{array}$ & $\begin{array}{c}>=1 \text { rem CEDE, or } 5 \\
\text { rem to the thyroid, or } 50 \\
\text { rem to the skin @ Facility } \\
\text { Boundary. }\end{array}$ & $\begin{array}{l}>=1 \text { rem CEDE, or } 5 \text { rem } \\
\text { to the thyroid, or } 50 \text { rem to } \\
\text { the skin @ Site Boundary. }\end{array}$ \\
\hline 1 ERPG Values & \multicolumn{2}{|c|}{$\begin{array}{l}\text { Appropriate.ERPG or equivalent as stated in the Hazards } \\
\text { Assessment Guidance Document. Solubility class "D" } \\
\text { uranium compounds are limited by chemical toxicity. }\end{array}$} \\
\hline 2 Facility Boundary & \multicolumn{2}{|c|}{$\begin{array}{l}\text { Facility Boundary is defined as the property-protected } \\
\text { area perimeter fence when present or a distance of } \\
200 \text { meters from the release location unless otherwise } \\
\text { specified in the hazards assessment documentation. }\end{array}$} \\
\hline , CEDE & \multicolumn{2}{|c|}{$\begin{array}{l}\text { The committed dose includes the summation of the } \\
\text { doses delivared from plume submersion, ground shine, } \\
\text { and inhalatiori from accidental releases. }\end{array}$} \\
\hline
\end{tabular}

\subsubsection{Event Based Emergency Action Levels}

Event-based EALs address the occurrence of discrete events with potential safety significance. The level of severity is determined by the degree to which hazardous material confinement barriers are either failed or challenged as a result of the event, and the ability of personnel to gain control of the situation. Event classification requires the interpretation of one or more qualitative conditions or discrete observable indicators to determine if the existing situation matches the descriptions contained in the event classification procedure.

\subsubsection{Emergency Action Level Development}

The methodology for development of Hanford Site EALs is described in the following paragraph. There are several steps in the assessment process used to develop EALs.

Step 1: Define and describe the facility and its operations. This is accomplished through review of SARs prepared for the subject facility.

Step 2: Identify and screen the hazards (both radiological and nonradiological). Threshold values of radiological and nonradiological materials are reviewed to determine those materials which exceed established criteria. These lists of materials are obtained from documents such as SARs, Safety 
Assessments, Facility Hazards Classification documentation, and Superfund Amendments and Reauthorization Act of 1986 (SARA) Title III inventories.

Step 3: Characterize the hazards remaining after the screening process.

Step 4: Develop event scenarios.

Step 5: Estimate the consequences of events.

Step 6: Compare the consequences to the Emergency Classification Criteria.

Step 7: Develop EALs for those events that exceed the Alert classification criteria (see Table 4-2). These criteria apply to all types of emergency events at the Hanford Site.

\subsubsection{Use of Emergency Action Levels}

On determination that an event has occurred at or affecting a Hanford Site facility, the BED shall promptly assess the conditions, compare the indications to the facility EAL set, and determine the appropriate emergency class. Immediate actions, activation of the emergency response organization, and appropriate notifications are then carried out.

The RL-EACT is responsible for ensuring that the event has been classified appropriately by the BED and will review facility EALs to determine that the correct emergency classification has been selected. Upon activation, the EMC shall recommend, as appropriate, reclassification or termination of the event to the RL-EACT.

\subsection{CONSEQUENCE ASSESSMENT}

Consequence assessments evaluate and interpret radiological or other hazardous materials measurements or other information to provide a basis for decision-making. In this context, planning includes:

- Developing and preparing postulated scenarios and default onsite and offsite consequence projections for hazards assessment

- Developing plans and procedures for consequence assessment during an emergency

- Identifying personnel and resources to provide an effective response. 


\subsubsection{Consequence Assessment Requirements}

The Hanford Site consequence assessment activities shall provide for the following:

- Timely initial assessment of the actual or potential consequences of an emergency, including the integration of consequence assessment process with the process for categorization of an event as an emergency

- Monitoring and evaluation of the specific indicators necessary to continually assess the consequences of emergency events

- Continuous, in-depth assessment of events throughout an emergency

- Integration of the consequence assessment process with the process for determining the appropriate emergency class

- Monitoring and evaluation of specific indicators related to safety, health, environmental, and security conditions which may affect or exacerbate the emergency

- Projection of potential consequences both onsite and offsite

- Integration of the consequence assessment process with the process for protective action decision-making

- Coordination with federal, state, tribal, and local organizations to:

- Locate and track hazardous materials released to the environment.

- Estimate the integrated impact of such releases on the public and the environment.

- Locate and recover materials.

The airborne release pathway typically represents the most time-urgent situation, requiring a rapid, coordinated response. Releases to aquatic and ground pathways may not have the same time-urgency, however considerations of these pathways shall be a part of the consequence assessment activities at the Hanford Site.

4.4.1.1 Meteorological Monitoring. Representative collection of meteorological data is currently required to support environmental monitoring activities for ensuring that Hanford Site operations involving airborne releases of hazardous material comply with applicable federal, state, and local environmental protection laws and regulations, executive orders, and internal department policies. Characterization of atmospheric transport and diffusion conditions (e.g., wind speed, wind direction, stability) in the vicinity of the Hanford Site facilities is essential for consequence assessments of airborne releases of hazardous materials. Other meteorological conditions (e.9., precipitation, temperature, and atmospheric moisture) are important to environmental surveillance activities (both routine and nonroutine) such as air concentration and ground deposition monitoring. 
4.4.1.2 Water/Groundwater Monitoring. The water/groundwater monitoring and environmental surveillance programs required by DOE Order 5400.1 (DOE 1990) shall be used to characterize transport and diffusion of accidental releases of hazardous materials to aquatic pathways in the vicinity of a Hanford Site facility.

\subsubsection{Event Scene Consequence Assessments}

These assessments will be conducted at the event scene by the ECP staffs. The ECP staff should continuously evaluate the environmental conditions for inhabitants of the command post and relocate the command post as necessary.

\subsubsection{Area Consequence Assessments}

It is necessary to evaluate the consequences of releases of radioactive and nonradioactive materials at locations beyond the immediate vicinity of the event scene. This is typically within a Hanford Area (100K, 300, 400, etc.) and includes all areas outside of the event scene and within the immediately affected Area. The types of evaluations that should be conducted are those that affect the ability of operations staffs to safely shutdown operational facilities, those that affect the ability of residents to take protective actions, and those that affect the habitability of the ECC. This activity would typically be directed by the Area ECC in coordination with the EMC for impacts to other Hanford Site populations.

\subsubsection{Coordination of Consequence Assessment Results}

The UDAC has the primary responsibility for overall onsite and offsite consequence assessment for the Hanford Site. UDAC staff shall continuously assess event conditions, such as:

- release source terms

- mitigation efforts

- onsite and offsite field team data

- meteorological conditions.

State-of-the-art tools shall be used to predict the consequences of a release of hazardous materials. The results of these calculations are shared with onsite and offsite emergency responders and appropriate PARs are disseminated to affected individuals.

RL shall make provisions for representatives of the states of Washington and Oregon to participate in the consequence assessment, field team coordination and offsite protective action recommendation development process. 
DOE/RL-94-02, Rev. 0

This page intentionally left blank. 


\subsection{PROTECTIVE ACTIONS}

An important part of the emergency management program at the Hanford Site is the planning for physical measures that may be needed to protect workers and the public from adverse health affects resulting from the release of hazardous materials. This section describes the areas that may be impacted and the protective actions that may be needed.

\subsection{EMERGENCY PLANNING ZONES}

Emergencies at the Hanford Site facilities may require actions only on the Hanford Site or may affect offsite areas. The Hanford Site emergency management program uses the EPZ concept to focus emergency planning activities. The EPZs are designated areas, based upon hazards assessments, in which protective actions may be required.

The extent of a planning zone is based on the distance that a particular substance could expect to be dispersed in a particular form. The two types of exposure "pathways" for both radiological and nonradiological hazardous materials are:

- Plume Exposure Pathways: Exposure to a passing cloud, or plume, of the substance resulting in direct contact of the substance with the exterior of the body or through inhalation of the substance.

- Ingestion Exposure Pathway: Dispersal of the substance to various internal organs following the ingestion (eating or drinking) of contaminated foodstuffs or water.

The RL shall develop EPZs, as determined necessary by hazards assessments, and submit them to affected states and the cognizant Program Senior Official for approval.

\subsubsection{Plume Exposure Pathway Emergency Planning Zones}

The extent of the plume exposure EPZ for radiological hazards is based on the area within which there would be the potential for exposure by the following two modes:

- Inhalation exposure from the passing radioactive plume

- Whole body external exposure to beta or gamma radiation from the plume and from deposited radioactive material.

The extent of the plume exposure EPZ for nonradiological hazardous materials is based on the area within which there would be the potential for exposure by the following two modes:

- Inhalation from the plume

- Skin or eye contact with the plume. 
Either of these exposure routes could dominate, depending upon the toxicological and physicochemical characteristics of the hazardous material.

The plume exposure pathway EPZ includes the area of the hazardous material spill, areas immediately surrounding the spill or relesse, and downwind areas projected to receive significant concentrations of hazardous materials. The plume exposure EPZs are described in Table 5-1:

Table 5-1. Hanford Site Emergency Planning Zones.

\begin{tabular}{|c|c|c|}
\hline LOCATION & $\begin{array}{l}\text { TYPE OF HAZARD (RADIOACTIVE with SOURCE; } \\
\text { Or NONRADIOACTIVE with CHEMICAL) }\end{array}$ & RADIUS OF ZONE \\
\hline 100KE/KW AREA & NONRADIOACTNE (Chlorino) & 8.0 KILOMETERS/6.0 MILES \\
\hline 100N AREA & NONRADIOACTIVE (Chlorino) & 8.0 KILOMETERS/3.0 MILES \\
\hline 1000/DR AREA & NONAADIOACTIVE (Chlorina) & 8.0 KILOMETERS/5.0 MILES \\
\hline 200 EMW AREA & RADIOACTIVE Weoto Tenk Fecility) & 10 KILOMETERS/10 MILES \\
\hline 300 AREA & $\begin{array}{l}\text { RADIOACTIVE }(324,325,327 \text {, and 308-W } \\
\text { Fecillitica) }\end{array}$ & $\begin{array}{l}\text { 6.0 KILOMETERS/3.0 MILES } \\
\text { (Correoponding to the WNP-2 } 10 \\
\text { Mile EPZ on the South) }\end{array}$ \\
\hline 400 AREA & RADIOACTIVE (Roactor) & 7.2 KILOMETERS/4.6 MILES \\
\hline
\end{tabular}

Figure 5-1 shows the EPZs for facilities on the Hanford Site with potential offsite consequences.

\subsubsection{Ingestion Exposure Pathway Emergency Planning Zone}

The ingestion exposure pathway EPZ for radiological and nonradiological incidents for all Hanford Site facilities corresponds to the 50-m le (80-kM) EPZ for Supply System WNP-2. The principal exposure from this pathway would be from ingestion of contaminated water or foods such as milk, fresh vegetables, or aquatic foodstuffs. Facility, onsite, and offsite populations may be subject to exposure through the ingestion exposure pathway. The ingestion EPZ is shown on Figure 5-1.

Offsite protective actions within the ingestion exposure pathway EPZ are the responsibility of the counties and the states. The States of Washington and Oregon are responsible for developing and applying derived intervention levels for implementation of protective actions within the ingestion planning zone. These intervention levels are based on Food and Drug Administration guidelines and are described in the states procedures. The intervention levels are stated in terms of concentrations of radioactivity on the ground, in the soil, and in vegetation, milk, and water. 
DOE/RL-04-02, ROV. 0

Figure 5-1. Hanford Site Emergoncy Planning Zones.

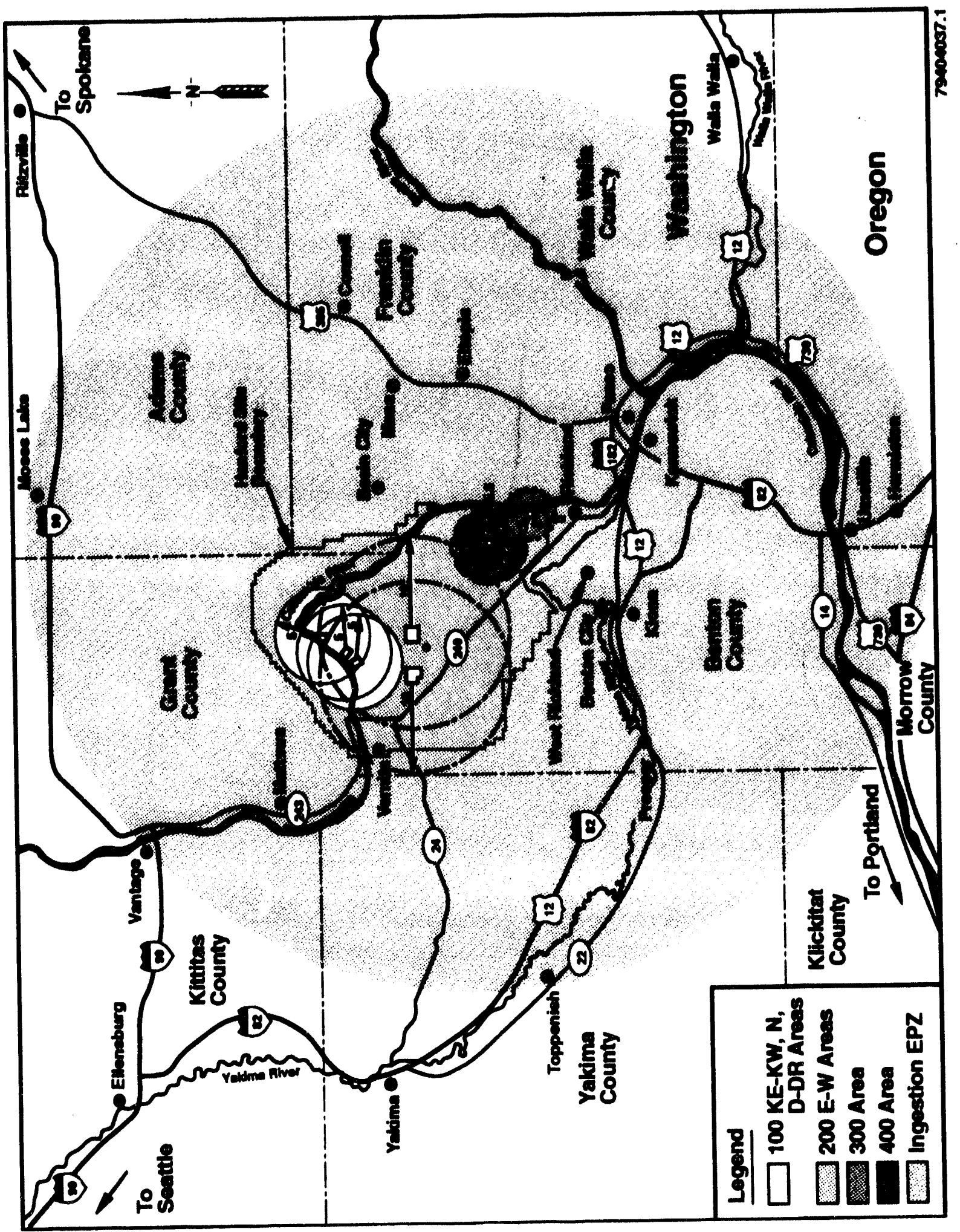




\section{B.2 PROTECTIVE ACTIONS}

Protective actions are those actions taken to preclude or reduce the exposure of individuals to hazardous materials following an accidental release at the Hanford Site. Protoctive actions may be required onsite and offsite, and include:

- Evacuation

- Sheltering

- Docontamination

- Relocation

- Access control

- Food control

- Personal protective equipment

- Administration of drugs.

\subsubsection{Protective Action Guides}

PAGs are used to determine the appropriate protective action recommendation. The RL directs the use of the PAGs adopted by the states of Washington and Oregon, which are based on the PAGs published in the EPA 400 manual, Manual of Protective Action Guides and Protective Actions For Nuclear Incidents (EPA 1992). These PAGs are intended to apply to projected doses from exposures from airborne releases of radiosctive materials and subsequent depositions during the early, intermediate, and late phases of an accident. The pathways considered include external gamma and beta dose from direct exposure to airborne materials and from deposited material, and the committed dose to internal organs from inhalation of radioactive material.

The projected dose values for initiating protective actions (evacuation or sheltering) specified by the states of Washington and Oregon is $1 \mathrm{rem}$, where the projected dose represents the sum of the effective dose equivalent (EDE) resulting from exposure to external sources and the CEDE from all significant inhalation pathways during the early phase. The PAG values for committed dose equivalent to the thyroid and the skin are 5 and 50 times larger, respectively.

The EPA PAGs are stated in terms of projected dose. Dose incurred prior to initiation of protective action (and after the early phase of an event) are not normally included when considering whether or not to take protective actions. In other words, it is intended that the PAG values be compared to the dose that can be avoided by taking protective actions.

The term "PAG" used in this plan shall mean:

- A projected dose equivalent of 1 rem to standard man, where the projected dose equivalent is the sum of the EDE from exposure to external sources and the CEDE from inhalation during the early phase.

- A projected committed dose equivalent to the infant thyroid (adult thyroid for onsite workers) of 5 rem. 
- A projected dose equivalent to the skin of 50 rem.

Response levels corresponding to these PAGs shall be derived for the specific radionuclides, foodstuffs, and animal feeds of interest according to the Food and Drug Administration (FDA) recommendations.

\subsubsection{Emergency Respones Planning Guidellnes for Nonradiological Releases}

The Hanford Site has adopted the ERPGs developed and approved by the American Industrial Hygienists Association (AIHA). The ERPGs shall be used to determine the appropriate emergency class for exposures to nonradiological releases. Those chemicals for which no ERPG value is assigned by the AlHA will have Hanford Site-specific ERPG values assigned by HEHF, as necessary. Within the ERPG system, three values are defined for each material, as follows:

5.2.2.1 Emergency Response Planning Ouidelines (ERPG-1). The maximum airborne concentration below which it is belleved that nearly all individuals could be exposed for up to one hour without experiencing other than mild transient adverse health effects or perceiving a clearly defined objectionable odor.

5.2.2.2 Emergency Response Planning Ouidelines (ERPG-2). The maximum airborne concentration below which it is believed that nearly all individuals could be exposed for up to one hour without experiencing or developing irreversible or other serious health effects or symptoms that could impair their abilities to take protective action.

5.2.2.3 Emergency Response Planning Guidelines (ERPG-3). The maximum airborne concentration below which it is believed that nearly all individuals could be exposed for up to one hour without experiencing or developing life-threatening health effects.

For purposes of applying the DOE Order 5500.2B emergency class definitions, the terms, "ERPG" and "appropriate ERPG exposure levels" shall mean: a peak concentration of the substance in air that equals or exceeds the published ERPG-2 value for that substance.

If ERPG or the Hanford Site ERPG values have not been published for a substance of interest, the following hierarchy of concentrations shall be used as a substitute (see Table 5-2).

\subsubsection{Onsite Protective Actions}

5.2.3.1 Shutdown of Operations. Contractor emergency procedures shall provide for immediate emergency response actions to be taken to prevent or reduce exposures to workers and the public, such as the shutdown of operations or other operating actions. If practical, the cognizant DOE-HO Program Senior Official and the DOE-HO Emergency Management Team shall be notified prior to shutdown, or as time permits. 
DOE/RL-94-02, Rev. 0

TABLE 8-2 Exposure Criteria for Hazardous Materials

Table 5-2. Exposure Criteria for Hazardous Materials.

\begin{tabular}{|c|l|ll|}
\hline $\begin{array}{c}\text { Primary } \\
\text { Guideline }\end{array}$ & \multicolumn{1}{|c|}{$\begin{array}{c}\text { Hiorarchy of Alternative } \\
\text { Guidelines }\end{array}$} & \multicolumn{1}{|c|}{$\begin{array}{c}\text { Source of Concentration } \\
\text { Parameter }\end{array}$} \\
\hline ERPG-3 & EEGL (30 Minutes) & NAS & 1985 \\
& IDLH & NIOSH 1990 \\
\hline ERPG-2 & EEGL (60 Minutes) & NAS & 1985 \\
& LOC & EPA & 1987 \\
& PEL-C & CFR 29: $1900-1000$ \\
& TLV-C & ACGIH & 1992 \\
& TLV-TWA X 5 & ACGIH 1992 \\
\hline ERPG-1 & PEL-STEL & CFR 29: $1900-1000$ \\
& TLV-STEL & ACGIH & 1992 \\
& TLV-TWA X 3 & ACGIH 1992 \\
\hline
\end{tabular}

DEFINITIONS

EEGL Emergency Exposure Guidance Level

IDLH Immediately Dangerous to Life and Health

LOC Level of Concern

PEL-C Permissible Exposure Limit-Ceiling

TLV-C Threshold Limit Value-Coiling

TLV-TWA Threshold Limit Value-Time Weighted Average

TLV-STEL Threshold Limit Value-Short Term Exposure Level

PEL-STEL Permissible Exposure Limit-Short Term Exposure Level

5.2.3.2 Protoctive Actions for Nonessential Porsonnol. Facility management shall identify personnel that are not essential for facility operations. Nonessential personnel within areas impacted by an emergency may be required to shelter in place or evacuate. Predetermined criteria shall be developed for implementation of these protective actions. Hanfcrd Site contractors shall develop and maintain emergency procedures that provide for the timely implementation of protective actions for their personnel. These procedures shall include provisions for:

- Emergency signals to notify personnel of the action to take.

- Personnel with permanent or temporary disabilities.

- Staging areas.

- Personnel accountability.

- Transportation (where necessary). 
- Interviows of evacuated workers to obtain information about the emergency.

- Radiological and hazardous materials monitoring and decontamination of personnel and equipment.

8.2.3.3 Emergency Parsonnel Exposure Precautions. In umergency events, the general practice of keoping radiation and hazardous material exposures to emergency personnol ALARA will be followed. All emergency personnel must be equipped with adequate dosimetry devices to allow for the accurate evaluation of their exposures. Contractor emergency procedures shall be developed and maintained to direct emergency personnel during responses to unknown hazardous materials fields. Procedures shall address appropriate authorization for ontry, dosimetry, protective training, and instrumentation.

Maintenance of permanent records of internal and external radiological exposure shall be the responsibility of the Hanford Site Radiological Records Program, administered by PNL. Records are stored on a computer data base, with back-up storage on microfilm and laser optical disk. Exposure records shall be stored for 75 years. Hanford contractors shall maintain records of exposure to nonradiological hazardous materials.

5.2.3.4 Access Control. During an emergency event, access will be controlled to areas impacted by the omergency. Procedures shall be maintained to allow emergency personnel access to controlled areas as necessary. Access to an ECP or a Protected Area requires the approval of the Event Commander, the BED, the AED, or EMC Director, through coordination with the Hanford Patrol.

Contractors shall maintain access control procedures that include logging entries, providing dose assessments, and maintaining exposure records for all emergency workers.

5.2.3.5 Personnel Accountabillty. Personnel Accountability shall be conducted following implementation of protective actions to ensure that employees are properly accounted for and that the affected area has been evacuated as necessary. Accountability takes on many forms at the Hanford Site. Accountability may range from sweeps of the affected area to ensure no one remains in the impacted area, to a full accounting of all individuals in the affected area upon arrival at a designated staging area. Accountability shall be conducted within 30 minutes following implementation of protective actions (not to exceed 45 minutes). All facilitios management at the Hanford Site shall provide for an accountability system commensurate with the hazards and facility to ensure that all affected persons have been removed from the affected area.

\subsubsection{Offalte Protective Actions}

The determination for the need for offsite protective actions shall be based on dose assessments that indicate when a PAG or ERPG value may be exceeded at the Hanford Site boundary. The RL shall notify the state and the counties adjacent to the site within 15 minutes of events categorized as emergencies. The notification shall include PARs, as appropriate. 
Immediate protective actions decisions within the plume exposure pathway are the responsibility of the appropriate county. Protective actions decisions by offsite authorities within the plume EPZ may include:

- Access control

- Sheltering

- Evacuation.

Notification to populations within the plume EPZ is the responsibility of the counties and is primarily provided using the Emergency Broadcast System (EBS). Benton and Franklin County residents within the plume EPZ receive the EBS messages via tone alert radios in their homes. Grant County residents within the plume EPZ are notified to tune to the EBS vie telephone calls from the Hanford Site automated ENS. Persons on or along the Columbia River are alerted by sirens or boat patrols. County emergency plans and procedures address protective action decisions, public warning, evacuation routes, and assistance centers.

Protective actions decisions for the ingestion exposure EPZ are the responsibility of the state. The RL shall provide the states with hazards assessment data necessary to identify areas where persons must be relocated or where food control is necessary. The states will coordinate implementation of the prritective action with the impacted counties. Notification to populations with the ingestion EPZ shall be accomplished by affected counties and the states using the EBS, as appropriz:a, and nows media reports. the states.

State and county emergency workers shall follow protective guidance as established by

\subsubsection{Protective Equipment and Supplies}

Protective responses for minimizing radiological exposure and contamination include the use of protective clothing, protective respiratory equipment, and administration of a thyroid blocking agent. Each contractor's emergency procedures identify the criteria for the location and the issuance of emergency equipment and a means for its distribution.

Each contractor shall have procedures for the use of a thyroid blocking agent, potassium iodide, which is stored at several locations on the Hanford Site and offsite. Affected personnel may be directed to use the drug in the event of a release of radioiodine from WNP-2. Instructions for use of the drug shall be included at each storage location.

\subsubsection{Event Termination}

The relaxation or lifting of protective actions generally shall be based on facility conditions and consequence assessments. The RL-EACT will decide when onsite protective actions can be modified, after consultation with UDAC and the EMC. The RL-EACT will provide recommendations to affected counties and states for the relaxation of offsite emergency protective actions, i.e., evacuation or sheltering, within the plume EPZ. The states shall be responsible for decisions on relaxation of ingestion protective actions, based upon data provided by the UDAC and FTCC. 
DOE/RL-94-02, Rev. 0

This page intentionally left blank. 


\subsection{NOTIFICATIONS AND COMMUNICATIONS}

\subsection{NOTIFICATION}

Prompt and accurate emergency notifications are essential to mitigating consequences and for protecting the health and safety of workers and the public. The Hanford Site emergency notification procedures shall be developed and maintained to provide timely notice to the emergency response organizations, Site and facility workers, and offsite agencies under the most limiting set of conditions.

Notifications shall be made quickly and accurately in order to:

- Augment the Site and facility operating staff with necessary personnel to respond to the emergency.

- Activate emergency centers at a level consistent with the classification of the emergency.

- Facilitate public notification by offsite authorities and agencies which have protective-action, decision-making authority.

- Protect Site and facility personnel and emergency workers through the provision of information necessary to implement accountability and protective actions such as sheltering, decontamination, and evacuation.

Notifications and reporting shall be in accordance with DOE Orders 5500.2B, 5000.38, and any applicable federal, state, or local requirements such as the Comprehensive Environmental Response, Compensation, and Liability Act (CERCLA); the Resource Conservation and Recovery Act (RCRA); and the Emergency Planning and Community Rightto-Know Act (EPCRA). Classified and/or controlled information shall be handled in accordance with established procedures and DOE requirements.

\subsubsection{Initial Notifications}

The initial event classification shall be made by the BED. The BED shall initiate necessary notifications to onsite personnel via sirens, crash alarms, or telephone so that they may take appropriate protective actions. The BED also provides notification, using the Emergency Notification Form (Figure 6-1), to the ONC. The ONC shall then make notifications to activate the onsite and offsite emergency response organizations.

\subsubsection{Offite Notification}

Upon classification of an event as an Alert, Site Area Emergency, or General Emergency, the BED shall be responsible for ensuring that notification is made to the ONC via telephone. 
Figure 6-1. Emergency Notification Form.

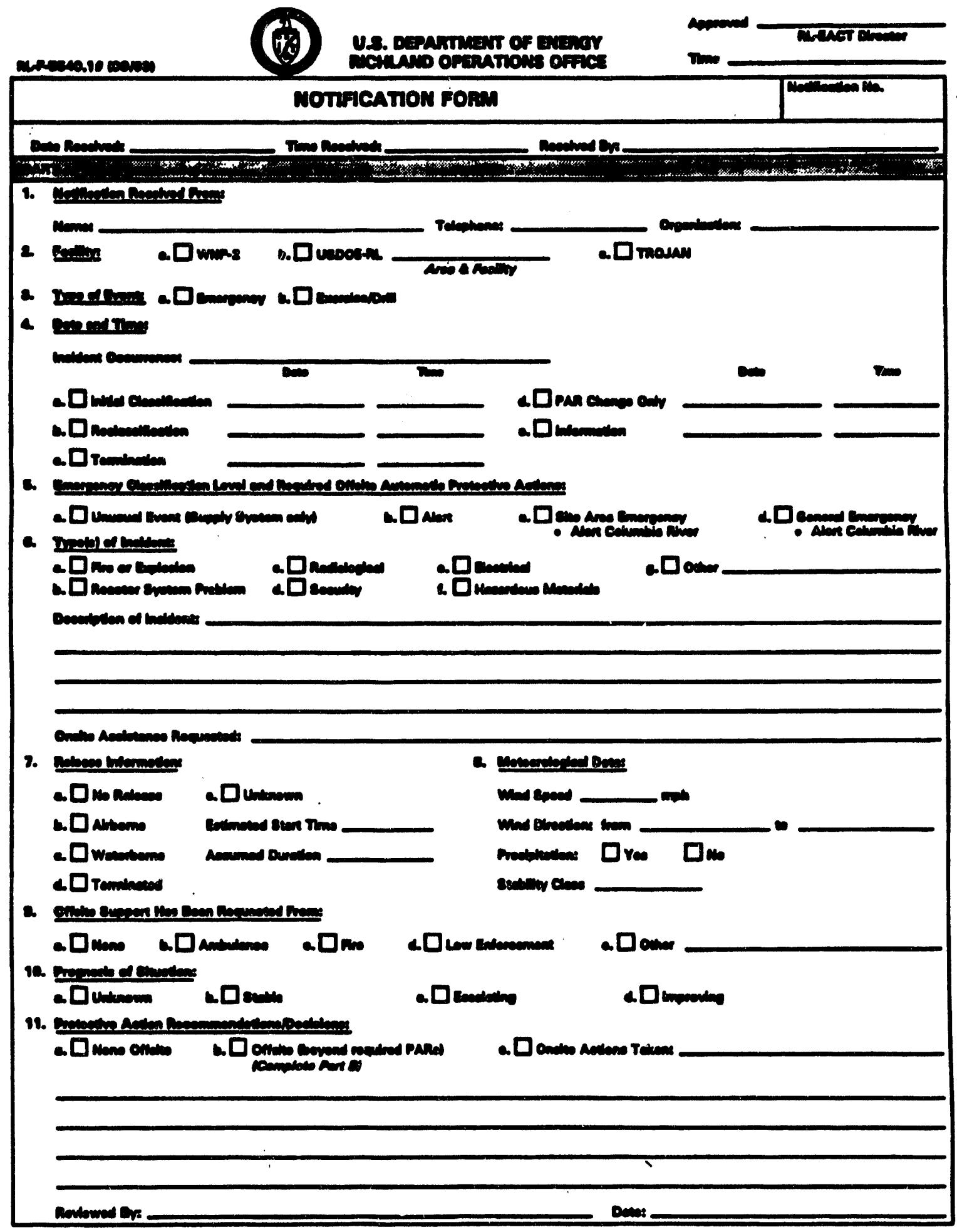




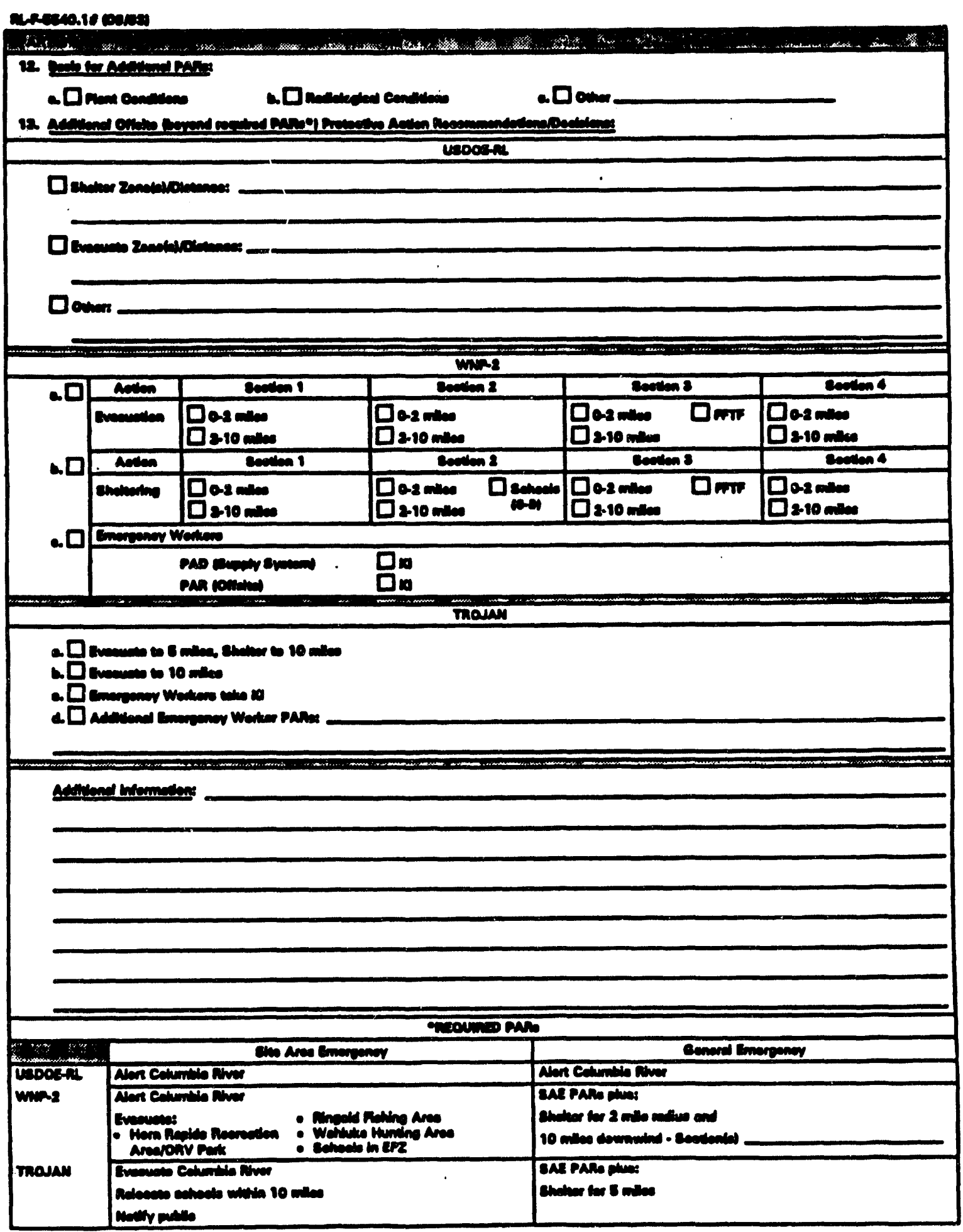


The ONC Duty Officer and available staff shall make the cifisite notifications listed below within 15 minutes of emergency classification:

- DOE-HQ Conference Call (with facility manager and RL facility representative)

- DOE Crash Telephone (hotline) which includes:

- Supply System (WNP-2)

- Benton/Franklin County EOC (dispatch)

- Washington State EOC

- Hanford POC

- Grant County EOC

- Oregon DOE.

Additionally, the ONC Duty Officer and available staff shall make the following offsite notifications after event classification, as applicable:

- Federal Aviation Administration (Site Area or General Emergency Only for Hanford Site Air Space Closure)

- Siemens Nuclear Power Corporation (PAR information only-good practice--not required)

- U.S. Environmental Protection Agency

- Washington State Department of Ecology

- Washington State Department of Health

- U.S. Department of Ecology

The RL-EACT shall have responsibility for classification of emergencies and offsite notifications upon declaration of their operability. The same offsite notifications, as listed above, and the same requirements apply anytime an event is reclassified or terminated. The same notification systems used. by the ONC will be used by RL-EACT

\subsubsection{Onsite Notffication}

Upon classification of an event as an Alert, Site Area Emergency, or General Emergency, the BED is responsible for ensuring that notification is made to the ONC via telephone.

The ONC Duty Officer and available staff will make the onsite notifications as appropriate:

- Emergency Notification System activation for appropriate ECCs

- Essential Staffing Pager Program 
- PNL Single Point of Contact

- WHC Emergency Duty Officer

- Hanford Fire Department

- HEHF Single Point of Contact.

The BED is responsible for making notifications for the purpose of onsite protective actions. These include actuating appropriate facility sirens or notifying appropriate personnel to actuate facility sirens, and notifying the POC to make crash alarm notifications and/or actuate area sirens.

\subsubsection{U.S. Department of Energy Assets}

6.1.4.1 Radiological Acsistance Program. Notifications for response to a request for radiological assistance are described in the Radiological Assistance Program Plan - Region 8.

6.1.4.2 U.8. Department of Energy National Assets. It is the responsibility of RL-EACT to determine if any national DOE assets are needed during an emergency, or to coordinate with the states if they are requesting a DOE asset. Requests for an asset will be accomplished by contacting and requesting the asset through the DOE-HQ-EOC.

\subsection{COMMUNICATIONS}

Primary and back-up means of communications shall be established and maintained to enable timely dissemination of notifications and information to onsite personnel and offsite agencies. To minimize the potential for confusion in disseminating information, the simplest, most direct system for communications should be established. The communications system shall provide for:

- Designated point(s) of contact for receipt of notifications

- Compatibility with other federal, state, tribal, and local response organizations

- Rapid dissemination of information received, to provide for timely and effective response actions.

\subsubsection{Telephone Number 911}

The Hanford Site emergency telephone number for requesting emergency response is "911." This number shall be monitored (and recorded) at all times by the Hanford Patrol at the POC. When emergency conditions exist that require responses from the Hanford F'atrol, Hanford Fire, Ambulance, or Hazardous Materials Response Team, and whenever there is any doubt as to the conditions present, 911 shall be notified. 


\subsubsection{Tolephone Number 376-2900}

This is the Hanford Site telephone number for reporting occurrences in accordance with occurrence reporting requirements. This number shall be monitored at all times by ONC personnel.

\subsubsection{Crash Alarm Tolephone System}

A crash alarm telephone system provides a medium for simultaneously relaying emergency messages and information to key personnel. The system is composed of dedicated telephones which are activated through a conference call. The crash alarm telephone systems currently provide coverage for the 200,300, and 400 Areas.

Crash alarms provide quick, reliable interactive communication of emergency messages to large numbers of individual locations and shall be used to disseminate emergency messages, as applicable. Crash alarms will be at the direction of the AED, BED/BW, or the Emergency Duty Officer.

\subsubsection{Emargency Notfication Syatem}

The ENS provides a medium for rapidly relaying emergency messages and information to key emergency personnel by the use of a computerized calling and message-delivery system, with the capability to record selected responses. The emergency notification system is currently used to notify/activate emergency center response personnel. The ENS shall be initiated by an ONC Duty Officer.

\subsubsection{Priority Message System}

The priority message system or management bulletin is a network of cc:Mail and/or facsimile machines used to disseminate information to Hanford Site employees.

\subsubsection{Radios}

Multiple radio systems and frequencies ere available for emergency communications. All operate through a repeater station on Rattlesnake Mountain to provide sitewide communications capability.

Radio transmissions, as well as mobile telephone communications, are conducted over frequencies monitored not only by Hanford Site contractors, but also by non-DOE personnel and the general public. Extra precautions shall be taken to prevent communication of serisitive information during regular and emergency communications (such as names and speculative information). 
DOE/RL-94-02, Rev. 0

\subsubsection{Evant Command Post Communications}

The ECP shall have communications to facilities outside of the affected event scene. Methods of communication include the use of:

- Commercial telephone (adjacent buildings should be identified where commercial telephones are available).

- Portable and/or fixed radio with capability to transmit on the Hanford Site safety net, Hanford Patrol, or Hanford Fire frequencies.

- Cellular telephone.

\subsubsection{Emergency Control Center Communications}

The Site ECCs shall have appropriate methods of communications including backup communications. These shall include:

- Commersial telephone.

- Portable and/or fixed radio with capability to transmit on the Hanford Site safety net, Hanford Patrol, or Hanford Fire frequencies.

- Cellular telephone.

Additionally, two dedicated networks will be maintained. These networks are:

- DOE Crash Telephone:

- Supply System (WNP-2)

- Benton/Franklin County EOC (dispatch)

- Washington State EOC

- Hanford POC

- ONC

- RL-ECC

This system will be used by the ONC to make initial notifications of emergency classification and PARs, and by the RL-ECC to make subsequent notifications of emergency classifications or reclassification, PARs, and emergency termination.

- ECC/EMC Hotline:

- RL-ECC

- EMC

- Area ECCs

This system is the primary method to communicate event information between the various emergency centers. 


\subsubsection{8ccure Communications}

Secure communications in the RL-ECC shall be accomplished, as necessary, using the Secure Telephone Unit III (STU-III) telephone system. This system enables establishment of a secure, closed network for voice communications.

\subsubsection{Emorgenoy 8lonals}

Table 6-1 lists the Standard Site Emergency Signals, their meanings and normal response actions.

Table 6-1. Standard Emergency Signals.

\begin{tabular}{|l|l|l|}
\hline \multicolumn{1}{|c|}{ Signal } & \multicolumn{1}{|c|}{ Meaning } & \multicolumn{1}{c|}{ Actions } \\
\hline AH-00-GA Horn & Nuclear Criticality & $\begin{array}{l}\text { Run at least 100 feet from } \\
\text { building; proceed to staging } \\
\text { area. }\end{array}$ \\
\hline Gong & Fire & $\begin{array}{l}\text { Vacate building; move } \\
\text { upwind. }\end{array}$ \\
\hline $\begin{array}{l}\text { Steady tone on } \\
\text { whistle, klaxon horn, } \\
\text { or siren }\end{array}$ & Area Evacuation & $\begin{array}{l}\text { Vacate building, go to } \\
\text { ovacuation staging area. }\end{array}$ \\
\hline $\begin{array}{l}\text { Wavering siren or short } \\
\text { blasts on whistle, klaxon } \\
\text { horn or siren }\end{array}$ & Shelter (take cover) & $\begin{array}{l}\text { Proceed to shelter or stay } \\
\text { indoors. }\end{array}$ \\
\hline $\begin{array}{l}\text { Stsady ringing of crash } \\
\text { alarm telephone }\end{array}$ & Emergency communications & $\begin{array}{l}\text { Pick up phone and listen; } \\
\text { relay message to } \\
\text { emergency response } \\
\text { personnel. }\end{array}$ \\
\hline
\end{tabular}




\subsection{EMEROENCY MEDICAL SUPPORT}

\subsection{INTRODUCTION}

This section describes the emergency medical responsibilities and actions for the types and severity of injuries specific to Hanford Site emergencies, as identified by consequence assessments, as well as those normally associated with industry.

The RL shall ensure that capabilities exist on the Hanford Site for emergency medical aid, triage, and decontamination. Due to the potential for injuries to be accompanied by radiological contamination, agreements with offsite facilities, shall be maintained to ensure provision of emergency medical services not provided on the Site (sec Appendix B).

\subsection{EMERGENCY MEDICAL RESPONSIBILITIES}

\subsubsection{Hanford Environmental Hoalth Foundation}

The HEHF provides and coordinates occupational health and emergency medical support for the Hanford Site. The Site Medical Director is responaible for oversight of emergency medical services at the Hanford Site. The Medical Director also interfaces with the local medical community, as appropriate. The HEHF physicians, nurses, physicians assistants, psychologists, and support staff provide medical expertise for all types of medical emergencies, as required. Specific emergency medical procedures and protocols shall be maintained by the Site Medical Director.

\subsubsection{Hanford Fire Department}

The Henford Fire Department staff, including Emergency Medical Technicians (EMTs) and paramedics, provide onsite first-response medical treatment. Ambulance services and event scene control for fire and medical accidents or incidents are also provided by the Hanford Fire Department.

\subsubsection{Other Hanford Site Contractors}

Contractor health physics and radiation protection technologists and/or industrial hygienists provide decontamination for injuries, as appropriate. Hanford Site contractors also provide support for transportation, security, notifications, communications, etc., as described in Section 2.0. 


\subsection{MEDICAL EMEROENCY CATEOORIES}

Medical emergencies are divided into four categories with assoclated levels of response. Response actions for fatalities are considered separately unless they happen as a part of a larger incident (e.9., mass casualty).

\subsection{1' Catogory 1: Mass Casualty}

Mass casualty is defined as an incident involving more than five people with serious injuries. Initial response is provided by the Hanford Fire Department EMT/paramedics. Additional levels of response will depend on the type of incident.

\subsubsection{Category 2: Contaminated Injury}

Injuries involving potential internal radiological contamination require HEHF nuraing support for the administration of appropriate pharmaceutical agents (e.g. chelating agents). Notification of the incident is provided to the nearest HSC by the Hanford Fire Department. Health physics technicians (radiation control), exposure evaluators (bioassay sampling), and additional HEHF medical support are required for trestment of internally radiologically contaminated patients.

Chemically contaminated injuries may or may not require specialized treatment. The HEHF medical organization shall provide support to first responders, Hanford Fire Department paramedics/EMT's, or local hospitals for chemical contamination injuries, as required.

\subsubsection{Category 3: Job Accident/lnjury}

Emergency medical care for job related injuries not involving contamination shall be provided by the Hanford Fire Department. Hanford Fire Department shall coordinate with the HEHF medical organization to ensure appropriate medical management of the patient(s) and completion of necessary investigation and reporting.

\subsubsection{Category 4: Other Emergency Medical}

Other emergency medical situations relate more to personal injury not directly associated with occupation; for example, heart attack, insulin shock, or car accident. Emergency medical care and transportation shall be provided by the Hanford Fire Department. The HEHF medical organization provides emergency medical care when appropriate. 


\subsubsection{Fatallitios}

The Slte Medical Director shall ensure coordination of triage, decontamination (when neceseary), coronar notification, and temporary morgue arrengements for fatalities associated with categories 1 and 2 above. The Hanford Fire Department shall be responsible for disposition of fatalities for categories 3 and 4 above as stated in Section 13.0 of the Hanford Fire Department Emergency Medical Services Program Plan (WHC-EP-O575) (WHC 1992).

\subsection{MEDICAL EMEROENCY FACILITIES AND EQUIPMENT}

\subsubsection{Emergency Decontamination Facllity}

The EDF is located north of Kadlec Modical Center in Richland. It is an unoccupied, hardened facility designed to provide for decontamination, treatment of internal contamination, and minor medical treatment for nonserious or nonlife-threatening radiologically contaminated injuries.

\subsubsection{Health Service Conters}

The HSCs are located in the following areas: 100N, 200E, 200W, 300, 400, 700, and 3000. All stations are occupied at least 7:30 am to 4:00 pm weekdays. The 200 East is a 24-hour station, seven days per week. All centers are staffed by HEHF medical staff to treat patients that do not require hospitalization.

\subsubsection{Site Decontamination Equipment}

Decontamination equipment is available at a number of locations on the Hanford Site. Equipment or facilities range from eye washes, showers, and skin decontamination kits, to a mobile hazardous materials decontamination unit operated by the Hanford Fire Department.

\subsubsection{Medical Emergency Equipment}

Equipment to support rescue and/or extrication of casualties shall be maintained by the Hanford Fire Department. Equipment for cardiopulmonary resuscitation, cardiac defibrillation, and advanced cardiac life support is maintained by both HEHF and the Hanford Fire Department. Supplies and equipment for the management of trauma are maintained by the Hanford Fire Department. Supplies for triage are available aboard each Hanford Fire Department ambulance. 


\subsubsection{Modied Emorgenoy Tranoportation}

Ambulances shall be maintained and operated by the Hanford Fire Department. Provisions shall be made for air transportation of contaminated patients to medical facillties for apecialized medical treatment, as necessary. Transportation support beyond that provided by the Hanford Fire Department shall be coordinated through the EMC.

\subsubsection{Modical Emargenoy Communications}

Communication links between medical aid and triage teams, fire and rescue units, hospitals, local (including Hanford Patrol) and state police, and RL-ECC have been established. Cellular phones, radios, and land-line phones are used for medical emergency communications.

\subsubsection{Offalte Medical Facllities}

Casualties may be transported to the following higher-level treatment facilities:

- Our Lady of Lourdes Health Care Center

- Kennewick General Hospital

- Kadlec Medical Center.

The RL maintains agreements for the care of radiologically contaminated Hanford Site personnel with these hospitals.

The RL shall ensure the provision of training and exercise support related to the services provided to the Hanford Site. The HEHF shall provide medical expertise on radiological and chemical exposure decontamination and treatment, as requested. 


\subsection{RECOVERY AND REENTRY}

This section describes the responsibilities for termination, reentry, and recovery planning and operations.

\subsection{TERMINATION OF THE EMERGENCY}

When the event has been stabilized onsite, hazardous material releases have been terminated, and protective actions have teen implemented, the emergency can be officially terminated. Termination occurs after all applicable criteria has been met and concurrence between the event contractor and RL has been obtained. The BED, AED, and EMC Director must confer and agree that termination can be declared and the EMC Director shall communicate the information to the RL-EACT Director.

The RL-EACT Director will make the official emergency termination declaration and instruct RL-EACT to proceed with official notification to local, state, and federal offsite emergency agencies that the emergency is terminated and the recovery phase has been initiated. Notification will be done through the RL-ECC emergency communications network. The criteria for the termination decision and the basis for relaxing offsite PARs, as applicable, will be included in the notification, as appropriate. Press releases will be prepared and disseminated through the JIC.

\subsection{REENTRY}

Reentry is the act of reentering an evacuated area for the purpose of performing emergency activities or to assess facility damage for the purpose of determining if the emergency can be terminated and/or for cetermining the extent of required recovery activities. Reentry can be performed at any time before termination of the emergency and during recovery activities.

The Event Contractor will determine the accessibility of the Site areas during and after the emergency and evaluate the advisability of reentry operations. Current operating records and other essential information for evaluating the emergency may be used in making the reentry decision. The RL-EACT Director is responsible for authorizing reentry except in cases where immediate action is required for saving a life, minimizing injury, or minimizing damage. In these time-urgent cases, the BED or Event Commander will make the authorization for reentry.

The BED or Event Commander will be responsible for determining appropriate protective measures for personnel reentering the event facility or area, and for ensuring that the reentry team receives a safety briefing. Application of exposure criteria may vary, depending on whether reentry activities are related to emergency operations or for assessments or recovery operations. 


\subsubsection{Reentry Exposure Considerations}

The guiding principle is to minimize the risk of injury to those persens participating in the rescue and recovery activities; however, this principle must be balanced against the immediate objective of retrieving a deceased victim, protecting property, saving lives, or mitigating a secondary event.

The EMC Director must carefully examine any proposed actions involving further hazardous or radioactive material exposure by weighing the risks of exposure, actual or potential, against its benefits. Exposure probability, the biological consequences related to dose, and the number of people exposed are the essential elements to be evaluated in making a risk determination.

Emergency situations involving the saving of lives require separate criteria than those actions required to retrieve deceased victims or to save property. The limits for radiation exposure for reentry activities shall be in accordance with the Hanford Site Radiological Control Manual (HSRCM-1) (DOE 1992b). Limits for nonradiological hazardous materials will be established using the lowest of the following limits:

- OSHA permissible exposure limits

- American Conference of Governmental Industrial Hygienists Threshold Limit Values

- Specific Washington State Department of Labor and Industries permissible exposure limits mandated by RL (e.g., asbestos).

\subsection{RECOVERY PLANNING}

Upon termination of the emergency event, onsite and offsite emergency organizations must develop and implement plans necessary to return the affected facility and surrounding areas to normal. The RL shall direct recovery planning for Hanford Site facilities and support the offsite recovery efforts of federal, state, and local agencies.

The RL-EACT Director shall ensure that recovery planning includes coordination of necessary investigations of the event root causes and corrective actions to prevent recurrence, in accordance with RLIP 5484.1A, Environmental Protection, Safety, and Health Protection Information Reporting Requirements (DOE/RLIP 1981).

\subsubsection{Planning and Operations for Onsite Recovery}

The RL-EACT Director shall designate a Manager of Recovery Operations. This manager will assess the extent of recovery actions necessary and determine the organization needed to implement recovery operations.

The RL recovery organization shall be comprised of two teams: The Recovery Support Team and the Onsite Recovery Team. 
8.3.1.1 Recovery Support Team. The Manager of Recovery Operations shall appoint a Recovery Support Team to provide oversight for the onsite recovery effort, and information and assistance to the offsite agencies.

The Recovery Support Team should consist of sufficient staff to perform functions as applicable to the situation. Initial staff may be members of the RL-EACT, since activities performed during the recovery phase closely parallel many of the activities performed during the emergency. Responsibilities of the Recovery Support Team include:

- Discuss and coordinate recovery issues with offsite agencies.

- Coordinating response to requests for offsite assistance.

- Providing input to and review of Onsite Recovery Plan.

- Responding to technical questions from DOE-HO and offsite authorities.

- Reviewing UDAC data and providing late phase onsite PARs to the Onsite Recovery Team for inclusion in Site Recovery Plan.

- Requesting offsite Federal assistance after consultation with UDAC/DOE Representative and State Representatives.

- Review UDAC data and recommendations to formulate offsite intermediate and late phase PARs, as requested by the states.

- Coordinating press information for release to the public through the JIC or Public Affairs.

- Reviewing and coordinating employee information releases, including general information and specific information for displaced workers.

- Providing information on recovery activities to DOE-HQ, State and County EOCs.

- Making emergency procurement arrangements for offsite assistance or to implement Site Recovery Plan when directed by Manager of Recovery Operations.

8.3.1.2 Onsite Recovery Team. The RL-EACT Event Contractor Representative shall appoint an Onsite Recovery Manager, who is responsible for appointing members of the Onsite Recovery Team. The Onsite Recovery Team is responsible for the development and implementation of the Onsite Recovery Plan. The team should consist of sufficient staff to perform the functions as applicable to the situation.

The Onsite Recovery Team consists of the following functions as applicable:

- Recovery Planning: Proposes and evaluates courses of action and address other major aspects of the recovery operation. 
- Task Management/Scheduling: Identifies and plans specific tasks for implementation of the Site Recovery Plan. Monitors and coordinates the status of tasks.

- Engineering Support: Provides the support for procedure preparation, data analysis, technical support to the operations staff, and other tasks related to the technical support of recovery. Provides engineering design, materials, and the construction support needed to implement any required modification of plant structures or systems.

- Plant Operations: Routine performance of plant operations functions for the duration of the recovery.

- Safety: Assesses the extent of contamination of buildings and systems. Establishes processing and decontamination priorities based on this assessment, performs surveys, releases areas, provides radiological support for maintenance and operations, and maintains radiological and exposure records. Provides for the monitoring of hazardous chemicals. Ensures work is performed in accordunce with company safety requirements and procedures.

- Operations Support: Supports the recovery efforts in areas such as personnel, communications, transportation, and temporary office space when required. Coordinates logistical support to displaced workers as detailed in the Site Recovery Plan.

- Communications: Prepares releases for employee information, including general information and specific information for displaced workers. Provides information to the Public Affairs Director for use in dissemination to the public.

- Recorder: Maintains the Onsite Recovery Log, which will serve as a chronological record of the recovery efforts. Ensures that all records and plant data are stored in accordance with contractor records procedures.

The Onsite Recovery Menager shall direct development of a detailed Site Recovery Plan. The plan shall outline the Onsite Recovery Organization, objectives, facilities available to the organization, a schedule, disposition of displaced workers, cost estimates, and recovery actions.

The Manager of Recovery Operations shall approve the Site Recovery Plan after review by the Recovery Support Team. The Site Recovery Plan can be submitted in phases to allow initial recovery activities to take place during planning.

As recovery activities decrease, the Manager of Recovery Operations should reduce the number of personnel involved in recovery activities by combining positions. If minimal activities are taking place, consideration should be made for assigning functions to Site organizations as part of normal activities. 


\subsubsection{Planning and Operations for Offsite Recovery}

The States of Washington and Oregon are responsible for determining when the relaxation of protective messures can begin, and will make all offsite reentry and recovery decisions. The states shall coordinate all recovery activities with the affected counties, who will coordinate local public health actions and disaster assistance. Recovery actions will also be coordinated with RL. The major areas of effort for offsite recovery include:

- Maintenance of access and traffic control of contaminated areas until cleanup is accomplished.

- Imposition of control measures on possibly contaminated food and dairy products until radioactivity or chemical contaminant levels are deemed acceptable or the products are decontaminated or destroyed.

- Dissemination of public health advice for individuals with noncommercial sources of food and dairy products.

- Direction of decontamination activities, by way of natural radioactive decay, contamination removal, burial, treatment, or dilution.

- Determination of radioactivity or chemical contaminant levels by field and laboratory analysis.

- Documentation of population doses, individual doses, and environmental radioactivity or chemical contaminant levels.

- Dissemination of public information through press releases and other means.

The RL shall provide representatives to state recovery task forces, as may be established, if determined necessary by the RL-EACT Director or Manager of Recovery Operations.

A major event at the Hanford Site affecting offsite populations could involve the implementation of the Federal Radiological Emergency Response Plan (FRERP) and the Federal Response Plan (FRP). Implementation of these plans would activate several Federal Agencies including the FEMA, the EPA, Department of Agriculture, and many other agencies (including DOE) to support state and local relief and recovery efforts. Overall coordination of activities under these plans is the responsibility of FEMA.

For an event involving a facility on the Hanford Site owned by DOE, RL will become the Lead Federal Agency (LFA). The FRERP details the responsibility of the LFA. These responsibilities include:

- Assessing the emergency and providing notification to the appropriate federal, state, and local governments.

- Providing offsite monitoring, assessment, and PARs. 
DOE/RL-94-02, Rov. 0

- Providing for the release of public information on the emergency.

- Providing initial support to the state and local governments on recovery monitoring and decontamination activities. The EPA will assume these responsibilities for the long-term after receiving a pledge of support from DOE. 


\subsection{PUBLIC INFORMATION}

Public information is an integral part of the emergency management program at the Hanford Site. Information must be provided to the public and employees before, during, and after an emergency. The RL, and state and local governments share the responsibility to provide this information. The RL shall develop a public information program, including methods and procedures, to provide for:

- Education of the public and employees on what to do in the event of an emergency.

- Dissemination of accurate, timely information dưring any lovel of emergency.

- Dissemination of information to help the public and employees recover after an emergency.

Coordination with offsite agencies that have the responsibility to provide emergency warning, instructions, and information to the public is key to the success of the public information program. The RL Office of Communications shall have the lead in coordinating the RL public information program with offsite agencies. Interfaces and assistance provided to offsite agencies related to public information shall be documented in memorandums of understanding, as outlined in Section 3.0, are found in Appendix B.

\subsection{EMERGENCY PUBLIC INFORMATION ORGANIZATION}

The emergency public information organization shall be activated upon declaration of an emergency, activation of the RL-ECC, or as otherwise directed by the RL Manager or RL Director of Communications. Notification to Hanford Site personnel is accomplished via the automated emergency notification system or a call tree fan-out, as back-up. Emergency public information support to offsite responses under the RAP is addressed under the U.S. DOE Region 8 RAP Plan DOE/RL-92-49.

The emergency public information organization shall be made up of contractor and RL personnel working under the direction of the RL Office of Communications Director. Personnel assignments shall correspond as closely as possible to normal duties. Two centers within the RL-ECC have responsibilities for emergency public information: the RL-EACT and the JIC.

\subsubsection{U.S. Department of Energy Emergency Action and Coordinating Team}

The RL-EACT has overall responsibility for emergency public information. The Public Affairs Director provides direction to the emergency public information organization and reports to the RL-EACT Director. 
The Public Affairs Director and RL-ECC Nows Writer work in the RL-ECC. Communications with the JIC are accomplished by telephone and computer, with a facsimile also available. A closed circuit television system onables the RL-ECC to watch news conferences as they are conducted. Cable television service is also available in the RL-ECC for viewing of local and national news reports.

9.1.1.1 Responslbilities. The RL Communications Director serves as the Public Affairs Director in the RL-EACT and is responsible for:

- Timely and accurate release of information to the public and media.

- Advising the RL-EACT Director on actions and responses that will reduce public uncertainty.

- Approving the release of emergency public information.

- Informing DOE-HQ of emergency public information actions.

- Minimizing liabilities.

- Protecting the organization's image/credibility as they relate to emergency responses, control, and recovery.

The RL-ECC News Writer is responsible for writing the primary emergency news releases, which are approved by the Public Affairs Director.

\subsubsection{Joint Information Conter}

Public information activities at the Hanford Site are coordinated with offsite agencies through a JIC. The Hanford Site JIC is located at the Federal Building, 825 Jadwin Avenue in Richland, Washington. The JIC utilizes the Hanford Science Center, the Federal Building auditorium, portions of the lobby, and Room 158.

9.1.2.1 Information Release. Information is released in a variety of ways from a number of official sources. The emergency public information program at the Hanford Site is designed with the JIC as the single point from which emergency information is released. This allows RL, Hanford Site contractors, and offsite agencies to coordinate the accurate and timely release of public information. The JIC also coordinates the release of information with DOEHO.

The RL shall encourage the participation of impacted offsite agencies in the JIC. In addition to RL and Hanford Site contractors, the States of Washington and Oregon, and the counties within the plume EPZs of the Hanford Site have included this participation in their emergency plans. The JIC is the sole source of information to the public on the event, corrective actions and potential ramifications. Additionally, local authorities utilize the JIC as their means to provide information to the media and the public. State agencies may release information directly from the state EOC, however, it will be coordinated through and simultaneously roloased at the JIC. 
The information release functions of the JIC are:

- Coordination of news releases with affected agencies

- Conducting news conferences with participation from RL and offsite agencies

- Rumor control

- Response to telephone inquiries from the public and media

- Information to employees.

9.1.2.1.1 Nows Releases. Each agency shall develop and approve their own news releases. However, copies of proposed news releases shall be shared with all agencies to ensure accuracy and consistency of information being released. News releases will then be released to the media from the JIC.

The RL shall provide the initial news release within one hour of the emergency classification. The RL shall provide copies of all releases to DOE-HQ.

9.1.2.1.2 News Conferences. News conferences will be conducted from the JIC, with spokespersons from local, state, and affected federal agencies and RL. Conferences will be conducted, as the situation warrants, to provide an opportunity for the media to ask questions of responding agencies.

9.1.2.1.3 Rumor Control. Rumors may be identified by any member of the onsite or offsite emergency response organization. Within the JIC, the telephone teams and the media monitor are the primary identifiers of rumors. Any misinformation identified will be corrected as soon as possible through news releases, news conferences, and the telephone teams.

9.1.2.1.4 Telephone Teams. Telephone teams, staffed by RL and Site contractor personnel, will answer questions from the public and media. Telephone teams will utilize news releases, emergency broadcast messages, fact sheets, and contacts with agency JIC Representatives to provide information necessary to respond to inquiries.

9.1.2.1.5 Media Tours. Media tours of the affected area may be provided, if appropriate.

9.1.2.1.6 Information to Hanford Site Personnel. Information regarding work schedules, route closures, and other critical information are provided to all Site personnel, as priority messages from the RL-EACT Director, via electronic mail. Information to be provided to offduty personnel shall be provided through the media.

9.1.2.2 Staff Work Areas and Communications. The Joint Agency News Coordination Team, JIC News Writers, Rumor Control, and Media Telephone Teams utilize the Hanford Science Center and Room 158 for work areas. Access to these areas will be controlled once the JIC is activated. Equipment necessary for the coordination, development, and dissemination of press releases is available in these work areas. This includes computers, facsimile, and duplicating equipment.

Communications to Site personnel originates from a facility two blocks north of the JIC. The Site computer system is used to provide priority messages to employees.

Coordination and dissemination of information to DOE-HO is provided via telephone and facsimile. 
9.1.2.3 Media Work Areas, Briefing Areas, and Communications. Portions of the Federal Building Lobby shall be used as a work area for the media. Telephones will be connected in the work area for the use of the media.

News conferences will be conducted in the Federal Building Auditorium. Audio visual equipment will be available for use in the news conferences. News conferences are transmitted via closed circuit television to the JIC staff work area and RL-ECC.

The media is provided information using telephone notifications, facsimile transmission of news releases, JIC distribution of news releases and news conferences, affected areas tours (if possible), and the media telephone team.

9.1.2.4 Staffing and Responslbilities. The JIC staff shall receive initial training on the concept of operations of the JIC and their specific tasks. Retraining shall be provided annually. Additionally, team members shall participate in one exercise annually. Offsite agencies that participate in the JIC are also given the opportunity to participate in training and drills related to their functions at the JIC. Offsite agency participation is requested for one exercise per year.

The JIC staffing shall be outlined in JIC procedures and shall provide the following functions:

- The timely release of accurate and understandable information to the public and media, and for responses to public inquiries.

- Providing technical or risk-related information to spokespersons.

- Conducting news conferences with participation from RL and appropriate offsite agencies.

- Providing graphic, photographic, and video support for use in news conferences and by the media.

- Recording television and radio station broadcasts, and reviewing broadcasts for inaccuracies.

- Identifying and correcting rumors and inaccuracies.

- Producing written announcements, fact sheets, and news releasias.

- Relaying press announcements to the media, providing updates 'co the media not present at the JIC, and providing responses to incoming meóia phone queries.

- Arranging for authorized media tours during the incident.

- Reviewing, as necessary, all information released to the media or the public for classified information.

- Transmitting emergency releases, bulletins, and updates to all employees. 
The Joint Agency News Coordination Team is composed of Public Information Office Representatives of Benton, Franklin, and/or Grant Counties, the States of Washington and Oregon, and involved federal agencies. The basic function of the team is to jointly coordinate releases of information to the media and to provide accurate and timely information to the public regarding operations in their jurisdictions. They will have the opportunity to participate in all news conferences.

\subsection{PUBLIC EDUCATION}

RL shall assist the jurisdictions within Hanford Site EPZs with the development and implementation of programs to educate their residents on the actions to take in the event of an emergency at the Hanford Site.

RL shall participate in public meetings, sponsored by state, tribal, or local emergency management officials, in order to make the public aware of Hanford Site activities, the potential risk from these activities, and the Hanford Site emergency preparedness program. RL shall coordinate the provision of information on the emergency management program to the media with offsite agencies.

RL shall provide information to the public and the media for each major exercise in order to educate the local community on Hanford Site activities to test the emergency preparedness program. This information will be coordinated with local emergency management officials.

\subsubsection{Plume Emergency Planning Zone Public Education}

The State of Washington and Benton, Franklin, and Grant Counties have instituted a public education program to ensure that the members of the public within a plume EPZ of the Hanford Site are aware of the proper actions to take following notification of an emergency. The counties' programs have been identified in their emergency plans. These plans, developed cooperatively with RL and the Washington Public Power Supply System, include:

- annual distribution of an emergency information calendar for residents within the plume EPZs

- distribution of a brochure for farmers and growers

- distribution of information for special audiences such as boaters or spanishspeaking residents

- periodic public meetings

- annual surveys to determine the effectiveness of these programs.

Information provided to residents includes:

- description of the hazards

- how they will be notified 
- protective actions they may be asked to take (i.e., sheltering or evacuation)

- ovacuation routes and where to go if they are asked to evacuate

- special provisions for schools or other special facilities

- how those with special needs can get help.

\subsubsection{Ingestion Emorgonoy Planning Zone Public Education}

The states of Washington and Oregon, affected tribal organizations, and counties are responsible to provide education to residents within the ingestion EPZ. Information may include:

- description of the potential impact of an emergency on residents and the sgriculture community

- preventive measures to help avoid or reduce the impact if a release occurs

- actions to take during and after a release.

Information may be provided through the dissemination of printed materials to target audiences, conducting public meetings and providing information to the media.

\subsection{SITE PERSONNEL EDUCATION}

All RL and Hanford Site contractor personnel are provided annual training on basic emergency preparedness response procedures. Additionally, Site personnel are provided information on the specific emergency plans of their building. An emergency response guide is also provided to each employee, which describes the emergency signals, basic instructions, and the emergency response structure. By telephone, Site personnel can hear a recording of the emergency signals. Drills and exercises provide additional training for Site personnel on the specific actions of their building.

Visitors, vendors, and subcontractors are provided safety, security, and emergency preparedness information before badging and annually thereafter.

See Sections 11.0 and 12.0 for more information on Sit3 personnel education. 


\subsection{EMERCENCY FACILITIES AND EQUIPMENT}

This section identifies and describes the emergency facilities and equipment used or maintained by the RL and the Hanford Site Contractors.

\subsection{EMEROENCY FACILITIES}

This section contains a description of the RL, and contractor facilities that have been equipped for emergency control, operations, and coordination. Figure 10-1 shows the geographical location of the three onsite. ECCs, the contractor EMC, and the RL-ECC. Functions and staffing of the emergency centers are described in Section 2.0.

\subsubsection{Evant Command Post}

The ECP will be the location from which the Event Commander and staff coordinate emergency response activities at the event scene. The Event Commander shall be responsible for directing all organizations responding to an emergency.

The ECP shall be located near the event scene. Contractor procedures shall provide detailed instruction for operations at the ECP.

\subsubsection{Operations Support Conter}

An operations support center will be used in some areas, as appropriate, for staging, coordinating, and dispatching, to aid in event mitigation and support. The center is staffed by the Operations Support Center Response Team, individuals with the necessary mix of experience and expertise to respond to or mitigate emergency conditions. This team shall be dispatched and controlled by the Operations Support Center Coordinator, who shall report to the BED or AED.

\subsubsection{Area Emergency Control Center}

The various facilities and activities on the Hanford Site are designated as pertaining to one of several geographically defined areas. Area ECCs are currently designated as:

\begin{tabular}{|c|c|c|}
\hline Area & Primary & Alternative \\
\hline $\begin{array}{c}\text { Northern Areas (100,200 \& } \\
600 \text { north of Wye Barricade) }\end{array}$ & $2750-E$ Building & 1100 Jadwin \\
\hline $\begin{array}{c}300 \text { Area (300 \& 600 north } \\
\text { of Wye Barricade) }\end{array}$ & $3701-D$ Building & 1100 Jadwin \\
\hline 400 Area & 4703 Building & $3701-D$ Building \\
\hline
\end{tabular}




\section{Figure 10-1 Hanford Emergency Centers}

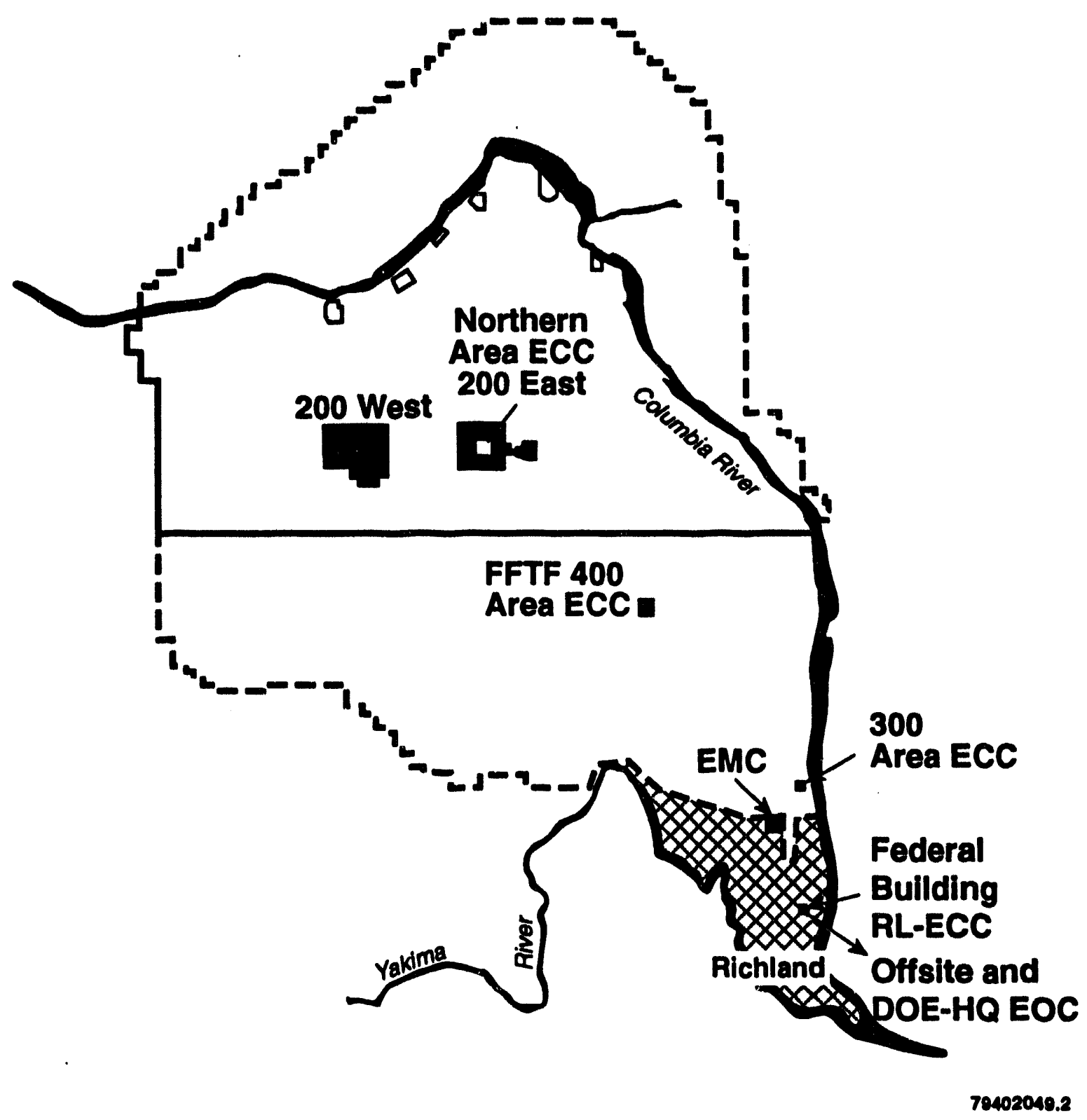



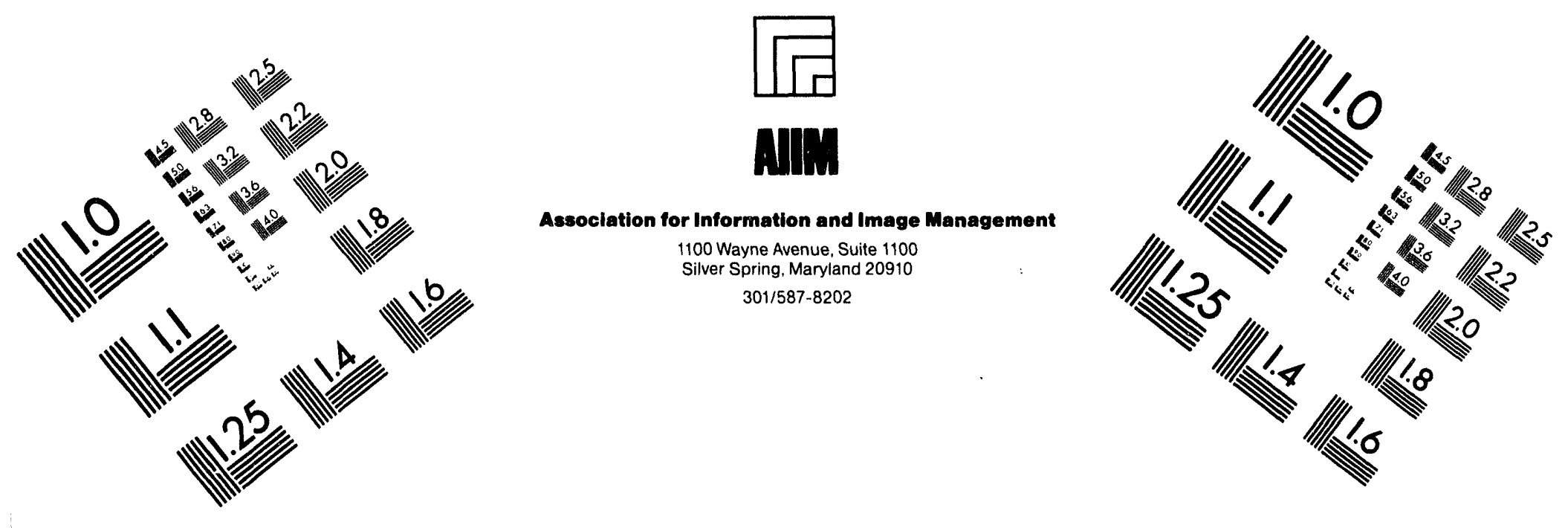

\section{Centimeter}

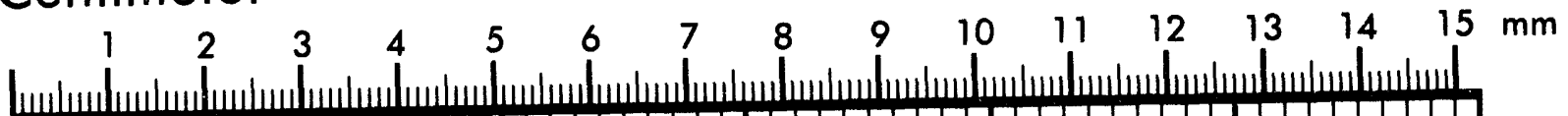

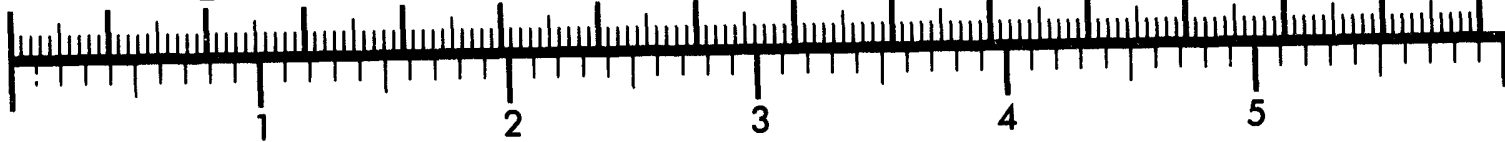
Inches
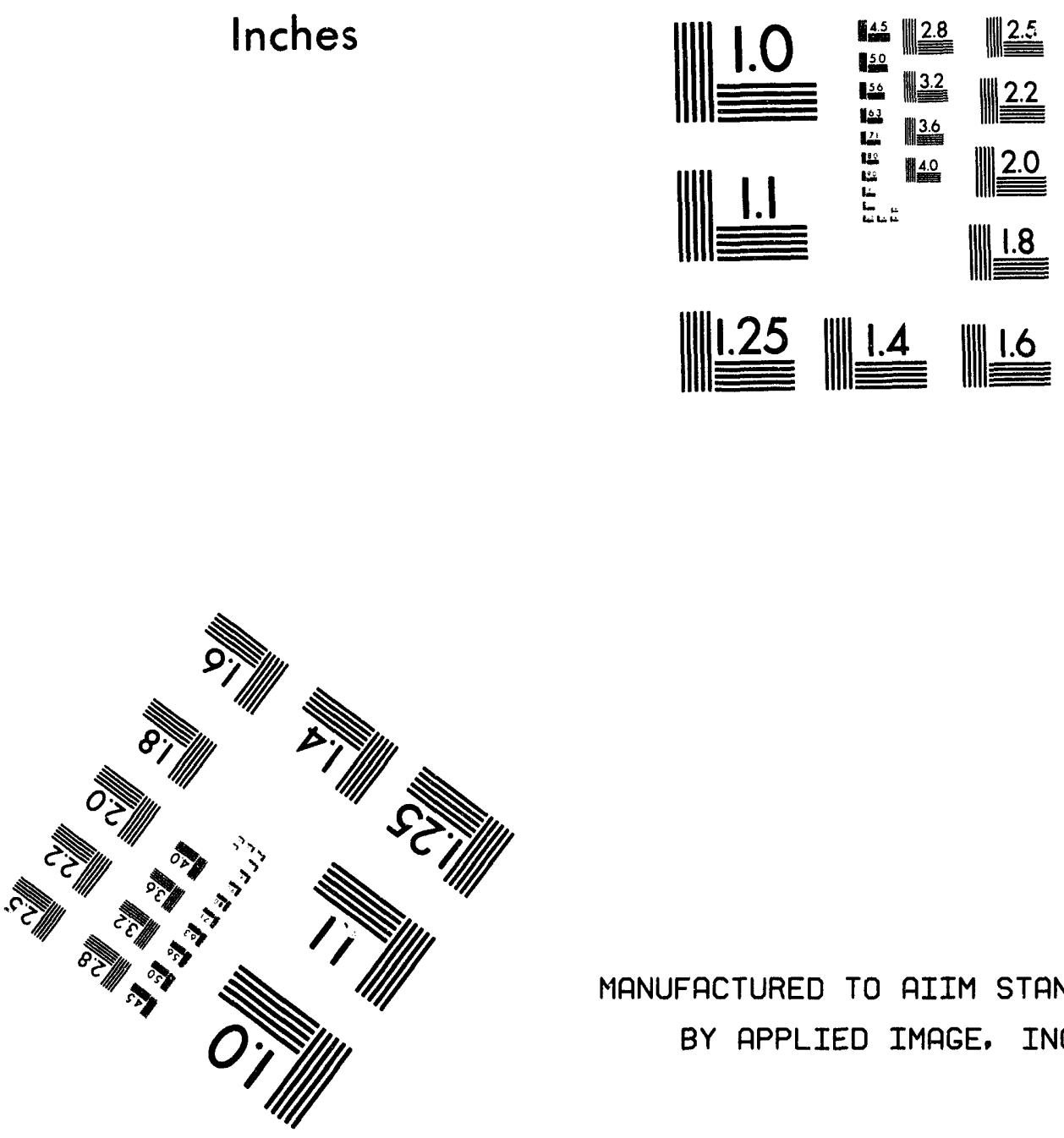

MANUFACTURED TO AIIM STANDARDS

$$
\text { BY APPLIED IMAGE, INC. }
$$

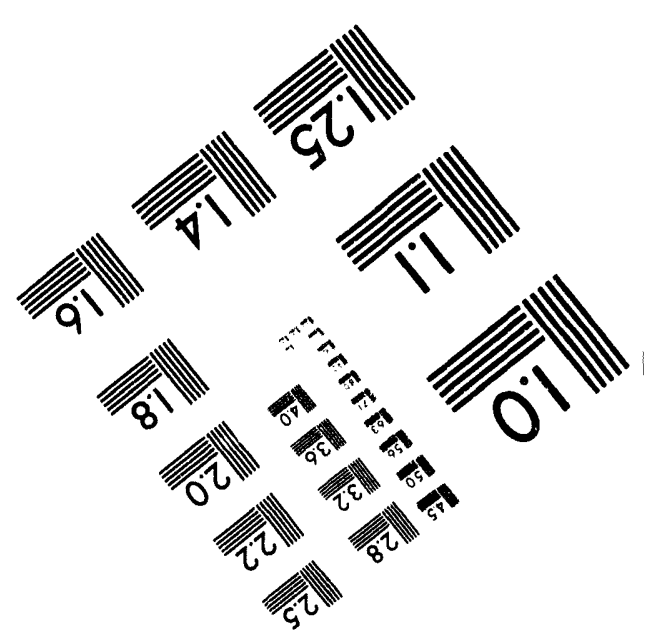



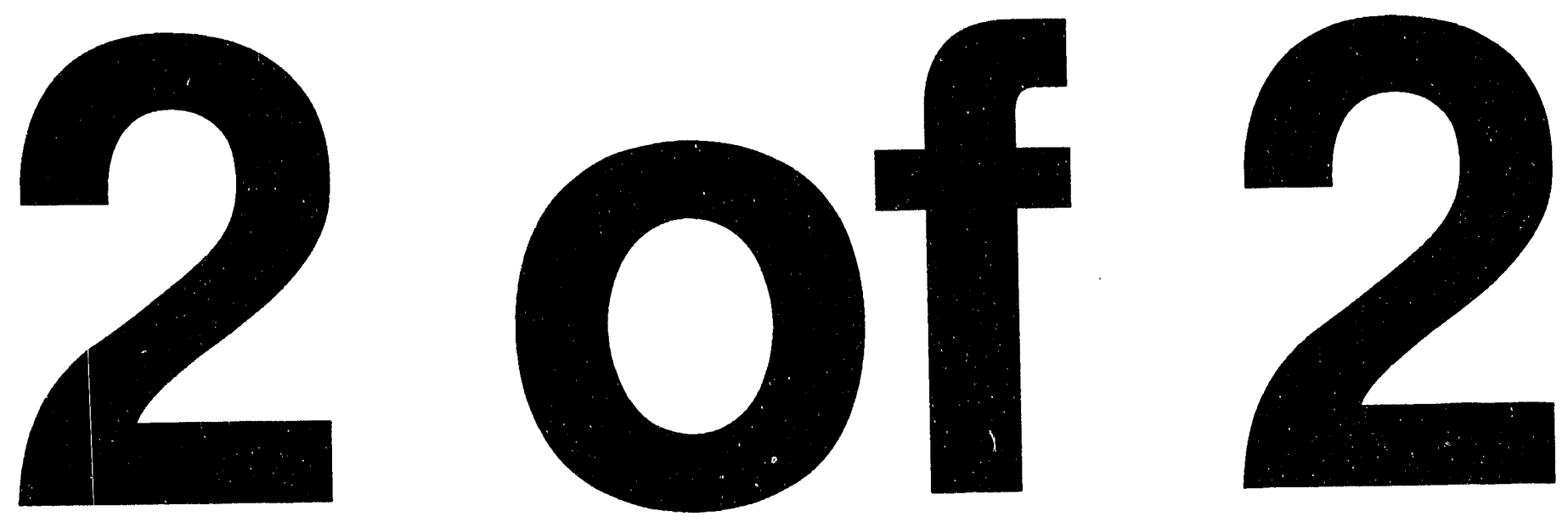
The Area ECC shall be activated upon classification of an emergency or when needed to support a building emergency organization. Staffing and equipment requirements shall be described in contractor emergency procedures.

\subsubsection{Emergency Management Conter}

The EMC is the location from which the contractor emergency management team operates. It is located in the 1170 Building. The EMC shall be activated upon classification of an alert level or higher emergency or when otherwise requested by RL or Contractor management. Staffing and equipment requirements shall be described in Contractor emergency procedures.

\subsubsection{Occurrence Notification Center}

The ONC shall be a 24-hour operational facility equipped to communicate information regarding occurrences at or affecting the Hanford Site to responsible management. The ONC personnel shall be responsible for reporting initial information to other Hanford Site contractors, the DOE, and state and local emergency management organizations. The ONC. shall be responsible for activating the Hanford Site emergency centers via the automated ENS.

\subsubsection{Hanford Patrol Operations Center}

The POC is located in the 2721-E Building in the 200 East Area. The POC monitors the Hanford Emergency Response Number (911) and business number (373-3800), and acts as the single point of contact for RL. The POC notifies and/or dispatches the following required responders:

- Hanford Fire Department

- Hanford Patrol

- Hanford Ambulance

- Hazardous Material Response Team

- Benton County Sheriff personnel assigned to Hanford Site.

The POC is also responsible for alarm monitoring, activation of crash alarms and sirens, and assisting in dispatch and radio communications for emergency responders.

\subsubsection{U.S. Department of Energy, Richland Operations Office Emergency Control Center}

The RL-ECC shall consist of the RL-EACT, the UDAC/FTCC, and the JIC. The RI-EACT, UDAC, and FTCC will be dedicated facilities located in the basement of the 703 Building, Richland, Washington. The JIC utilizes porticns of the Federal Building and the Hanford Science Center, some of which are dedicated for the JIC. The areas that are not dedicated 
can be quickly converted for JIC purposes. The RL-ECC location provides favorable proximity to the emergency management and response staff, the RL Communications Center, and to additional office space.

In the event of an Alert, Site Area Emergency, or General Emergency, the RL-ECC will be activated. The RL-ECC is outside of the plume EPZs of Hanford Site facilities thus ensuring a high probability of the RL-ECC being habitable following an emergency on the Hanford Site. An emergency power generator, routinely serviced and maintained by the General Services Administration, is available to supply power to essential emergency equipment in the Federal Building in the event of loss of normal power.

\subsubsection{Alternate Emergency Control Center}

An alternate RL-ECC has been established in a commercial building at 7601 West Clearwater in Kennewick, Washington. The criteria for abandonment of the RLECC will be:

- Radiation monitoring at the RL-ECC shows whole body dose rates (beta plus gamma) exceeding $0.1 \mathrm{rem} / \mathrm{hr}$ for greater than 1 hour.

$$
\text { OR }
$$

- The RL-ECC becornes uninhabitable for any other reason (e.g., earthquake or a security breach).

The alternate facility provides space for a down-sized RL-EACT to operate. Some communications equipment is not duplicated in the alternate facility and thus will be operated from the ONC for the RL-EACT. The RL-ECC may be reactivated following abandonment if the radiation dose rates decrease or other conditions change to the point where, in the opinion of the RL-EACT Director, it is safe to reoccupy the RL-ECC.

Procedures for the operation of the alternate RL-ECC are found in DOE-0223.

\subsubsection{Joint Information Center}

The JIC shall provide a single location where technical/management and public information representatives for the RL, Hanford Site contractors, and offsite agencies gather to provida information to the media and the public.

The JIC is located in the Hanford Science Center, Room 158, and the auditorium/obby areas of the Federal Building. Telecommunications, word processing, and duplication equipment is provided to support JIC participating agencies and the media. The functions and operations of the JIC are discussed further in Section 9.0 and DOE-0223. 


\subsubsection{Unified Dose Assessment Centerl Field Team Coordination Center}

The primary purpose of the UDAC is to perform hazard evaluations and provide appropriate PARs to the RL-EACT and Hanford Site facilities. The UDAC is a dedicated facility located in the 703 Building, adjacent to the RL-EACT in the 703 Building, and the FTCC in the 703 Building. One room houses the majority of the UDAC staff, and the other houses the FTCC and the EMS Support Manager, as well as the documents, supplies, and equipment necessary for UDAC and FTCC operations and activities. The UDAC/FTCC will be activated automatically for events classified at the Alert level or above, along with the RL-EACT. The UDAC also can be activated for other events, without other sections of the RL-ECC being activated.

The alternate UDAC/FTCC location is co-located with the RL-ECC in a commercial building at 7601 West Clearwater in Kennewick. Washington. A description of UDAC/FTCC functions can be found in Section 2.0. The UDAC/FTCC operating procedures are found in DOE-0223.

\subsubsection{Medical Emergency Facilities}

Capabilities for medical aid, triage, and personnel decontamination shall be available onsite. Emergency Medical Support is described in Section 7.0.

- Health Service Centers: The HSCs are located in the following areas: $100 \mathrm{~N}$, 200E, 200W, 300, 400, 700, and 3000. All stations will be occupied from 7:30 a.m. to 4:00 p.m. weekdays. The 200 East HSC is a 24-hour station, open seven days per week. The centers shall contain sufficient medical supplies to treat patients who do not require hospitalization. Ambulance service will be provided by the Hanford Fire Department.

- Site Decontamination Facilities: Personnel decontamination sites are located in several locations in the 100,200,300, and 400 areas.

- Emergency Decontamination Facility: The EDF is located north of Kadlec Medical Center. It is a dedicated, hardened facility designed to accommodate nonserious or nonlife-threatening radiologically contaminated injuries.

Agreements shall be in place between the RL and local hospitals for backup medical treatment (see Appendix B).

\subsubsection{Protective Clothing Cleaning}

Interstate Nuclear Services provides laundry services for the Hanford Site. The laundry facility is located in the Science and Technology Park south of the Site. The laundry manages protective clothing, including cleaning both radioactively contaminated laundry and noncontaminated laundry. 


\subsubsection{State and County Emergency Operations Centers}

The Benton County EOC is located in the basement of the Kennewick City Hall, 210 West 6th Avenue, Kennewick, Washington. Benton and Franklin Counties operate from the Benton County EOC during an emergency at the Hanford Site or WNP-2.

The Grant County EOC is located in the Grant County Court House in Ephrata, Washington.

The Washington State EOC is located in the office of the Washington State Emergency Management Division, 4220 East Martin Way, Olympia, Washington.

The Oregon State EOC is in the office of the Oregon Emergency Management Division, located at 595 Cottage Street Northeast, Salem, Oregon.

\subsection{EMERGENCY EQUIPMENT}

Emergency and backup equipment (including monitoring devices) shall be located in readily accessible areas away from the scene of the potential accident. Equipment shall be available (as appropriate) to provide the following functions for the potential credible emergencies identified.

- Emergency dosimetry

- Personnel protection

- Monitoring of personnel, facilities, and the environment onsite and offsite

- Emergency medical treatment onsite

- Meteorological evaluation

- Handling of personnel contaminated with radioactive or toxic materials, and fatalities

- Supplying emergency power, water, and sanitation

- Emergency transportation for personnel evacuation

- Movement of earth or heavy loads

- Emergency communications, including portable and secure communications equipment, as required.

To ensure equipment reliability, emurgency equipment should, to the extent practical, be the same equipment used for routine operations. The RL and the Hanford Site contractors maintain a variety of light and heavy equipment and supplies that could be diverted from routine use to emergency use, if needed. 
All equipment that could be used in an emergency response is listed in the RL Property System data base which can be quickly accessed to determine the current status of each piece of equipment. This system is maintained and operated by the Resource Allocation and Management group of the operating contractor.

\subsubsection{Assessment Equipment}

Emergency equipment shall be available, as appropriate, to allow an early and reliable determination of the seriousness of an accident. The equipment for both emergency and continuing assessment of the facilities and environment at the Hanford Site consists of dosimeters, criticality detectors and alarms, and effluent and environmental monitoring equipment. Each building having a potential for a nuclear accident has a list of dosimeters, criticality detectors, and alarms, as well as a drawing showing their location in relation to prominent facility features.

Arrangements are in place for aerial surveillance and monitoring through UDAC.

10.2.1.1 Nuclear Accident Dosimeter. The Hanford Site nuclear accident dosimeter is a stationary device that provides neutron and gamma dose information following a criticality or high-level radiation event. The dosimeter satisfies the requirements for an emergency dosimetry system by providing a system capable of determining:

- The neutron dose (in rads)

- The photon dose in the presence of neutrons (from 10 to 10,000 rads)

- The neutron flux in each of five energy intervals, which permits calculation of the neutron dose equivalent in rem.

These dosimeters are recovered only when directed by RL. Pacific Northwest Laboratory maintains a current list of nuclear accident dosimeter locations in PNL-MA-583 (PNL 1990). Instructions for recovery of these dosimeters are contained in contractor emergency procedures.

10.2.1.2 Emergency Kits and Instrumentation. Kits containing a variety of radiation monitoring instruments, forms, and equipment are available for use in an emergency.

The kit container is sealed with a lead-and-wire type seal which indicates the integrity of the inventory but which is easily broken when access to the material is required. Kits are installed throughout the Hanford Site for ready access.

Pacific Northwest Laboratory maintains these kits, which contain protective apparel, instruments, and equipment for personnel decontamination and other immediate emergency needs, at many locations throughout the Hanford Site. The instruments within these kits are rotated with the regular pool of instruments and are calibrated and maintained on a routine schedule. These supplies and the equipment are to fulfill immediate needs only, during the initial stages of an emergency. 
Under emergency conditions, many needed supplies and equipment would be drawn from the instrument and equipment pool used for normal operations at the Hanford Site. This ensures that multiple sources of supplies are available and that the equipment is calibrated, maintained, and ready for use by personnel involved in controlling the emergency.

\subsubsection{Decontamination Operation Equipment}

The 221-T Building in the 200 West Area provides equipment decontamination services for the Hanford Site.

\subsubsection{Evacuation Buses/Vehicles}

The BEDs shall ensure that vehicles are available to move all personnel from their facility. This may be accomplished by a combination of government-owned and private vehicles. If insufficient vehicles are available, evacuation buses and sufficient drivers shall be available as required to transport all building occupants.

10.2.3.1 Maintenance and Testing of Emergency Evacuation Buses. The BEDs of facilities with emergency evacuation buses assigned to their facilities are responsible for ensuring that sufficient trained bus drivers are available to move all buses on day shift and to move all employees on other shifts. The building emergency plan for facilities with buses assigned shall include an accurate listing of qualified drivers and shall be updated annually. Emergency evacuation buses are to be started and driven in accordance with maintenance requirements. A monthly inspection report shall be completed for each bus and maintained by the responsible BED.

\subsubsection{Hanford Patrol}

Hanford Patrol maintains a large inventory of security response equipment, including transportation, weaponry, protective equipment and communication.

\subsubsection{Hanford Fire Department}

The Hanford Fire Department maintains a large inventory of fire-fighting, hazardousmaterial-response, and rescue equipment. The Hanford Fire Department also operates the Hanford Site ambulance service from various area fire stations. Mutual aid agreements with local fire departments provide additional backup capabilities. 


\subsection{MAINTENANCE AND TESTING OF ALARM AND COMMUNICATION SYSTEMS}

The Facility manager or BED shall ensure that preventive maintenance is performed on the following equipment by the responsible maintenance organizations, in accordance with established preventative maintenance procedures:

- Area/building evacuation alarms

- Area/building take cover alarms

- Area public address systems (if used for emergency evacuation instructions).

Contractor Emergency Preparedness shall conduct monthly tests of:

- Safety net base stations and Emergency Center radios

- The WHC emergency control center communicator telephone line connecting the northern, 300, and 400 Area ECCs and the EMC.

Other preventive maintenance and testing requirements are as shown.

- At least once a month, contractors shall conduct an operational test of each area crash alarm (200 East, 200 West, 300, and 400).

- Quarterly tests of the ENS.

- Emergency Preparedness shall test the 300 Area single-point-of-contact 376-5000 crash alarm on the last Monday of the month.

Area and building evacuation and take cover alarms shall be audibly tested at a predesignated time each month. This requirement shall be incorporated into preventative maintenance programs. The evacuation siren and the take cover siren shall be tested for 15 to 30 seconds each. Announcements of the tests will be made during the weekly crash alarm tests, where applicable.

\subsection{INVENTORY OF EMERGENCY EQUIPMENT}

Contractor emergency equipment shall be inventoried periodically, in accordance with contractor inventory control procedures, to ensure availability in the event of an emergency.

A quarterly inventory of emergency equipment in emergency centers shall be conducted and the records of these inventories maintained for one year by the contractor responsible for emergency center maintenance. An implementing procedure for conducting emergency center inventories shall be maintained and corrected within $\mathbf{3 0}$ days of an inventory change. 
DOE/RL-94-02, Rev. 0

This page intentionally left blank. 
DOE/RL-94-02, Rev. 0

\subsection{TRAINING}

In addition to training that Site personnel receive on their day-to-day functions, an emergency preparedness training program shall be established and structured to ensure Hanford Site emergency response organization readiness.

\subsection{TRAINING REQUIREMENTS}

The Emergency Preparedness training program shall include a mix of classroom instruction, tabletop exercises or walkthroughs, and drills. A formal training program shall be in place for the instruction and qualification of all personnel (primary and alternate) who comprise the Hanford Site emergency response organization. Training programs shall be systematic and performance based; with emphasis on team training and facility-specific emergency response scenarios.

Annual retraining for the emergency response organization shall include lessons learned from past drills and exercises, changes to plans and procedures, and lessons learned from emergencies at DOE and other industrial facilities.

Training shall be provided annually to workers who may have to take protective actions in the event of an emergency. This may be provided through general employee training and/or participation in drills/exercises.

\subsection{TRAINING PROGRAM EVALUATION}

Emergency Preparedness training programs shall include evaluation methods to ensure that all emergency response personnel are trained in the program elements pertinent to their position and are able to respond effectively in an emergency.

The programs shall also contain self assessment activities that analyze overall training program effectiveness. Results of self assessment activities will be utilized to upgrade and improve the Emergency Preparedness training program. 
DOE/RL-94-02, Rev. 0

\subsection{EMERGENCY PREPAREDNESS COURSES}

\begin{tabular}{|c|c|c|c|}
\hline Course Type & Frequency & Audience & Summary \\
\hline $\begin{array}{l}\text { Emergency Center } \\
\text { Training }\end{array}$ & $\begin{array}{l}\text { Before } \\
\text { assignment and } \\
\text { annually } \\
\text { thereafter }\end{array}$ & $\begin{array}{l}\text { Emergency } \\
\text { Center staffs }\end{array}$ & $\begin{array}{l}\text { Training is for staff } \\
\text { assigned to RL and } \\
\text { Contractor emergency } \\
\text { centers and provides } \\
\text { overview of emergency } \\
\text { response organization, } \\
\text { and specific center } \\
\text { operation. }\end{array}$ \\
\hline $\begin{array}{l}\text { Building Emergency } \\
\text { Organization }\end{array}$ & $\begin{array}{l}\text { Before } \\
\text { assignment and } \\
\text { annually } \\
\text { thereafter }\end{array}$ & $\begin{array}{l}\text { Building } \\
\text { emergency } \\
\text { organizations } \\
\text { (i.e., BEDs/BWs } \\
\text { and support } \\
\text { staff) }\end{array}$ & $\begin{array}{l}\text { This training is provided } \\
\text { to members of the } \\
\text { building emergency } \\
\text { response organization } \\
\text { and addresses } \\
\text { emergency procedures, } \\
\text { responsibilities, and } \\
\text { command and control. }\end{array}$ \\
\hline $\begin{array}{l}\text { General Employee } \\
\text { Training }\end{array}$ & Annually & $\begin{array}{l}\text { All DOE and } \\
\text { Contractor } \\
\text { Employees }\end{array}$ & $\begin{array}{l}\text { This training is provided } \\
\text { to all employees on } \\
\text { basic emergency } \\
\text { preparedness response } \\
\text { procedures. }\end{array}$ \\
\hline $\begin{array}{l}\text { Visitor/Nendor } \\
\text { Subcontractors }\end{array}$ & $\begin{array}{l}\text { Before badging } \\
\text { and annually } \\
\text { thereafter }\end{array}$ & $\begin{array}{l}\text { Hanford Site } \\
\text { visitors/ } \\
\text { vendors }\end{array}$ & $\begin{array}{l}\text { This training is provided } \\
\text { to visitors/vendors and } \\
\text { subcontractor personnel } \\
\text { and provides safety, } \\
\text { security, and emergency } \\
\text { preparedness } \\
\text { information. }\end{array}$ \\
\hline
\end{tabular}

\subsection{RECORD KEEPING}

The Emergency Preparedness training programs for the Hanford Site will include a consistent, auditable method for maintaining training records. The system will include a means for tracking attendance, and a system for reminding employees when training is needed.

The system will be incorporated into contractor/Site central training record organizations when possible. 


\subsection{VISITORS/VENDORS}

All visitors and vendors, contractors, and consultants must receive an orientation regarding safety, security, and emergency preparedness requirements while on the Hanford Site. This orientation is required once every 12 months and is offered on a drop-in basis in the same area where the security badges are issued. A security badge will not be issued unless the visitor/vendor is in compliance with this requirement.

Visitors to the Site will receive a brochure containing safety, security, and emergency preparedness information when the security badge is issued.

\subsection{OFFSITE TRAINING SUPPORT}

No offsite training support has been identified to substitute existing emergency preparedness training courses. However, emergency response personnel shall participate in training opportunities offered by other field elements or offsite agencies that may benefit the emergency response organization.

\subsection{OFFSITE PERSONNEL TRAINING}

Training programs will be offered to offsite organizations that perform emergency tasks described in this plan, as appropriate. Training may include facility-specific orientations, hazards information, and emergency response procedures. The training will be provided in support of and in conjunction with the counties, tribes, and states at their request.

The RL and the Supply System offer training to offsite medical support groups, including ambulance and hospital personnel, for the handling and care of radiologically contaminated patients. The Supply System has the lead role for this training with RL contractors providing support to them.

\subsection{INSTRUCTOR TRAINING AND QUALIFICATION}

The emergency preparedness training programs shall identify and document instructor qualifications for their courses. Emergency Preparedness Program Managers have the responsibility for qualification of instructors for each course offered. The qualification process shall identify both experiential and/or academic requirements for instructors. 
DOE/RL-94-02, Rev. 0

This page intentionally left blank. 


\subsection{DRILLS AND EXERCISES}

Drills and exercises will be used to train workers and validate the emergency management program. Each member of the Hanford Site emergency response organization shall participate in a drill or exercise at least annually to demonstrate proficiency in response duties.

\subsection{DRILLS}

Drills shall be used to train personnel in their responsibilities and procedures, in the use of emergency equipment, in team interactions, and in coordinating their organization with other emergency response organizations.

The Hanford Site drills shall be of sufficient scope and frequency to ensure the development and maintenance of adequate response capability. Emergency response functions which may be demonstrated through drills include:

- Notification

- Emergency communication

- Fire

- Medical emergencies

- Hazardous material detection and monitoring

- Environmental sempling and analyses

- Security

- Personnel accountability

- Evacuation

- Emergency categorization

- Decontamination

- Facility activation

- Public information

- Health physics

- Bomb search

With the concurrence of the Area Emergency Preparedness Representative, drills may be combined (using credible scenarios), and response to actual events may be documented, to meet drill requirements. Evaluations and written critiques shall be prepared following all drills. An annual integrated drill schedule shall be issued by the contractor emergency preparedness organization before the fiscal year starts.

\subsubsection{Facility Drills}

BEDs or BWs shall be responsible for the conduct and documentation of required facility drills, in accordance with contractor procedures.

While the primary responsibility for the building's drill program lies with the BED/BW. Contractor Emergency Preparedness will review drill scenarios and schedules, and ensure 
coordination with potentially affected organizations. At least one independent observer (e.g., Emergency Preparedness Area Representative) should be obtained for each drill. The BEDs/BWs will prepare predrill report forms for participating organizations. Post-drill reports will be provided to contractor emergency preparedness within two weeks after a drill.

Corrective actions resulting from facility drills will be tracked and resolved by the BEDs/BWs. Verification of corrective action completion and effectiveness, will be conducted by contractor Emergency Preparedness during facility appraisals and surveillances.

\subsubsection{Emergency Center Drills}

Emergency Center drills will be conducted quarterly. All staff assigned to the emergency centers shall participate in a drill at least every year, according to the requircments of DOE Order 5500.3A. Additionally, offshift notification tests shall be conducted via the ENS to determine staffing availability.

Emergency Center staff shall respond to a no-notice activation drill once per year. Drills will document response times and minimum staffing requirements. Actual Emergency Center activations may be used to meet this requirement.

\begin{tabular}{|l|l|}
\hline \multicolumn{1}{|c|}{ Emergency Center } & \multicolumn{1}{|c|}{ Drill Frequency/Criteria } \\
\hline Area Emergency Control Centers & $\begin{array}{l}\text { Quarterly/offshift staff availability } \\
\text { Yearly/no-notice activation }\end{array}$ \\
\hline Emergency Management Center & $\begin{array}{l}\text { Quarterly/offshift staff availability } \\
\text { Yearly/no-notice activation }\end{array}$ \\
\hline $\begin{array}{l}\text { RL Emergency Control Centers } \\
\text { (RL-EACT, UDAC/FTCC, and JIC) }\end{array}$ & $\begin{array}{l}\text { Quarterly/offshift staff availability } \\
\text { Yearly/no-notice activation }\end{array}$ \\
\hline
\end{tabular}

\subsection{EXERCISES}

Exercises shall be conducted to verify and validate the adequacy of the overall emergency preparedness program. The exercise program shall:

- Conduct exercises emphasizing facility-specific emergency events and response abilities, and minimize the use of generic, nonspecific simulations

- Provide hands-on experience for emergency response personnel under simulated emergency conditions

- Maintain key skills of emergency response personnel

- Enable problems in emergency response exercises to be identified and corrected 
DOE/RL-94-02, Rev. 0

- Verify emergency response planning assumptions and validate exercise requirements in the Hanford Site Emergency Plan.

Exercise participation may be used to satisfy specific facility or functional drill or training requirements.

The Hanford Site Emergency Exercise Program organization shall administer the Hanford Site Emergency Exercise Program and is accountable for the following:

- Developing and maintaining procedures to implement the requirements of the exercise program.

- Preparing and conducting an annual tabletop and field exercise to include participation by one or more offsite agencies (e.g., DOE-HQ, tribal, local, state) and all appropriate Hanford Site emergency response organizations. The basis of the exercise scenario shall be rotated among facilities with EPZs extending offsite.

- Preparing and conducting two annual Hanford Site field exercises and four limited exercises involving only onsite emergency response organizations.

- Preparing and conducting four (one each quarter) Command Post Exercises as tabletop drills for the RL-EACT.

- Preparing and conducting annual no-notice activation drills for all Hanford Site emergency response facilities.

- Developing and maintaining an exercise five-year schedule to ensure that each reactor and hazardous facility participate in an exercise with the appropriate ECC.

- Developing and maintaining an exercise objectives matrix that defines the requirements for exercises and identifies the elements to be tested during conduct of emergency exercises.

- Developing exercise objectives to verify corrective actions from conditions identified in past audits, drills, or exercises.

- Assigning and training evaluators and controllers.

\subsubsection{Exercise Development}

Proposed goals and objectives shall be provided to RL QSH for review before an exercise. A scenario shall be developed to ensure that events occur which address the objectives. Each major exercise "draft" package shall be submitted to the Exercise Director at RL QSH for comment. The "final" exercise package shall be presented to the Exercise Director for approval. The draft and final exercise packages will include, as a minimum, the following information:

- Objectives, scope, and limitations 
- A time schedule of real and simulated initiating events

- A narrative summary of the conduct of the exercise

- A schedule for development, review, approval, and dissemination of the exercise critique.

\subsubsection{Evaluation and Corrective Action}

An exercise control organization will be assigned to ensure the exercise is conducted in a safe and secure manner in accordance with the exercise timeline. An evaluation team will be used to determine if objectives are met and identify issues to be corrected.

Each field and limited exercise scenario package shall include, as a minimum, performance objectives, evaluation criteria, and a descripiion of the anticipated responses to be evaluated.

The Hanford Site Emergency Exercise Program shall ensure that an evaluation for each drill or exercise include:

- Oral critique with affected players immediately following the exercise at each play location.

- A written critique to be provided to RL QSH (field exercises only). The written critique will identify exercise issues categorized as deficiencies, weaknesses, or improvement items.

- A means to formally track deficiencies and weaknesses to completion. Improvement items will be provided to the appropriate organization for implementation as required.

- Quarterly reports to RL QSH on the status of all formally tracked corrective actions.

\subsubsection{Offeite Coordination}

Offsite agencies, including DOE-HQ, tribal, state and local organizations, and appropriate federal organizations, shall be asked to participate in the annual field exercise and preparatory tabletop exercises. Participation by offsite agencies is dependent upon the scenario and the agencies desired level of participation.

Coordination of offsite participation shall be accomplished through a Scenario Review Group (SRG) which shall meet periodically prior to an exercise to develop the exercise scenario package. Exercise needs of offsite agencies shall be discussed with the SRG and included in the scenario, to the extent possible, without compromising the onsite exercise requirements. 


\subsection{EMERGENCY MANAGEMENT PROGRAM ADMINISTRATION}

The basic purpose of program administration is to establish and maintain effective organizational management and control of the emergency management program. The RL shall oversee, coordinate, and assess the emergency management programs of the Hanford Site contractors and will ensure the preparation and maintenance of plans and procedures necessary for RL to carry out its responsibilities during and emergency.

\subsection{EMERGENCY MANAGEMENT PROGRAM ADMINISTRATOR}

The RL Manager has the responsibility for administering the emergency menagement program for the Hanford Site. The RL Manager has delegated the authority to develop. implement, and maintain the emergency management program to the Assistant Manager for Technical Support. The Emergency Preparedness staff in the Public Safety and Medical Programs Branch of the QSH carry out these responsibilities.

Each contractor shall designate an administrator who shall be responsible for the company emergency management program and assessing the emergency program of the building emergency organizations. Each facility shall designate BEDs or BWs who are responsible for the facility emergency program. The RL Emergency Preparedness staff shall oversee, coordinate, and assess the activities of the Hanford Site contractor emergency management program administrators.

\subsubsection{Emergency Management Functions at the}

U.S. Department of Energy.

Richland Operations Office

The QSH Emergency Preparedness staff functions related to overseeing contractor emergency preparedness programs are:

- Ensuring that hazard assessments are adequately performed, documented, and updated.

- Reviewing and recommending approval of the Hanford Site Emergency Readiness Assurance Plans (ERAP) developed by contractors and RL, which shall describe tho overall program and summarize the programs of the facilities.

- Assessing facility emergency preparedness programs to verify compliance with DOE directives and policy, and provide the results/conclusions to the cognizant DOE-HQ Program Support Office. 
- As necessary, submitting order requirement exemption requ lests to the cognizant Program Senior Official, providing an alternative equivalent to, or exceeding, this order.

- Reviewing and approving the Hanford Site emergency exercise program, and reviewing written critiques of exercises and quarterly reports on corrective action status.

Emergency Preparedness functions to ensure that RL can carry out its responsibilities in an emergency are:

- Ensuring that annual budgets and mission and function statements reflect implementation policies and decisions.

- Revising and updating the Hanford Sito Emergency Response Plan and RL Emergency Implementing Procedures in accordance with DOE Order 5500.3A, and ensuring integratic $\Omega$ within the overall emergency management program.

- Interfacing with federal, state, tribal, and local emergency management agencies.

- Maintaining and negotiating agreements with state and county response agencies, federal assistance agencies, and maintaining medical and fire support agencies' agreements.

- Providing training to state and local emergency response personnel as requested.

- Recruiting and training staff for the RL-EACT.

- Maintaining the RL-EACT facility and equipment.

- Maintaining the DOE Region 8 RAP.

\subsection{EMERGENCY READINESS ASSURANCE PLAN}

The QSH Emergency Preparedness staff shall prepare and update the Hanford Site ERAP addressing planning and preparedness for emergency response for each hazardous facility. Each contractor shall submit an ERAP to RL OSH by September 30 each year for inclusion in the Hanford Site ERAP. The ERAP, and annual updates, shall be submitted to DOE-HO for approval, as required by DOE Order 5500.10 (DOE 1991c). The annual updates shall cover a planning cycle of five fiscal years from the date of the initial or updated ERAP. The ERAP shall contain information as directed in DOE Order 5500.10 and each ERAP section should be organized so as to separate the following information:

- Background material and procedures not subject to change from year to year, unless the facility, operation, or activity changes. 
- Annually updated information containing reports on the activities and accomplishments of the past year, and plans, schedules, and budgets for the next five fiscal years.

The ERAP shall serve as the baseline document for emergency readiness assurance evaluations, and as a planning tool to identify and develop needed resources and improvements.

Annual updates to the ERAP will contain the same types of information and have the same structure as the initial plan. All updated plans shall highlight any changes in planning bases, organizations, exemptions, etc., from previous ERAPs, as well as compare actual achievements to goals, milestones, and objectives.

\subsection{ASSESSMENTSIAPPRAISALS}

An annual appraisal of the emergency management program shall be conducted to assess the adequacy of contractor and RL emergency preparedness and compliance with DOE directives, the ERAP, and other requirements such as the CERCLA, the RCRA, and the EPCRA. Appraisals shall be scheduled, conducted and reported in accordance with DOE Orders 5500.10, 5482.1B (DOE 1986), and 5500.3A. Management controls shall be implemented for evaluation and correction of assessment results. These assessments shall be conducted by personnel not directly responsible during an emergency for performing the functions being assessed.

Conclusions of assessments shall be provided to the cognizant PSO through their inclusion in the ERAP.

Hanford Site contractors shall.maintain internal self-assessment programs including order compliance assessment, drills, exercises, integrated audits and appraisals, and surveillances, commensurate with their hazards. Audits and appraisals of hazardous facility emergency preparedness programs shall be conducted annually, with the documented results provided to RL. Corrective actions shall be tracked and status reports shall be provided to RL.

\subsection{DOCUMENT CONTROL}

The Hanford Site Emergency Response Plan and implementing procedures shall be controlled distribution documents. The QSH shall use a document control system to ensure that controlled copies are up to date, and are available at locations where they may be needed in an emergency. The OSH shall determine the internal and external controlled copy distribution of the emergency plan and implementing procedures. 
13.4.1 Review and Update of the Hanford Site Emergency

Response Plan and U.S. Department of

Energy, Richland Operations Office

Implementing Procedures

The emergency plan and RL implementing procedures will be reviewed annually by the $R L$ and the appropriate response organizations and agencies. The QSH is responsible for the coordination of this review and any resulting actions. The QSH will identify specific changes deemed necessary and will ensure implementation of the revisions.

Revising and updating of the emergency plan and procedures may be initiated at any time deemed necessary by QSH. All major changes and/or amendments will be approved by the RL Manager or his designee, and incorporated by the QSH.

Contractor emergency implementing procedures shall be reviewed annually and revised as necessary.

The plan and procedures will be provided to the DOE-HQ Office of Environmental Restoration and Waste Management for initial review and approval. Subsequent revisions shall be approved by the Manager of the RL. Copies of the approval/disapproval actions shall be provided to DOE-HQ. A controlled copy will be provided to the HQ-EOC.

\subsubsection{Reviow of Agreements}

Agreements with local, state, and federal officials and agencies (contained in Appendix B) are maintained by QSH and are reviewed and/or updated at least every 2 years. The agreements may be updated at more frequent intervals if necessary. Updates may be initiated either by the RL or by the agreement official or agency. Updates are documented by amendment marks on individual pages of the agreement unless comprehensive amendments are required. The agreements that have been reviewed, but not updated, will be designated by the signature of the reviewer and the review date.

\subsubsection{Classified Information}

The QSH shall ensure that emergency preparedness documents, such as plans, procedures, scenarios, and assessments are reviewed for classified and unclassified controlled nuclear information, as necessary.

\subsubsection{Supporting Documents}

The QSH shall maintain copies of documents and records which support the emergency management program; such as technical data, hazards assessments, ERAPs, and plans and procedures. Records of training, drills, exercises shall be maintained to document status of the program and provide direction for improvements. 
Hanford Site contractors shall maintain records which will provide documentation of the facility emergency preparedness program and to support the preparation of the ERAP, work plans, otc.

Arrangements have been made with the WHC Microfilm Section, Federal Building, to keep a current file of plot and floor plans that may be required during an emergency. Requests for this service during an emergency will be through the Assistant Manager for Administration, RL.

\subsubsection{Vital Records}

The vital records program at the RL ensures the protection and availability of information critical to effective emergency response management, and the protection of the legal rights and interests of citizens; federal government and employees; and DOE contractors and Site personnel. The RL Director of the Site Infrastructure Division is responsible to ensure that a Vital Records program for the Hanford Site is in place.

The vital records program is administered by the operating contractor and is reviewed ennually for effectiveness. The RL and all contractors shall annually review their respective records indicated on the Vital Records submittal listing and determine necessary additions to or deletions from the list. The QSH shall ensure that the retrieval process for vital records is evaluated annually as part of a Hanford Sitewide emergency exercise.

Each contractor and RL shall provide designated storage locations for vital records, as appropriate. Contractor and RL emergency plans and procedure and Building Emergency Plans identified as vital records shall be stored at emergency centers. Other emergency operating records and rights and interests records designated as vital need not be kept at emergency centers.

A copy of RLIP 5500.1B, Vital Records Protection Program Implementing Procedure (DOE/RLIP 1991), is provided to the Records Management Branch, Office of Controller DOE-HO.

\subsubsection{Emergency Records}

The RL and contractor emergency procedures shall provide for documentation of major communications and actions taken during an emergency. The QSH shall maintain emergency records. 
DOE/RL-94-02, Rev. 0

This page intentionally left blank. 


\subsection{REFERENCES}

Atomic Energy Act of 1954, 42 USC 2011 et seq., Public Law 83-703, as amended.

Comprehensive Environmental Response, Compensation, and Liability Act of 1980 , 42 USC 9601 ot seq.

DOE, 1993, Occurrence Reporting and Processing of Operations Information, DOE Order 5000.3B, U.S. Department of Energy, Washington, D.C.

DOE, 1992a, U.S. Department of Energy, Richland Operations Office, Emergency Plan Implementing Procedure, DOC-0223, U.S. Department of Energy, Washington, D.C.

DOE, 1992b, Hanford Site Radiological Control Manual, HSRCM-1, U.S. Department of Energy, Richland Operations Office, Richland, Washington.

DOE, 1991 a, Emergency Categories, Classes, and Notification and Reporting Requirements, DOE Order 5500.2B, U.S. Department of Energy, Washington, D.C.

DOE, 1991 b, Emergency Management Guide, U.S. Department of Energy, Washington, D.C.

DOE, 1991c, Emergency Readiness Assurance Program, DOE Order 5500.10. U.S. Department of Energy, Washington, D.C.

DOE, 1990, General Environmental Protection Program, DOE Order 5400.1, U.S. Department of Energy, Washington, D.C.

DOE, 1986, Environment, Safety, and Health Appraisal Program, DOE Order 5482.1B, U.S. Department of Energy, Washington, D.C.

DOE/RL, 1992, U.S. Department of Energy, Region 8 Radiological Assistance Program Plan, DOE/RL-92-49, U.S. Department of Energy, Richland Operations Office, Richland, Washington.

DOE/RLIP, 1991, Vital Records Protection Program Implementing Procedure, DOE/RLIP 5500.1B, U.S. Department of Energy, Richland Operations Office, Richland, Washington.

DOE/RLIP, 1981, Environmental Protection, Safety, and Health Protection Information Reporting Requirements, DOE/RLIP 5484.1A, U.S. Department of Energy, Richland Operations Office, Richland, Washington.

Emergency Planning and Community Right-to-Know Act of 1986, 42 USC 11001 et seq.

EPA, 1992. Manual of Protective Action Guides and Protective Actions for Nuclear Incidents, U.S. Environmental Protection Agency, Washington, D.C. 
FEMA, 1985, Federal Radiological Emergency Response Plan, Federal Emergency Management Agency, Washington, D.C.

FEMA, 1991, Federal Response Plan, (For Public Law 93-288, as amended), Federal Emergency Management Agency, Washington, D.C.

Uregon State Hanford Emergency Response Program, 1993, Oregon Department of Energy, Salem, Oregon.

PNL, 1990, Locations of Criticality Alarms and Nuclear Accident Dosimeters at Hanford, PNL-MA-583, Pacific Northwest Laboratories, Richland, Washington.

Resource Conservation and Recovery Act of 1976, 42 USC 6901 et seq.

Superfund Amendments and Reauthorization Act of 1976, 42 USC 11001 et seq.

Washington State Hanford Emergency Response Plan, Washington State Department of Community, Trade, and Economic Dovelopment, Olympia, Washington.

WHC, 1992, Hanford Fire Department Emergency Medical Services Program Plan. WHC-EP-0575, Westinghouse Hanford Company, Richland, Washington. 
DOE/RL-94-02, Rev. 0

\section{APPENDIX A}

\section{LAW ENFORCEMENT ASSISTANCE PLAN} (TO BE INSERTED) 
DOE/RL-94-02, Rev. 0

This page intentionally left blank. 
DOE/RL-94-02, Rev. 0

APPENDIX B

MEMORANDUM OF UNDERSTANDING

B-1 
DOE/RL-94-02, Rev. 0

This page intentionally left blank. 
DOE/RL-94-02, Rev. 0

\section{APPENDIX B}

\section{AGREEMENTS}

This appendix contains memoranda of understanding between the U.S. Department of Energy. Richland Operations Office, and the following agencies:

\begin{tabular}{|l|c|}
\hline \multicolumn{1}{|c|}{ Agency/ritle } & Page \\
\hline State of Washington & $\mathrm{B}-4$ \\
\hline Benton and Franklin Counties & $\mathrm{B}-10$ \\
\hline Grant County & $\mathrm{B}-16$ \\
\hline Washington Public Power Supply System & $\mathrm{B}-19$ \\
\hline $\begin{array}{l}\text { Washington Public Power Supply System and Hanford Enviromental Health } \\
\text { Foundation }\end{array}$ & $\mathrm{B}-24$ \\
\hline $\begin{array}{l}\text { Hanford Enviromental Health Foundation and Siemens (formerly Advanced } \\
\text { Nuclear Fuels) }\end{array}$ & $\mathrm{B}-26$ \\
\hline National Weather Service & $\mathrm{B}-28$ \\
\hline Our Lady of Lourdes Hospital & $\mathrm{B}-30$ \\
\hline Kadlec Hospital & $\mathrm{B}-32$ \\
\hline Kennewick General Hospital & $\mathrm{B}-34$ \\
\hline $\begin{array}{l}\text { Coast Guard, Washington Public Power Supply System, and Benton and Franklin } \\
\text { Counties }\end{array}$ & $\mathrm{B}-36$ \\
\hline State of Oregon & $\mathrm{B}-43$ \\
\hline Tri-Cities Mutual Aid Agreement & $\mathrm{B}-50$ \\
\hline $\begin{array}{l}\text { Mutual Law Enforcement Assistance (Example of agreements established with } \\
\text { Richland, West Richland and Kennewick Police, Benton and Franklin County } \\
\text { Sheriffs, and Washington State Patrol) }\end{array}$ & $\mathrm{B}-54$ \\
\hline
\end{tabular}


MEMORANDUM OF UNDERSTANDING

BETWEEN STATE OF WASHINGTON

AND

DEPARTMENT OF ENERGY

RICHLAND OPERATIONS OFFICE

EMERGENCY PREPAREDNESS AND RESPONSE

I. BACKGROUND AND PURPOSE

This memorandum of understanding establishes a framework of cooperation between the State of Washington and the Department of Energy, Richland Operations Office, in the planning for and response to emergencies at the Hanford Site which might have offsite consequences.

\section{RESPONSIBILITIES}

The Department of Energy's Richland Operations Office (RL) is responsible for responding to all emergencies contained within the federally operated facilities located within the Hanford Site boundaries. In the event that a Hanford emergency has offsite public health implications, $\mathrm{RL}$ and the State will coordinate implementation of their emergency plans.

RL will provide support and assistance to the State of Washington in the preparation, implementation and recovery phases of emergency responses affecting the offsite environment by:

- Coordinating the activities of Federal agencies which are parties to the Federal Radiological Monitoring and Assessment Plan (FRMAP).

- Assisting in radiological monitoring and decontamination; radiation exposure evaluation and radiation health hazards assessment.

- Providing medical advice on emergency treatment of persons exposed to radiation and technical advice on radioactive contamination.

- Cooperating with appropriate officials in the development of the State plan for coping with emergencies occurring on the Hanford Site.

III. OFF NORMAL EVENTS, EMERGENCY ACTION LEVELS AND RESPONSE ACTIONS

Off Normal Event - A non-emergency event of general public interest. RL will inform the Department of Social and Health Services (DSHS)

Radiation Control Section of such events before the close of the next working date of the event or prior to its issuance of a news release, whichever comes first.

Four classes of emergency action levels will be utilized. These classes are: (1) unusual event, (2) alert, (3) site area emergency, and (4) general emergency. The description of these classes and RL's interpretation as applicable to the Hanford Site, along with the expected response actions of RL and the State relative to each class, are as follows:

1. Unusual Event

This class is described as an unusual event in progress or having occurred which indicates a potential degradation of the level of safety of the plant. No releases of radioactive material requiring B-4 
offsite response or monitoring are expected unless further degradation of the safety system occurs.

The event involves conditions with little or no potential for offsite release of radioactive material. Events which fall into this category may include a significant unusual occurrence or other event with potential for public interest.

The purpose of notification to the State is to assure that the first step in any response later found to be necessary has been carried out and to provide current information on unusual events.

RL will inform the State of the nature of the unusual condition and close out with verbal summary within 24 hours or escalate the event to a more severe class.

2. Alert

This class is described as an event in progress or having occurred which involves an actual or potential substantial degradation of the level of safety of the plant.

This event involves conditions where limited releases of radioactivity might occur which could produce a whole body dose rate at the site boundary equal to or greater than $.5 \mathrm{mR} / \mathrm{hr}$, but not greater than $50 \mathrm{mR} / \mathrm{hr}$.

The purpose of the alert to the State is to assure that emergency personnel are readily available to respond if the situation becomes more serious or to perform confirmatory radiation monitoring, if required, and provide current status information.

RL will:

- Inform the State of alert status and reason for the alert.

- Activate its emergency control center and press center.

- Dispatch onsite monitoring teams and associated communications.

- Provide continual status updates to the State, at least at 15-minute intervals.

- Provide periodic meteorological assessments to the State, and if any releases are occurring, dose assessments for actual releases.

- Activate Unified Dose Assessment Center, perform offsite monitoring and evaluation, and provide information to the State, until the State monitoring team is activated and operating.

- Close out by verbal summary within 8 hours or escalate to a more severe class. 
When notified by RL, the State will:

- Activate its emergency operations center.

- Alert to standby status key emergency personnel including monitoring teams.

- Provide confirmatory offsite radiation monitoring and ingestion pathway dose projections, as necessary.

- Maintain alert status until verbal closeout or the event is escalated to a more severe class.

3. Site Area Emergency

This class is described as an event in progress or having occurred which involves actual or likely major failures of plant functions needed for protection of the public.

Such an event involves conditions where significant releases of radioactivity are likely or are occurring which could result in a whole body exposure rate at the site boundary equal to or greater than $50 \mathrm{mR} / \mathrm{hr}$. The projected dose at the site boundary must not exceed a 1 rem whole body dose or the event will qualify as a General Emergency.

A Site Area Emergency may be declared as a result of either of the following:

1. If it is obvious from the start that the event is going to have the defined impacts, or

2. As information on the event becomes more definitive, it becomes obvious the event is going to develop into the defined impact.

In either case, emergency radiation monitoring teams would be requested.

4. General Emergency

This class is described as an event in progress or having occurred which involves actual or imminent substantial degradation of plant safety systems.

The event involves actual or imminent significant release of radioactive material to the offsite environment which could result in a dose equal to or exceeding 1 rem whote body or 5 rem thyroid. If, during or at the beginning of an event, there is imminent danger to the public a General Emergency would be identified and immediate notifications would be made requesting immediate response actions. 
The purpose of the Site Area and General Emergency notifications to the State is (1) initiate predetermined protection actions for the public, (2) provide continuous assessment of information from RL and offsite measurements, (3) initiate additional measures as indicated by event release or potential release, and (4) provide current information for consultation with the State and the public.

For both a Site Area and General Emergency, RL will:

- Notify the State of the emergency status and reason: for the emergency.

- Activate its emergency control center and press center.

- Dispatch onsite and offsite monitoring teams and associated communications.

- Provide plant status updates at least at 15-minute intervals to the State.

- Dispatch a management representative to the Washington State Emergency Operations Center.

- Provide technical and management consultation with the State as required.

- Provide meteorological and dose assessments to the State via the Unified Dose Assessment Center.

- Close out by verbal summary within eight hours, or, if site area emergency needs to be escalated to general emergency so advise.

When notified by RL, the State will:

- Provide immediate public notification on emergency status and provide public updates.

- Activate its emergency operations center.

- Dispatch key emergency personnel including monitoring teams.

- Provide offsite monitoring results to RL through the Unified Dose Assessment Center.

- Continuousiy assess information obtained from this Center and the offsite monitoring teams with regard to changes to protective actions already initiated for public mobilizing evacuation resources or sheltering.

- Provide Public Information Officer at the RL Press Center.

- Maintain emergency status until closeout or reduction of emergency class. 


\section{AREAS OF COOPERATION}

A. Notification

1. The Department of Social and Health Services will be notified of off normal events.

2. The Department of Emergency Management will be the single point of contact for notification to the State regarding emergencies. Notification will be provided to the State within fifteen minutes after classification of the emergency, and will be based upon the emergency action levels described above.

Authentication of the notification cali to the State will be effected by a return call to RL.

B. Radiation Control and Meteorology Data

RL will conduct evaluations of radiation hazards through direct and field radiation readings within the Hanford Site and will perform offsite monitoring and evaluation until the State monitoring team is activated and operating. RL will provide radios for the State monitoring teams.

The State will provide or arrange for needed radiation monitoring outside the Hanford Site to conduct evaluations of radiation hazards through direct and field radiation readings, and to determine contamination levels of environmental samples as appropriate.

Communications and liaison of dose assessments and current status on meteorological and radiological conditions will be accomplished through a Unified Dose Assessment Center located in the Federal Building, Richland, Washington. The State will send a representative to this Center. The radiation data and monitoring activities of the offsite agencies present during an emergency wili be coordinated with the State.

C. Recovery Period

RL will provide assistance to minimize radiation health hazards, decontamination problems, etc., to the State which serves as the lead agency supporting local governments during post-accident periods.

D. Training and Exercises

RL and State should conduct an annual emergency response exercise designed to assess emergency response capabilities and provide needed training. Cooperative arrangements for such exercises and training must be agreed to in advance. 
E. Public Affairs

At the request of the State, RL will assist the State in its development of educational materiais concerning radiation and its hazards and information regarding appropriate actions to be taken by the general public in the event of an accident involving radioactive materials.

F. Ingestion Pathway

The State, with support from RL, will implement protective measures for the 20-mile ingestion exposure pathway emergency planning zone around the Hanford Site.

G. Reentry

The State, with support from RL, will continually assess the emergency situation. They will determine the extension of or when the relaxation of protective measures should begin.

H. Emergency Public Information

During an emergency, preliminary media releases from $\mathrm{RL}$ and from the State will be coordinated. For a Site Area or General Emergency, RL will activate the jnint Hanford Emergency Press Center, and the State and RL spokepersons will jointly prepare and release information statements from that location.

V. TERM OF AGREEMENT

This agreement will become effective upon signature and continue until cancelied by either party by written notice to the other. Amendments or modification to this Agreement may be made upon written agreement by both parties to the Agreement.

APPROVED FOR STATE OF WASHINGTON:

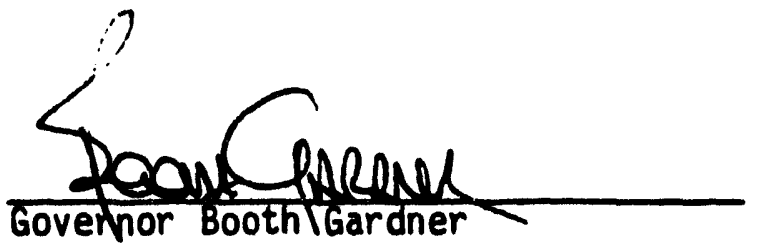

$\frac{4 \cdot 20 \cdot 85}{\text { Date }}$

APPROVED FOR THE DEPARTMENT OF ENERGY RICHLAND OPERATIONS OFFICE:

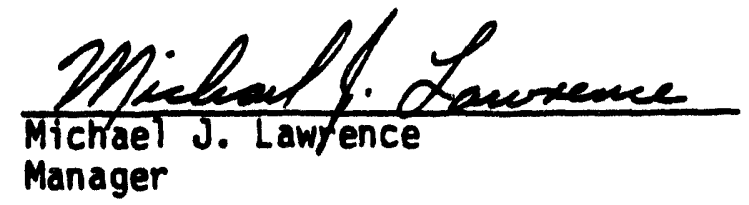

$$
\frac{4-8-85}{\text { Date }}
$$


DOE/RL-94-02, ROV. 0

\author{
MEMORANDUN OF UNDERSTANDING \\ BETWEEN \\ BENTON COUNTY, WASHINGTON \\ AND \\ FRANKLIN COUNTY, WASHINGTON \\ AND \\ DEPARTMENT OF ENERGY \\ RICHLAND FIELD OFFICE \\ EMERGENCY PREPAREDNESS AND RESPONSE
}

I. BACKGROUND AND PURPOSE

This memorandum of understanding reaffirms the established framework of cooperation among Benton County and Frankl in County located in the State of Washington and the Department of Energy (DOE) Richland Field Office in the planning for, and response to, emergencies at the Hanford Site which might have offsite consequences.

\title{
II. RESPONSIBILITIES
}

The DOE Richland Field Office (RL), is responsible for responding to all emergencies contained within the federally operated facilities located within the Hanford Site boundaries. In the event that a Hanford emergency has offsite public health implications, RL and the Counties will coordinate implementation of their emergency plans. RL will provide support and assistance to the counties in the preparation and implementation of emergency responses affecting the offsite environment by:

- Coordinating the activities of Federal agencies which are parties to the Federal Radiological Monitoring and Assessment Plan (FRMAP).

- Assisting in radiological monitoring and decontamination, radiation exposure evaluation, and radiation health hazards assessment.

- Providing medical advice on emergency treatment of persons exposed to radiation and technical advice on radioactive contamination.

- Coordinating with appropriate officials in the development of the Counties' plan for coping with radiological incidents occurring on the Hanford Site.

III. OPERATIONAL EMERGENCIES AND RESPONSE ACTIONS

Operational emergencies may involve such things as reactor or nonreactor facilities, and safeguards and security matters.

Three classes of operational emergencies will be utilized. These are: (1) Alert, (2) Site Area Emergency, and (3) General Emergency. The description of these classifications and RL's interpretation as 
applicable to the Hanford Site, along with the expected response actions of RL, and the Counties relative to each classification, are as follows:

1. Alert - An Alert represents events in progress or having occurred which involve an actual or potential substantial reduction for the level of facility safety and protection. Any environmental releases of hazardous materials are expected to be limited to small fractions of the appropriate Protective Action Guideline (PAG) or Emergency Response Planning Guideline (ERPG) onsite.

The purpose of the notification of the Alert by RL to the Counties is to assure that emergency personnel are readily avallable to respond if the situation becomes more serlous or to perform confirmatory monitoring, if required, and provide current status information.

RL will activate its Emergency Plan, to include provisions to:

- Promptly notify the Benton County Emergency Dispatch Center of the Alert status and reason for the Alert.

- Activate its Emergency Control Center and Joint Information Center.

- Dispatch onsite monitoring teams and associated communications.

- Provide status updates to the Benton and Frankl in Counties Emergency Operations Center (EOC), at periodic intervals.

- Provide periodic meteorological assessments to the Benton and Frankl in Counties EOC, and, if any releases are occurring, dose estimates for actual releases.

- Activate the Unified Dose Assessment Center, perform offsite monitoring and evaluation, and provide information to the Benton and Franklin Counties EOC until the State of Washington monitoring team is activated, operating, and assumes responsibility.

- Close out by verbal summary within eight hours after conclusion of event or, if appropriate, escalate to a more severe classification.

When notified by RL, Benton County will activate its applicable emergency plan, to include provisions to:

- Notify the Franklin County Emergency Dispatch Center.

- Activate its Emergency Operations Center.

- Provide liaison between RL, and Frankl in County in coordinating the required actions by Frankl in County. 
- Alert to standby status key emergency personnel.

- Maintain iliert status until verbal closeout or the event is escalated to a more severe classification.

When notified by the Benton County Emergency Dispatch Center, Frankl in County wi]l:

- Coordinate necessary actions with Benton County.

- Alert to standby status key emergency personnel.

- Maintain Alert status until verbal closeout or the event is escalated to a more severe classification.

\section{Site Area Emergency}

A Site Area Emergency represents events which are in progress or have occurred involving actual or likely major failure(s) of facility safety or safeguards systems needed for the protection of onsite personnel the public health and safety, the environment, or national security. Any environmental releases of hazardous materials are not expected to exceed the appropriate PAGs or ERPGs offsite.

\section{General Emergency}

A General Emergency represents events which are in progress or have occurred that involve actual or imminent catastrophic fallure of facility safety systems with potential for loss of confinement integrity, catastrophic degradation of facility protection systems, or catastrophic fallure in safety or protection systems threatening the integrity of a weapon or test device which could lead to substantial offsite impacts. Any environmental release of hazardous materials can reasonably be expected to exceed the appropriate PAGs or ERPGs offsite.

The purpose of the Site Area and General Emergency notification by RL to the Counties is to (1) initiate predetermined protective actions for the public, (2) provide continuous assessment of information from RL and offsite measurements, (3) initiate additional measures as indicated by event release or potential release, and (4) provide current information for consultation with the Counties and the public.

For both a Site Area and General Emergency, RL will implement its Emergency Plan, to include provisions to:

- Promptly notify the Benton County Emergency Dispatch Center of the emergency status and the reason for the emergency.

- Activate its Emergency Control Center and Joint Information Center.

- Dispatch onsite and offsite monitoring teams and their associated communications. 
- Provide status updates to the Benton and Franklin Counties EOC at periodic intervals.

- Provide periodic press briefings.

- Provide technical and management consultation to the Benton and Franklin Counties EOC as required.

- Provide meteorological and dose estimates to the Benton and Franklin Counties EOC.

- Close out by verbal summary within eight hours after conclusion of event, or, if the Site Area Emergency needs to be escalated to General Emergency, so advise.

When notified by RL, Benton County will implement its applicable emergency plan, to include provisions to:

- Notify the Franklin County Emergency Dispatch Center.

- Provide liaison between RL and Franklin County for Franklin County's required actions.

- Provide immediate public notification about the emergency status and provide public updates.

- Activate its Emergency Operations Center.

- Dispatch key emergency personnel.

- Continuousiy assess information obtained from $\mathrm{RL}$, with regard to changes to the protective actions already initiated for public evacuation and/or sheltering.

- Provide a Public Information Officer at the Joint Information Center.

- Maintain emergency status until closeout or reduction of emergency classification.

When notified by the Benton County Emergency Dispatch Center, Franklin County will:

- Provide immediate public notification of the emergency status and provide public updates.

- Establish a joint Emergency Operations Center with Benton County.

- Dispatch key personnel.

- Maintain emergency status until closeout or reduction of emergency classification. 


\section{AREAS OF COOPERATION}

\section{- Notification}

The Benton County Emergency Dispatch Center will be the single point of contact for notification to Benton and Frankl in Counties. Notification will be based upon the emergency classification levels described above. Authentication of the notification call to the Counties may be effected by a return call to RL.

- Radiation Control and Meteorology Data

Communications and liaison of dose assessments and current status about meteorological and radiological conditions will be accomplished through the RL Emergency Control Center. This information will be provided to the Benton and Franki in Counties EOC via the Unified Dose Assessment Center.

- Recovery Period

RL will provide assistance during post-accident periods to minimize radiation health hazards and decontamination problems to the State's Washington Fixed Nuclear Facility Reentry and Recovery Task Force, of which the counties are a member.

- Training and Exercises

$R L$ and the Counties should conduct an annual emergency response exercise designed to assess emergency response capabilities and provide needed training. Cooperative arrangements for such exercises and training will be agreed to in advance.

- Public Affairs

At the request of the Counties, RL will assist the Counties in the development of educational materials concerning radiation and its hazards and information regarding appropriate actions to be taken by the general public in the event of an accident involving radioactive materials.

- Warning to the Public

The Counties, with support from RL, will implement protective measures for the plume pathway zone(s) around the Hanford Site.

- Emergency Public Information

During an emergency, preliminary media releases from $\mathrm{RL}$, and from the Counties will be coordinated. For a Site Area or General Emergency, RL and Counties spokespersons will jointly prepare and release information statements from the Joint Information Center. 


\section{TERMS OF AGREEMENT}

This agreement will become effective upon signature and continue until canceled by either party by written notice to the other. Amendments or modification to this Agreement may be made upon uritten agreement by both parties to the Agreement.

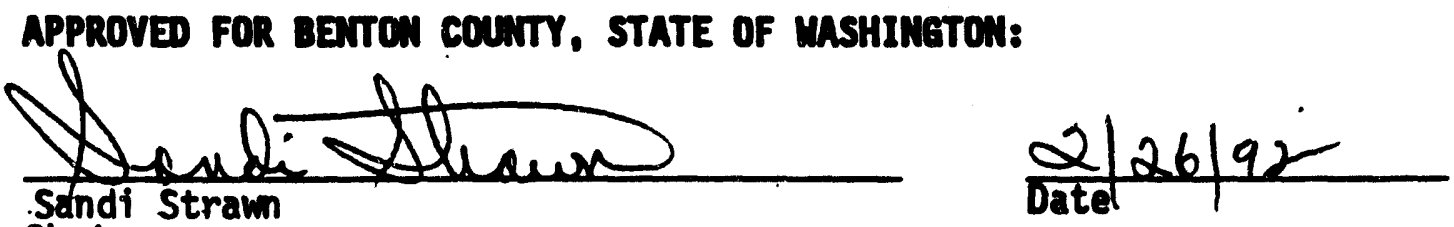

Chairman,

Benton County Emergency Management Council

Datel 26992

APPROVED AS TO FORH:

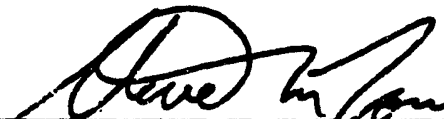

Deputy/Prosecuting Attorney

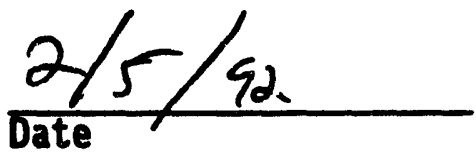

7 20n $221 \%$

Deputy Prosecuting Attorney

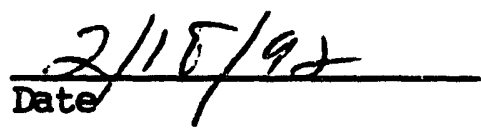

APPROY

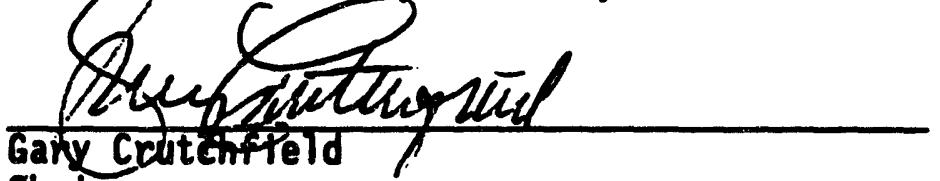

Chairman,

Frankl in County Emergency Management Board

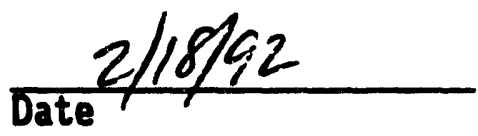

APPROVED FOR DOE RICHLAND FIELD OFFICE

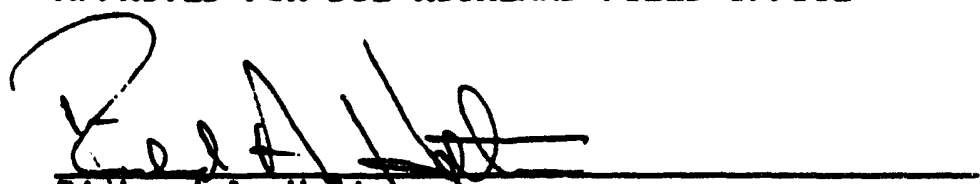

Richard A. Holten

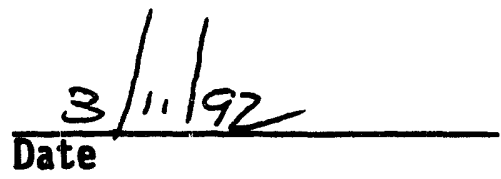

Director

Technical Support Division 


\section{DOE/RL-94-02, Rev. 0 \\ Department of Energy \\ Richland Operations Office \\ P.O. Box 550 \\ Richland, Washington 99352}

OCT 231991

Mr. Don Goodwin, Chairman

Board of County Commissioners

Grant County Courthouse

Ephrata, Washington 98823

Dear Mr. Goodwin:

\section{RADIOLOGICAL EMERGENCY PLANNING AND RESPONSE}

The purpose of this letter is to update our framework of cooperation between the DOE Field Office, Richland (RL), and Grant County, in the planning for and response to emergencies at the Hanford Site which might have consequences in Grant County.

RL is responsible for responding to all emergencies contained within the federally operated facilities located within the Hanford Site boundary. In the event that a Hanford emergency has offsite public health implications, RL and Grant County will coordinate implementation of their emergency plans.

RL will provide support and assistance to Grant County in the preparation and implementation of emergency response affecting Grant county by coordinating the activities of federal agencies which are parties to the Federal Radiological Monitoring and Assessment Program; assisting in radiological monitoring and decontamination, radiation exposure evaluation, and radiation health hazards assessment; providing medical advice on emergency treatment of persons exposed to radiation and technical advise on radioactive contamination, including protective action recommendations; and coordinating with your Department of Emergency Services in the development of plans for coping with radiological incidents occurring on the Hanford Site.

Operational emergencies may involve such things as reactor and non-reactor facilities, and safeguards and security matters.

Three classes of operational emergencies will be utilized; Alert, Site Area Emergency, and General Emergency. The descriptions of these classifications, along with the expected response actions of $\mathrm{RL}$ relative to each classification, are as follows:

1. Alert: An Alert represents events in progress or having occurred which involve an actual or potential substantial reduction of the level of facility safety and protection. Any environmental release of hazardous materials are expected to be limited to small fractions of the appropriate Protective Action Guideline (PAG) or Emergency Response Planning Guideline (ERPG) onsite. 
RL will:

- Promptly inform Grant County of the Alert status and of the reason for this classification.

- Activate its Emergency Control Center and Joint Information Center.

- Dispatch onsite monitoring teams.

- Provide status updates to Grant County at periodic intervals.

- Provide periodic meteorological assessments to Grant County, and if any releases are occurring, dose estimates for actual releases.

- Activate the Unified Dose Assessment Center, perform offsite monitoring and evaluation, and provide information to Grant County until the State of Washington monitoring team is activated, operating, and assumes responsibility.

- Close out by verbal summary within eight hours after conclusion of the event or by escalation to a more severe classification.

2. Site Area Emergency: A Site Area Emergency represents events which are in progress or have occurred involving actual or likely major failure(s) of facility safety or safeguards systems needed for the protection of onsite personnel, the public health and safety, the environment, or national security. Any environmental releases of hazardous materials are not expected to exceed the appropriate PAGs or ERPGs offsite.

3. General Emergency: General Emergency represents events which are in progress or have occurred that involve actual or imminent catastrophic failure of facility safety systems with potential for loss of confinement integrity, catastrophic degradation of facility protection systems, or catastrophic failure in safety or protection systems threatening the integrity of a weapon or test device which could lead to substantial offsite impacts. Any environmental release of hazardous materials can reasonably be expected to exceed the appropriate PAGs or ERPGs offsite.

For both a Site Area or. General Emergency, RL will:

- Promptly inform Grant County of the emergency classification and of the reason for this classification.

- Activate its Emergency Control Center and Joint Information Center.

- Dispatch onsite monitoring teams.

- Provide status updates to Grant County at periodic intervals.

- Provide periodic press briefings. 
DOE/RL 4-02, ROV. 0

Don Goodwin

- If protective action recommendations would have any envisioned impact upon Grant County, provide technical and managerial consultation on this envisioned impact to Grant County.

- Provide meteorological and dose estimates to Grant County as required.

- Close out by verbal summary within eight hours after conclusion of event, or, if a Site Area Emergency, by escalation to a General Emergency.

If these arrangements meet with your approval, please sign and return one copy of this letter.

We look forward to our continued good working relationships with your Department of Emergency Services.

$$
\text { Sincerely, }
$$

TSD:JLT

APPROVED:

Don Goodwin, Chairman

Board of County Commissioners

Grant County

DATE:
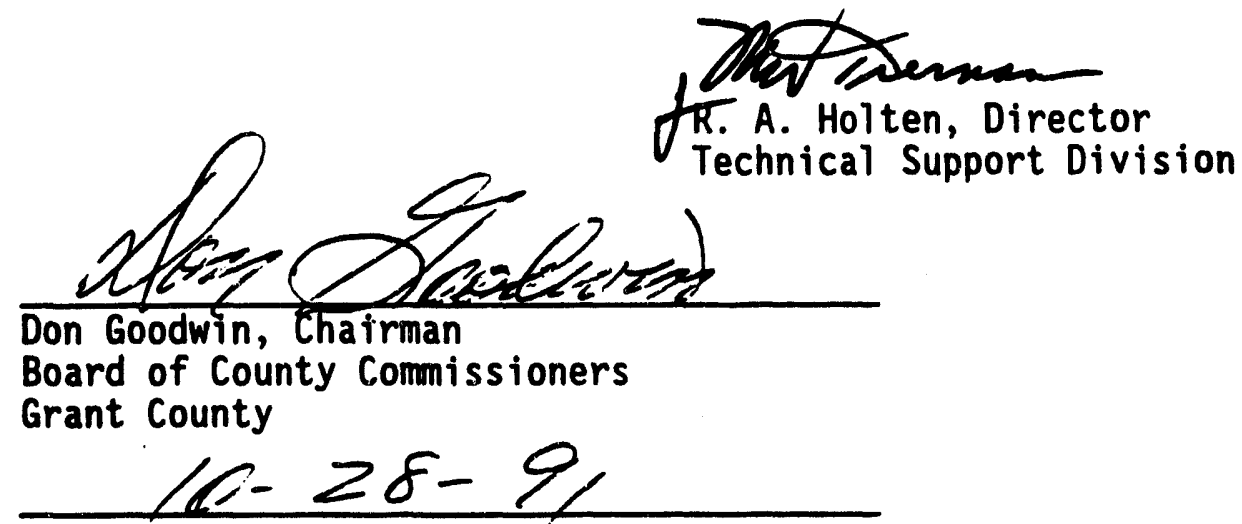
OCT 231991

Mr. Donald E. Larson

Washington Public Power Supply System

MD 1020

3000 George Washington Way

Richland, Washington 99352

Dear Mr. Larson:

MEMORANDUM OF UNDERSTANDING (MOU)

The attached MOU between DOE Field Office, Richland, (RL), and Washington Public Power Supply System (Supply System), signed in March 1991, establishes the framework for mutual support in the uni ikely event of an emergency affecting facilities at Hanford.

We are conducting a periodic review of such agreements. Please review this document. If you have any comments or questions, please contact Ms. Judy Tokarz, Emergency Management Coordinator, at 376-4766.

If the document remains satisfactory as written, please indicate by signing in the space provided and return the original to us. If we have not received comments or a signed concurrence within 30 days from the date of this letter, we will assume the MOU remains acceptable.

Thank you for your continued assistance.

Sincerely,

TSD:JLT

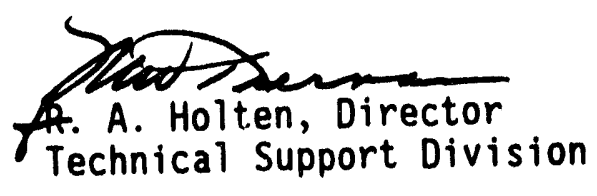

Attachment

Concurrence: I agree this MOU remains agceptable.

Signature:

D. E. Larson

Name:

Manager, Emergency Planning

Title:

Date:

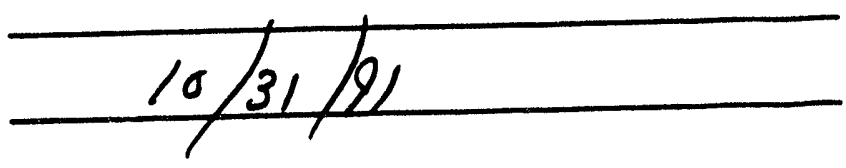


DOE/RL-94-02, ReV. 0

MEMORANDUM OF UNDERSTANDING

BETWEEN

WASHINGTON PUBLIC POWER SUPPLY SYSTEM

AND

DEPARTMENT OF ENERGY

RICHLAND OPERATIONS OFFICE

EMERGENCY PREPAREDNESS AND RESPONSE

I. BACKGROUND AND PURPOSE

This memorandum of understanding reaffirms the established framework of cooperation between the Washington Public Power Supply System (Supply System) and the Department of Energy, Richland Operatlons Offlce (RL), In the planning for and response to emergencles at the Hanford Site.

\section{RESPONSIBILITIES}

RL is responsible for direction and overview for all emergency response actions required within the Hanford Site, excluding the nonfederally operated facllitles. RL Wlll provide required assistance to the Supply System from the Supply System site boundary to the Hanford site boundary.

\section{AREAS OF COOPERATION}

Notification - Both parties are responsible for providing prompt notiflcation to the other in the event of an emergency impacting the other's facllities or operations.

Because of the proximity of the Fast Flux Test Faclilty, and assoclated faclilties in the 400 area. speclal arrangements concerning notification are established. This notification wlll be necessary in the event of a potentlal event which could affect the other facllity and should Include recommendations for protective measures. Each faclilty shall maintain provisions in their respective emergency procedures to ensure direct and timely notification of the adjacent facllity.

Access Control - RL will provide access control to the Hanford site in the event of a major emergency at the Supply System. Access control will be initlated through notification to the Hanford Patrol Operations Center (POC) or through the RL lialson representative in the Supply System' Securlty Decision Center. 
Communications Equipment - The Supply system will use existing RL communications systems through the POC contact for emergency communications between the Supply system and RL. The Supply System will continue to provlde emergency communications capablilty in the form of shortwave radlo and telephone llinks between the POC, county offices, and Supply System facllities for coordination of emergency response activitles outside of the Supply System site. Use of the POC contact by the Supply System will be IImited to activities assoclated with emergency preparedness.

The Supply System has Installed and will coritinue to maintaln a tone-controlled transcelver in the POC at no expense to the U.S. Government, to be operated on the same frequency as the other radios designated for the Supply System emergency system. This radlo can be utllized by $e$ ther party for notification purposes. RL, through the POC. wlll particlpate in perlodic testing, as necessary, to assure operation of the transcelver and meet any regulatory requirements for this function.

Emergency Decontamination Center - The Supply System will continue to include the Emergency Decontamination Center (EDC) as a resource for its emergency planning effort. RL will be reimbursed on a full cost recovery basis for use of the EDC.

Emergency Facllities and Equipment - Mutual assistance, as needed and avallable, will be provlded in the use of facllities and equipment for personnel decontamination. first ald, evacuation reassembly areas. resplratory protective equipment, protective clothing, vehicles, including buses and ambulances, survey instruments, and resources for river evacuation.

Radiation Control and Meteorology Data - Environmental and meteorology data, and radiological release evaluation data will be exchanged. Fleld monitoring teams and dose assessment assistance will be provided as needed. If the emergency is in an $\mathrm{RL}$ faclilty or outside the Supply system fence boundary, RL wlll have prlmary dose assessment and assoclated protective measure responsibllity. If the emergency originates at the Supply System. the Supply System will have primary responsibllity for the dose asesssment and assoclated protective measure responslbllities. Due to RL's unlque ownership of Hanford facllitles and propertles, RL shall particlpate along with the Supply System and the State of Washington in the development of joint dose assessment and protectlve action recomnendations in the Supply System's Meterology and Unifled Dose Assessment Center.

RL Wlll provide radlological assistance to the Supply system in accordance with the Federal Radlological Monitoring and Assessment Response Plan.

Training and Exerclses - Cooperatlve arrangements for exercises and training wlll be agreed to in advance. 
Public Information - In cooperation with the Countles. RL and the Supply System will jolntly assist the Countles in the development of educational materlals concerning radlation and Its hazards and information regarding approprlate actlons to be taken by the general publle in the event of an accldent involving radloactlve materlals.

Emergency Public Information - If the emergency origlnates on the llanford Site, outside the Supply System site boundary, RL wlll have primary emergency public information respons.lbllity. If the emergency orlginates at the Supply System, the Supply System wlll have the primary emergency public information responsibllity. Due to $\mathrm{RL}$ 's 'unlque ownership of Hanford facllitles and propertles. RL shall partlclpate as a partner with the Supply System In the Supply System's Jolnt Information Center.

\section{IERMS OF AGREEMENT}

The specific areas of assistance, as defined above, will be provided based upon avallabllity, and are limited to those emergency actions necessary to protect onsite personnel, the public health and safety and the environment in the event of a major emergency at the Hanford Site.

This memorandum of understanding w/ll become effective upon signature and continue until cancelled by elther of the partles by written notice to the other party. Amendments or modificatlons shall be in writing and slgned by both partles of the agreement.

APPROVED FOR THE DEPARTMENT OF ENERGY RICHLAND OPERATIONS OFFICE:
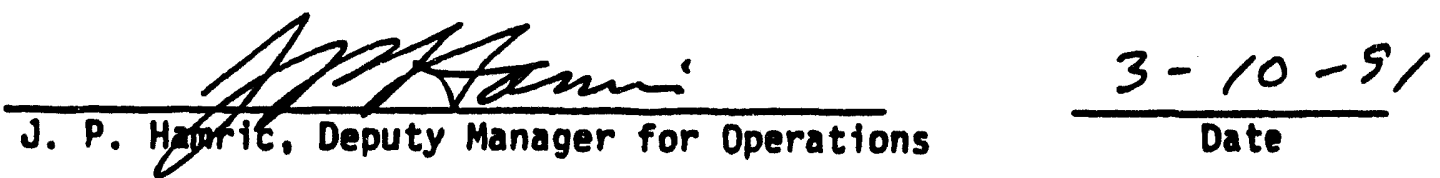

APPROVED FOR THE WASHINGTON PUBLIC POWER SUPPLY SYSTEM:

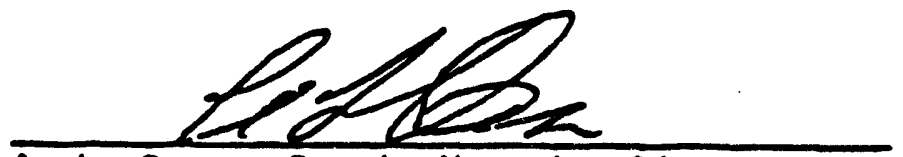

A. L. Oxsen, Deputy Managing Olrector

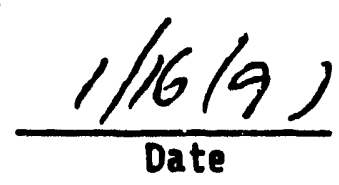


DOE/RL-94-02, Rev. 0

Department of Energy

Richland Operations Office

P.O. Box 550

Richland, Washington 99352

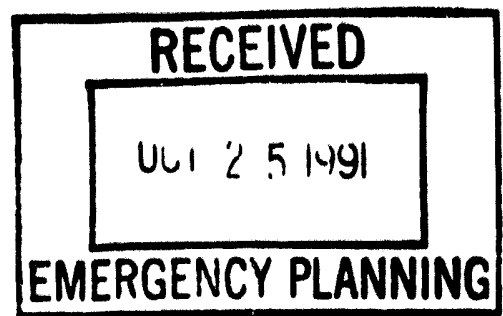

\section{OCT 231991}

:Mr. Donald E. Larson

Washington Public Power Supply System

MD 1020

3000 George Washington Way

Richland, Washington 99352

Dear Mr. Larson:

MEMORANDUM OF UNDERSTANDING (MOU)

The attached MOU between DOE Field Office, Richland (RL), Hanford

Environmental Health Foundation (HEHF) and Washington Public Power Supply

System (Supply System), signed in February 1989, establishes the framework for

treatment of a contaminated and injured person at the Emergency

Decontamination Facility (EDF) at the request of the Supply System.

We are conducting a periodic review of such agreements. Please review this document. If you have any questions or comments please contact

Ms. Judy Tokarz, Emergency Management Coordinator, at 376-4766.

If the document remains satisfactory as written, please indicate by signing in the space provided and return the original to us. If we have not received comments or a signed concurrence within 30 days from the date of this letter, we will assume the MOU remains acceptable.

Thank you for your continued assistance.

\section{Sincerely,}

TSD:JLT

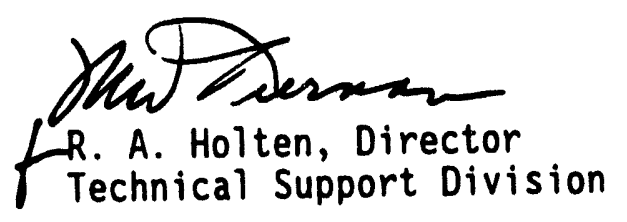

Attachment

Concurrence: I agree this morkemains fcceptable.

Signature:

D. E.

Name:

Manager. Emergency Planning

Title:

Date:

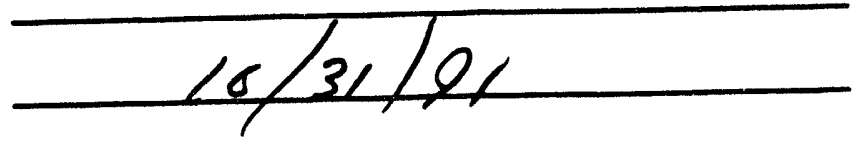


DOE/RL-94-02, Rev. 0

MEMORANDUM OF UNDERSTANDING BETWEEN

U. S. DEPARTMENT OF ENERGY, RICHLAND OPERATIONS OFFICE

HANFORD ENVIRONMENTAL HEALTH FOUNDATION, AND

WASHINGTON PUBLIC POWER SUPPLY SYSTEM

FOR

EMERGENCY RESPONSE AT THE HANFORD SITE

USE OF THE EMERGENCY DECONTAMINATION FACILITY

The Washington Public Power Supply System (Supply System), the U.S. Department of Energy, Richland Operations Office (DOE-RL) and the Hanford Environmental Health Foundation (HEHF) agree to the following procedures and responsibilities in connection with the Emergency Decontamination Facility (EDF) at Richland, Washington when that facility is used in response to emergencies at the Hanford site. These arrangements will be followed when implementing the applicable portions of Section III of the Memorandum of Understanding between the Supply System and the U.S. Department of Energy regarding Emergency Preparedness and Response which was executed in December 1982.

If the Supply System requests assistance from DOE-RL for treatment of a significantly contaminated and injured person:

- The Supply System will notify the HEHF physictan on call about the person who requires medical care. The Supply System will also notify the DOE-RL Patrol Operations Center (POC) who in turn will notify the DOE-RL Duty Officer and the Hanford Exposure Evaluator. The HEHF physician on call will respond to assess the injury and will coordinate care at the Emergency Decontamination Facility (EDF) and/or Kadlec Medical Center.

- The HEHF physician will direct activation of the EDF, when indicated, and will utilize personnel from HEHF, Kadlec Medical Center or other organizations as deemed appropriate.

o The Supply System will provide qualified health physics personnel and appropriate radiation protection instrumentation for responding to the emergency decontamination facility. Transportation of radiation protection personnel will normaily be provided by the Supply System unless agreed upon by the ambulance crew. Once the patient is delivered, the HEHF physician may elect to utilize other selected personnel for contamination and dose assessment, and can release the. Supply System health personnel to return to the plant. However, the Supply system remains responsible for dose assessment of Supply System personnel and its contractors and may provide a representative in the EDF for close evaluation. The Supply System will be responsible for all decontamination.

o Any requests for press releases will be directed to the Supply System. 
As preparation for an emergency covered under this agreement, the Supply System w111:

- Make available basic radiological safety training to HEHF and Kadlec Medical Center personnel on, at least, an annual basis.

- Maintain agreements with other hospitals to handle incidents involving multiple injuries to allow for overflow emergency cases from the Hanford Site to be handled elsewhere.

In return, HEHF wi11:

- Be avallable to participate in an annual drill involving a simulated contaminated patient.

- Coordinate activities relating to this agieement with Kadlec Medical Center including provisions for recelving critical patients or overflow of patients into the Kadlec Medical Center.

This agreement will become effective upon signature and will continue until cancelied by one or more of the parties by written notice to the other $(s)$.

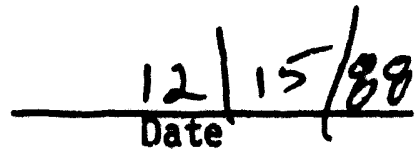

$\frac{2-21-89}{\text { Date }}$

$\frac{2 \text { Feb } 89}{\text { Date }}$

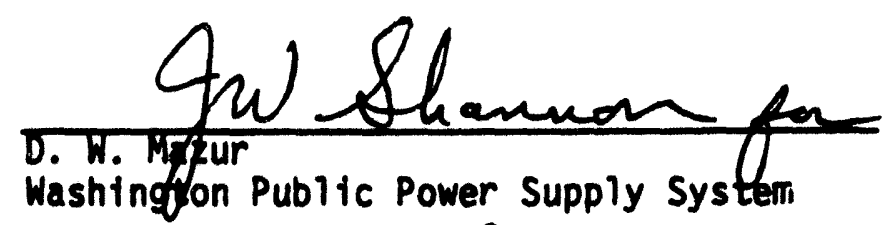

Washinguon Public Power Supply System

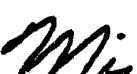

H. J. Lawrence

Richland Operations Office

United States Department of Energy

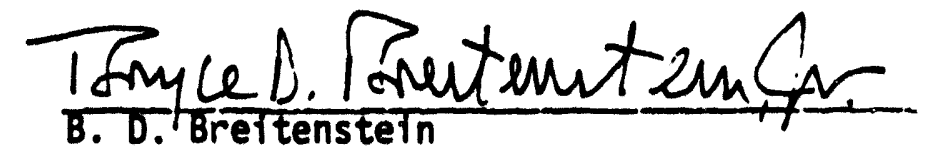

Hanford Environmental Health Foundation

WNP-1/2 Emergency Preparedness Plan

Appendix 4.5

Contract No. C-30042 
DOE/RL-94-02, Röv. 0

Memorandum of Understanding

between

Department of Enorgy

Fichland Fleld Office

and

Hanford Environmental Health Foundation

and

Slemens Nuclear Power Corporation

For the Use of the Emergency Decontamination Facillty

December 1991

Slemens Nuclear Power Corporation (SNP), the Department of Energy, Richland Field Office (DOE-RL) and the Hanford Environmental Health Foundation (HEHF) agree to the following procedures and responsibilities in connection with the Emergency Decontamination Facility (EDF) at Richland, Washington when that facility is used in response to emergencies at the SNP Plant Site.

If SNP requests assistance from DOE-RL for treatment of a significantly contaminated and injured person:

- SNP will notify the HEHF physician on call about the person who requires medical care. SNP will also notify the DOE-RL Patrol Operations Center (373-3800) who in turn will notfly DOE-RL Duty Officer and the Hanford Exposure Evaluator. The HEHF physician on call will respond to assess the injury, and will coordinate care at the Emergency Decontamination Facility (EDF) and/or Kadlec Medical Center.

- The HEHF physician will direct activation of the EDF, when indicated, and will utilize personnel from HEHF, Kadlec Medical Center or other organizations as deemed appropriate.

- SNP will provide radiation monitoring personnel and appropriate radiation protection instrumentation with the ambulance or have personnel meet the ambulance at the receiving area. Once the patient is delivered, the HEHF physician may elect to utilize other selected personnel for contamination and dose assessment, and can release the SNP radiation monitoring personnel to return to the plant. However, SNP remains 
DOE/RL-94-02, Rev. 0

responsible for dose assessment of SNP personnel and may provide a representative in the EDF for close evaluation.

- SNP agrees to undertake all costs and expenses incurred that directly result from this agreement. DOE-RL will be reimbursed on a full cost recovery basis for use of the EDF.

- Any requests for press releases will be directed to SNP.

As preparation for an emergency covered under this agreement, SNP will:

- Make available, when requested, basic radiological safety training to HEHF and Kadlec Medical Center personnel on, at least, an annual basis.

In return, HEHF will:

- Be avallable to participate in periodic drills involving simulated contaminated patients.

- Coordinate activities relating to this agreement with Kadlec Medical Center including provisions for receiving critical patients or overflow of patients into the Kadlec Medical Center.

This agreement will become effective upon signature and will continue until canceled by one or more of the parties by written notice to the other(s).

Approved

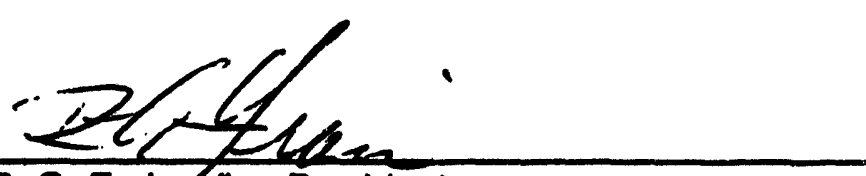

R. G. Frain, Vice President

Operations Division

Siemens Nuclear Power Corporation

J. D.Wagoner, Manager

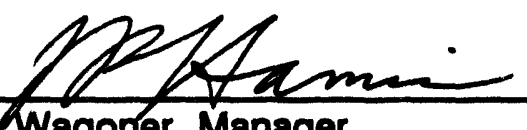

Richland Field Office

United States Department of Energy

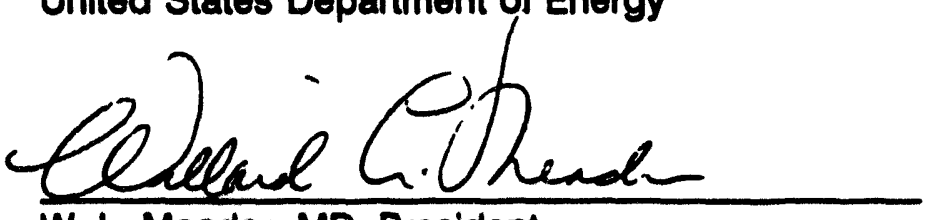

W. L. Meader, MD, President

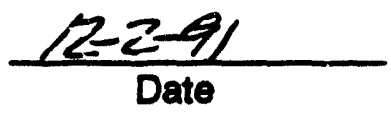

Hanford Environmental Health Foundation

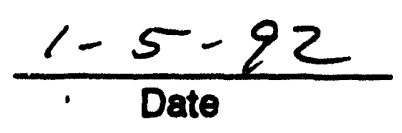




\section{(c)}

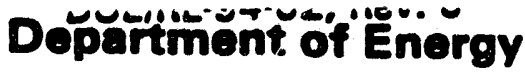

Richland Operations Office

P.O. Box 550

Richland, Washington 99352

\section{OCT 232991}

Mr. Robert' Richey, Chief

Meteorological Services Division

National Weather Service

Western Regional Headquarters

P.0. Box 11188, Federal Building

Salt Lake City, Utah 84147

Dear Mr. Richey:

\section{LETTER OF AGREEMENT}

This is an update to our letter of March 10, 1989, on the same topic. DOE Field office, Richland (RL), would like to renew the agreement with the National Weather Service (NWS), Washington area, for possible response to an emergency at the Hanford Site.

The following conditions would continue to be applicable to this agreement:

RL will provide to the NWS:

1. Notification of emergencies occurring on the Hanford Site upon activation of the RL Emergency Control Center.

2. Meteorological information including routine hourly surface observations and special observations via Automated Field Operation Services (AFOS). This information will be provided by the Hanford Meteorology Station operated by the Pacific Northwest Laboratory. In the event of emergencies on the Hanford Site, hourly observations will be supplemented with observations from the telemetry station on Rattlesnake Mountain (Station \#20) and from other reporting stations as necessary. These supplemental observations will consist of station number, wind speed, and wind direction. Wind speed and direction will be reported in accordance with Federal Meteorological Handbook No. 1 (Surface Observations). (Special observations may be omitted when the forecaster's workload is such that other duties take precedence.)

The NWS will provide to RL:

1. Organizational structure, personnel 1ists, 24-hour telephone numbers, locations, and areas of responsibility of NWS offices that may be involved with incidents or emergencies on the Hanford Site.

2. Synoptic scale weather information and forecasts in support of activities to mitigate unusual events, incidents, or emergencies on the Hanford Site. 
This agreement may be terminated by either party upon 30 days written notice to the other party. If these arrangements meet with your approval, please sign below and return one copy of this letter. If you have any questions, please contact Ms. Judy Tokarz, Emergency Management Coordinator, at (509) 376-4766.

$$
\text { Sincerely, }
$$

TSD:JLT

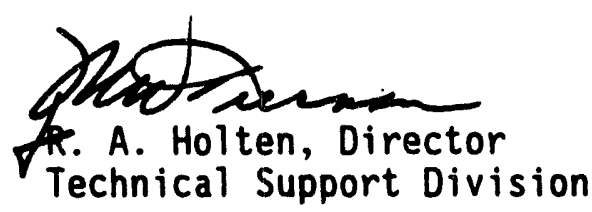

APPROVED:

SIGNATURE: Olusertychen D. Lhei

NAME:

Christopher D. H111

TITLE:

Meteorologist-In-Charge/Area Manager

DATE:

December 10, 1991 
DOE/RL-94-02, Rov. 0

Department of Energy

Richland Operations Office

P.O. Box 550

Richland, Washington 99352

\section{OCT 2 з 1991}

\section{RECEIVED}

\author{
OCT 251991
}

UUN LAÜ Ö LUUNUES

ADMINIS

Mr. T. F. Corley, Administrator

Our Lady of Lourdes Hospital

520 North 4th

Pasco, Washington 99301

Dear Mr. Corley:

\section{LETTER OF AGREEMENT}

This is an update to our letter of February 24, 1989, on the same topic. DOE Field Office, Richland (RL), would like to renew the agreement with our Lady of Lourdes Hospital. This agreement provides assurance that in the event of a major radiation accident involving personnel of $\mathrm{RL}$, or its contractors or subcontractors, affected persons will be admitted to your facility for appropriate medical care.

The following conditions will continue to be applicable to this agreement:

1. RL will provide health physics services and available supporting assistance as requested by Our Lady of Lourdes. These services will be limited to activities performed at the hospital.

2. The responsibilities of Our Lady of Lourdes will be 1 imited to activities performed at the hospital.

3. Our Lady of Lourdes has the right to limit admission of such patients to those numbers as can be properly handled.

4. Our Lady of Lourdes would serve as one of the backup facilities to the RL Emergency Decontamination Facility in Richland.

5. These arrangements may be terminated by Our Lady of Lourdes or by $\mathrm{RL}$ upon written notice to the other, which notice shall not become effective for at least 30 days after the date thereof. 
If these arrangements meet with your approval, please sign below and return one copy of this letter. If you have any questions regarding this agreement, please contact Ms. Judy Tokarz, Emergency Management Coordinator, on 376-4766.

Sincerely,

TSD:JLT

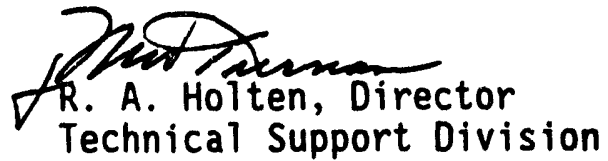

APPROVED:

SIGNATURE :

NAME:

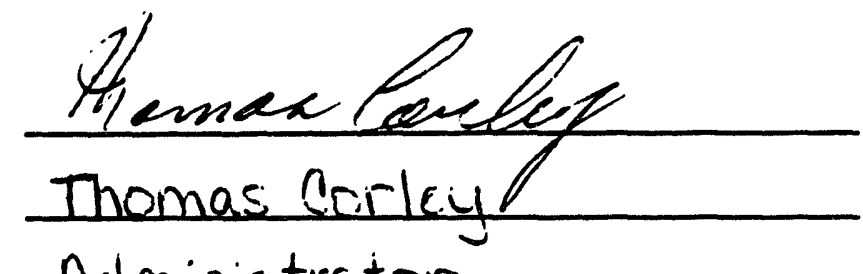

TITLE:

Administrator

DATE :

11/1/5i


Richland Operations Office

P.O. Box 550

Richland, Washington 99352

\section{OCT 231991}

Mr. Jon Davis, Administrator

Kadlec Hospital

888 Swift boulevard

Richland, Washington 99352

Dear Mr. Davis:

\section{LETTER OF AGREEMENT}

This is an update to our letter of February 24, 1989, on the same topic. DOE Field office, Richland (RL), would like to renew the agreement with Kadlec Hospital. This agreement provides assurance that in the event of a major radiation accident involving personnel of $\mathrm{RL}$, or its contractors or subcontractors, affected persons will be admitted to your facility for appropriate medical care.

The following conditions will continue to be applicable to this agreement:

1. Patients will be admitted by a physician who has staff privileges at Kadlec Hospital.

2. RL will provide health physics services and available supporting assistance as requested by Kadlec Hospital. These services and support will be limited to activities performed at the hospital.

3. The responsibilities of Kadlec Hospital will be limited to activities performed at the hospital and at the Emergency Decontamination Facility (EDF).

4. Kadlec Hospital has the right to limit admission of such patients to those numbers as can be properly handled.

5. These arrangements may be terminated by Kadlec Hospital or by RL upon written notice to the other, which notice shall not become effective for at least 30 days after the date thereof. 
DOE/RL-94-02, Rov. 0

Jon Davis

-2 -

CCT 231991

If these arrangements meet with your approval, please sign below and return one copy of this letter. If you have any questions regarding this agreement, please contact Ms. Judy Tokarz, Emergency Management Coordinator, on 376-4766.

Sincerely,

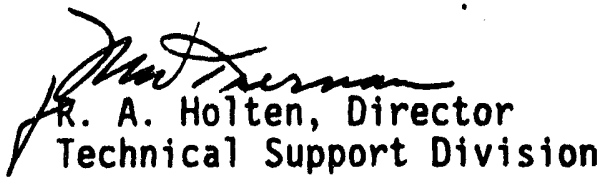

APPROVED:

SIGNATURE:

NAME :

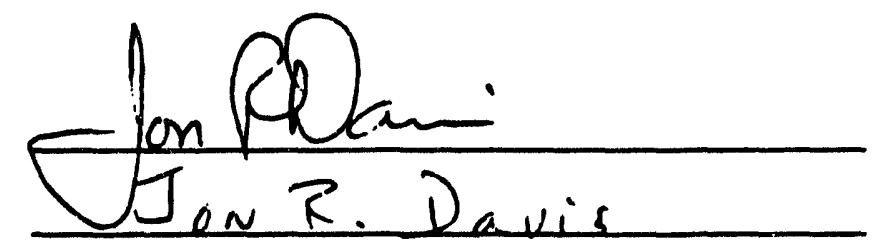

TITLE:

Administratar

DATE:

11) $8 / 91$ 


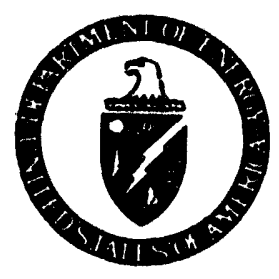

\section{DOE/RL-94-02, Rov. 0 Department of Energy}

Richland Operations Office P.O. Box 550

Richland, Washington 99352

\section{OCT 231991}

Mr. Michael R. Fraser, Administrator

Kennewick General Hospital

900 South Auburn

Kennewick, Washington 99336

Dear Mr. Fraser:

\section{LETTER OF AGREEMENT}

This is an update to our letter of February 24, 1989, on the same topic. DOE Field Office, Richland (RL), would like to renew the agreement with Kennewick General Hospital. This agreement provides assurance that in the event of a major radiation accident involving personnel of $\mathrm{RL}$, or its contractors or subcontractors, affected persons will be admitted to your facility for appropriate medical care.

The following conditions will continue to be applicable to this agreement:

1. RL will provide health physics services and available supporting assistance as requested by Kennewick General Hospital. These services and support will be limited to activities performed at the hospital.

2. The responsibilities of Kennewick General Hospital will be limited to activities performed at the hospital.

3. Kennewick General Hospital has the right to limit admission of such patients to those numbers as can be properly handled.

4. Kennewick General Hospital would serve as one of the backup facilities to the RL Emergency Decontamination Facility in Richland.

5. These arrangements may be terminated by Kennewick General Hospital or by $\mathrm{RL}$ upon written notice to the other, which notice shall not become effective for at least 30 days after the date thereof. 
If these arrangements meet with your approval, please sign below and return one copy of this ietter. If you have any questions regarding this agreement, please contact Ms. Judy Tokarz, Emergency Management Coordinator, on 376-4766.

$$
\text { Sincerely, }
$$

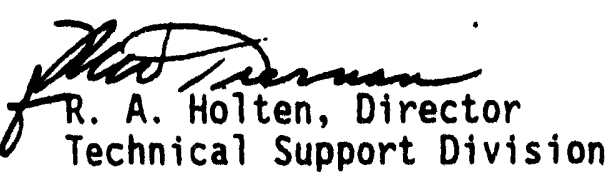

TSD:JLT

APPROVED:

SIGNATURE:

NAME:

TITLE:

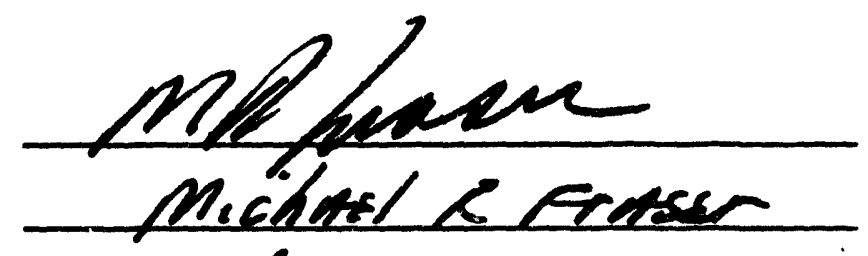

DATE:

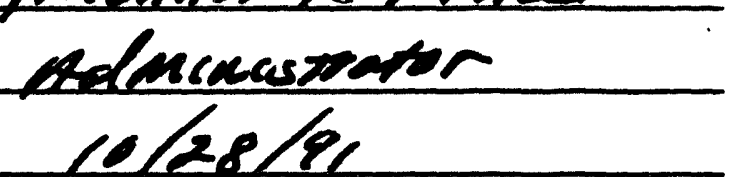




\section{MEMORANDUM OF UNDERSTANDING}

\section{BETUEEN}

THE U.S. DEPARTMENT OF ENERGY, RICHLAND FIELD OFFICE

THE WASHINGTON PUBLIC POWER SUPPLY SYSTEN

BENTON COUNTY, WASHINGTON

FRANKLIN COUNTY, WASHINGTON

Nid

THE :THIRTEENTH COAST GUARD DISTRICT

\section{PURPOSE}

The purpose of this Memorandum of Understanding (MOU) is to ensure safety on the Columbia River during an emergency at the Hanford Site through enhanced coordination and cooperation among the following signatory parties:

- The U.S. Department of Energy, Richland Field Office (RL)

- The Washington Public Power Supply System (Supply System)

- Benton County, Washington (Benton County)

- Franklin County, Washington (Frankl in County)

- The Thirteenth Coast Guard District (Coast Guard)

\section{BACKGROUND}

A. The Hanford Site is an area of approximately 560 square miles located in South Central Washington which is used for a number of nuclear and chemical activities. The Site encompasses the Columbia River from river mile 342 to river mile 392. The area is managed by RL and includes facilities operated by RL contractors, and the WNP-2 power reactor, which is owned and operated by the Supply System on land leased by the United States to the Supply System. These facilities may have the potential for adversely impacting public safety in the event of an emergency.

B. In recognition of the hazards associated with a hazardous materials (radiological and/or non-radiological) incident, both RL and the Supply System have developed comprehensive emergency plans to deal with the wide range of possible impacts. Where those impacts extend to the Columbia River and enter into the jurisdictions of other agencies, it is vitally important that all of the involved agencies and organizations understand each other's responsibilities and capabilities and that an effective plan to minimize the impacts be established. 
C. In compliance with federal guidelines, RL, Supply System, and Benton and Franklin Counties have developed procedures to ensure that people on or along the Columbia River can be alerted to evacuate the river. Beyond meeting the requirements, RL and the Supply System agree to support a County request for additional notification to boaters, through river sweeps using emergency response boats, providing that the safety of boat crews will not be jeopardized.

III. SCOPE

This MOU:

A. Outlines the responsibilities of the involved parties.

B. Defines actions to be taken by each party in response to an incident.

C. Promotes the best use of personnel and equipment through cooperative effort.

D. Provides for timely exchange of information among the parties to permit proper planning, execution and evaluation.

\section{RESPONSIBILITIES}

A. The U. S. Coast Guard, through the Thirteenth District Commander in Seattie, Washington, and the Captain of the Port in Portland, Oregon, may regulate activities on navigable waters within the Hanford Site when necessary to prevent harm to persons, property and the environment in or on those waters.

B. RL is responsible for coordinating actions and responding to all emergencies contained within the federally operated facilities located within the Hanford Site boundaries.

C. The Supply System is responsible for coordinating actions and responding to all emergencies generated within its facilities.

D. Benton and Franklin Counties are responsible for the safety of persons, property and the environment within their areas of jurisdiction but outside the Hanford Site.

\section{v. EMERGENCY CLASSIFICATIONS}

Emergency classifications will be used to describe hazardous materials emergencies occurring at the Hanford Site. For RL facilities, the emergency classifications will also be used for transportation and security emergencies. 
$-3-$

A. Unusual Event - (Supply System only) An event in progress or having occurred which indicates a potential reduction of the level of safety of the facility. Little or no potential for offsite release of hazardous material is expected.

B. Alert - An event in progress or having occurred which involves an actual or potential substantial degradation of the level of safety of the facility. Small releases of hazardous materlals may occur but would not require public protective actions.

C. Site Area Emergency - An event in progress or having occurred which involves actual or likely major fallures of facility functions needed for protection of workers and the public. A significant release of hazardous materials may occur which may warrant 1 imited, precautionary public protective actions.

D. General Emergency - An event in progress or having occurred which involves actual or imminent substantial reduction of facility safety systems. Large amounts of hazardous materials have or could be released requiring public protective actions.

VI. ACTIONS

A. RL:

1. Whenever it has an alert, site area or general emergency, RL will notify the Coast Guard Marine Safety Office, Portland.

2. Whenever the Supply System or RL has declared a site area or general emergency that could have impacts between White Bluffs Ferry Landing and Leslle Groves Park, RL will provide a manned boat with radiation monitoring support to establish the upriver boundary of the safety zone. Upon the request of Benton and Frankl in Counties, and if conditions permit, the RL boat will sweep the river to advise boaters to evacuate. RL will also dispatch personnel to White Bluffs Landing to provide assistance in conducting radiation surveys until the Washington State Field Teams arrive.

3. Whenever RL has declared a site area or general emergency that could have impacts between Vernita Bridge and White Bluffs Ferry Landing, RL will provide two manned boats with radiation monitoring support to sweep the river (conditions permitting) to advise boaters to evacuate the Columbia River, and establish the upriver and downriver boundary of the safety zone. RL will also dispatch personnel to White Bluffs and Vernita Bridge Landings to provide assistance in conducting radiation surveys until the Washington State Field Teams arrive. 
DOE/RL-94-02, Rov. 0

$-4-$

B. Supply System:

1. Whenever it has declared an alert, site area or general emergency, the Supply System will notify the Coast Guard Marine Safety Office, Portiand.

2. Whenever the Supply System or RL have declared a site area or general emergency that could have impacts between Leslie Groves Park and White Bluffs Ferry Landing, the Supply System will provide assistance in conducting radiation surveys at lesile Groves Park unt 11 the Washington State Field Teams arrive.

C. Coast Guard:

1. For all site area or general emergencies, the Coast Guard will establish a safety zone on the Columbla River based upon the recommendations of RL or the Supply System and will broadcast a river closure notice to mariners.

D. Benton County:

1. For all site area or general emergencies Benton County will broadcast appropriate evacuation notices over the emergency broadcast system.

2. Whenever the Supply System or RL have declared a site area or general emergency that could have impacts between Leslie Groves Park and White Bluffs Ferry Landing, Benton County wi11:

a. Activate sirens to alert boaters along the Columbia River.

b. The Benton County Sheriff will, if conditions permit, provide a manned boat to estabi ish the downriver boundary of the safety zone. Upon the request of Benton and Franklin Counties and if conditions permit, the Benton County Sheriff boat will sweep the river to advise boaters to evacuate.

E. Franklin County:

1. Whenever the Supply System or RL have declared a site area or general emergency that could have impacts between Leslie Groves Park and White Bluffs Ferry Landing, Frankl in County will, if conditions permit, provide a manned Sheriff's Boat, to perform RL or Benton County Sheriff boat functions in the event either of those craft are unavaliable to respond.

\section{PUBLIC EDUCATION}

Benton County Emergency Management and Frankl in County Office of Emergency Management will conduct a public education program to inform recreational users of the Columbia River of emergency procedures. 
DOE/RL-94-02, Rev. 0

$\cdot-5-$

VII. RESOURCES

Each agency is responsible for costs it incurs under the emergency response provisions of this MOU.

IX. RETEITION OF EXISTING AUTHORITY

Nothing in this MOU shall detract from the existing responsibilities or authorities of each party.

X. ADAINISTRATION

RL will provide secretarial support to administer this MOU.

XI. EFFECTIVE DATE, REVISIONS NDD TERMIMATION

A. The provistons of this MOU will become effective upon signature of all parties hereto. It will remain in effect until terminated by agreement of all parties. Any party may withdraw at any time provided 30 days written notice is given to all parties. Amendments may be made at any time subject to the concurrence of all parties.

B. Withdrawal of the Coast Guard without prior notice is understood in the event of:

1. declaration of National Emergency;

2. transfer of the Coast Guard to the Department of the Navy; or

3. activation of part or all of Maritime Defense Zone Pacific. 
DOE/RL-94-02, ROV. 0

$-6-$

APPROVED FOR THIRTEEITH COAST GUARD DISTRICT:

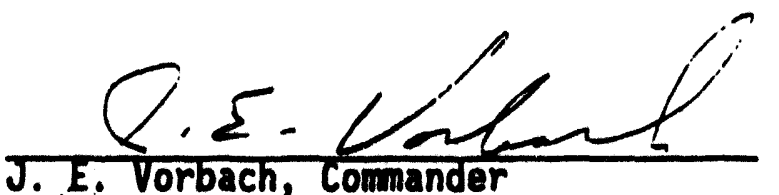

Thírteenth Coast Guard District

$$
\frac{3-22-93}{\text { Date }}
$$

APPROVED FOR MASHINETON PUBLIC PONER SUPPLY SYSTEN:

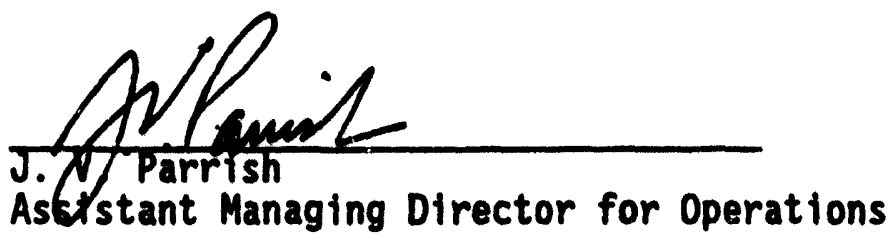

$\frac{7-13-93}{\text { Date }}$

APPROVED FOR DOE RICHLAD FIELD OFFICE:

$P 11010$

Richard Hot ten, oirector

Quality, Safety and Health Programs Division

$\frac{2-2-93}{\text { Date }}$

APPROVED FOR FRANKLIN COUNTY, STATE OF WASHINGTON:
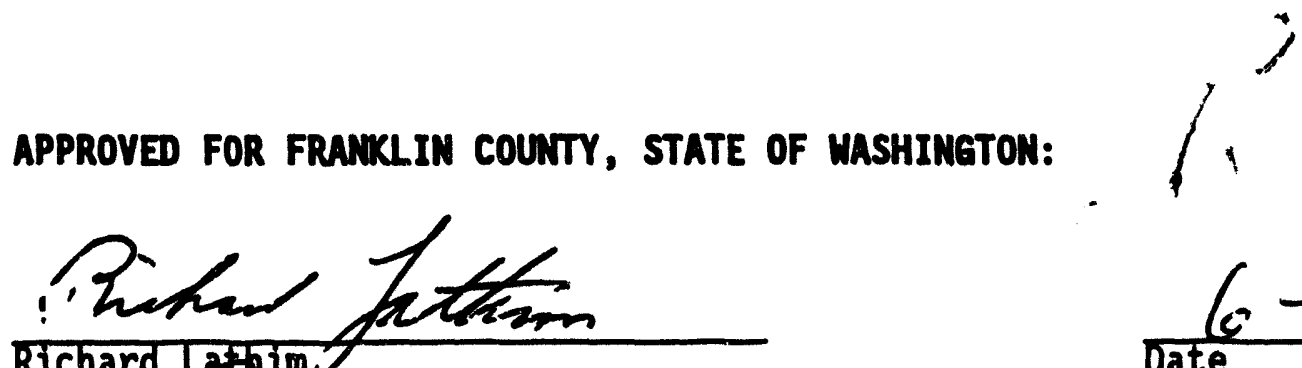

Richard

athim

Sheriff

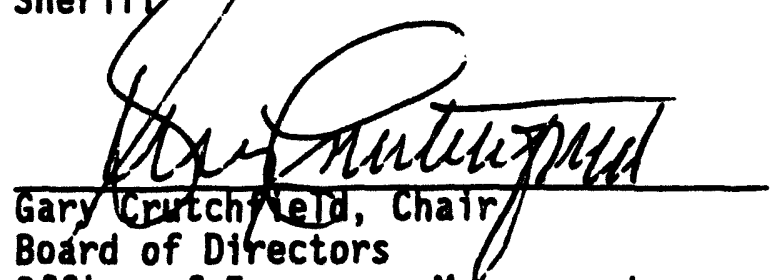

Office of Emergency Mahagement 
DOE/RL-94-02, Rov. 0

$-7-$

APPROVED FOR BENTON COUNTY, STATE OF WASHIMGTON:

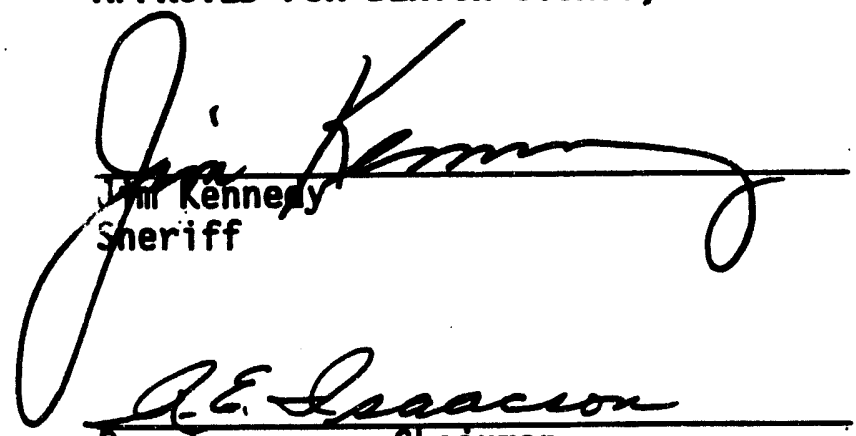

Ray Isaacson, Chaírman

Emergency Management Council

APPROY TOTS TO FORA:

Benton County Prosecutor

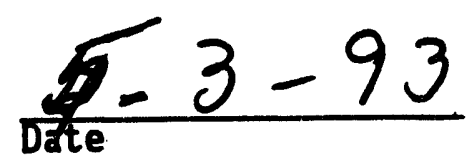

$\frac{4: 29-93}{\text { Date }}$

$\frac{4-29-93}{\text { Date }}$ 
DOE/RL-94-02, Rev. 0

MEMORANDUM 'OF UNDERSTANDING

\author{
Between the \\ DEPARTMENT OF ENERGY \\ RICHLAND OPERATIONS OFFICE
}

and the

STATE OF OREGON

This Memorandum of Understanding between the State of Oregon (hereafter "State") and the U.S. Department of Energy, Richland Operations Office (hereafter DOE-RL) expresses the desire of the parties to cooperate in matters of mutual interest; it sets forth mutually agreeable principles of cooperation between the State and DOE-RL in areas subject to the jurisdiction of the State or DOE-RL or both. This agreement is intended to provide the basis for exploration of subsequent detailed sub-agreements between the parties.

Close cooperation between the signatories will help assure that the goals and policies of State and Federal law will be carried out efficiently and expeditiousiy without diminishing the responsibilities or authorities of either party.

With the execution of this Memorandum, the State and DOE-RL agree to consult and cooperate in expioring and devising appropriate procedures to minimize duplication of effort to the extent permitted by State and Federal law, to avoid delays in decision-making and to ensure the exchange of information that is needed to make the most effective use of the resources of the State and DOE/RL in order to accomplish the purpose of both parties.

\title{
PRINCIPLES OF COOPERATION
}

1. The State and DOE-RL agree to explore together the development of detailed sub-agreements in areas of mutual concern.

2. Sub-agreements under this Memorandum may provide for activities to be performed by either party under mutually acceptable guidelines and criteria which assure that the needs of both are met. For activities performed by one party at the request of the other party under specific sub-agreements to this Memorandum, either party may explore means by which compensation can be made available to the other party or by which the costs may be shared by the parties.

3. Nothing in this Memorandum is intended to restrict or extend the constitutional or statutory authority of either DOE-RL or the State. 
DOE/RL-94-02, Rev. 0

$-2-$

4. The principal DOE-RL contact under this Memorandum shall be the Assistant Manager for Safety, Environment and Safeguards (AMS) or his or her designee. The principal State contact shall be the Director of the Oregon Department of Energy or his or her designee.

Sub-agreements will name appropriate individuals, agencies or offices as contacts.

5. This Memorandum shall take effect immediately upon signing by the Governor of the State of Oregon and the Manager. DOE-RL' and may be terminated upon 30 days written notice by either party.

APPROVED FOR STATE OF OREGON:

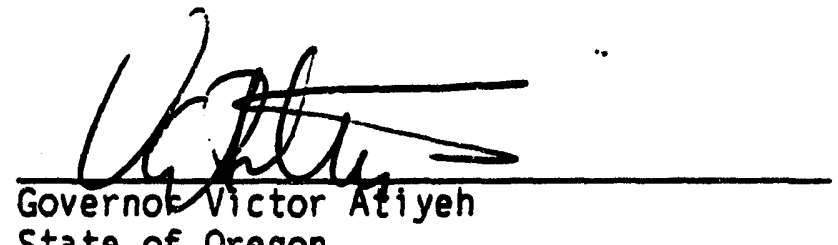

State of Oregon

APPROVED FOR THE DEPARTMENT OF ENERGY

RICHLANDS OPERATIONS OFFICE:

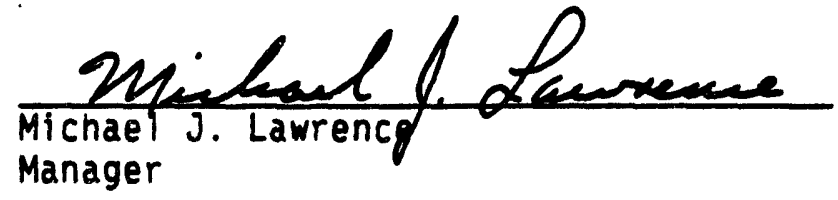

$\frac{11-10.86}{\text { Date }}$

$\frac{12-12-86}{\text { Date }}$ 
DOE/RL-94-02, Rev. 0

\author{
SUB-AGREEMENT I \\ BETWEEN \\ STATE OF OREGON \\ AND \\ DEPARTMENT OF ENERGY \\ RICHLAND OPERATIONS OFFICE \\ EMERGENCY PREPAREDNESS AND RESPONSE
}

I. BACKGROUND AND PURPOSE

This Memorandum of Understanding establishes a framework of cooperation between the State of Oregon (the State) and the Department of Energy. Richland Operations Office (DOE-RL), in the planning for and providing notification and interface in the event of an incident on the Hanford Site which might have offsite consequences, and coordinating Federal emergency radiological assistance, if required, in the event of an incident in the State of Oregon.

\title{
II. RESPONSIBILITIES
}

The Department of Energy's Richland Operations Office is responsible for responding to all emergencies contained within the federally operated facilities located within the Hanford Site boundaries. In the event that a Hanford emergency which might have offsite public health implications, DOE-RL and the State will coordinate implementation of their emergency plans.

The State of Oregon is responsible for responding to all emergencies within the State of Oregon with the exception of radioactive materials which pertain to the national security and are under the jurisdiction of the U.S. Department of Defense or the U.S. Department of Energy. In the event that resources are required beyond those avallable within the State, DOE-RL Will provide radiological support and assistance to the extent available and at the extent requested by the State as outlined in the Federal Radiological Monitoring and Assessment Response Plan (FRMAP).

DOE-RL will provide support and assistance to the state in preparation and implementation of emergency responses affecting the State of Oregon by:

A. Coordinating the activities of Federal agencies which are parties to the FRMAP.

B. Assisting in radiological monitoring and decontamination; radiation exposure evaluation and radiation health hazards assessment.

C. Providing medical advice on emergency treatment of persons exposed to radiation and technical advice on radioactive contamination. 
DOE/RL-94-02, Rev. 0

$-2-$

D. Cooperating in implementing and improving as necessary the State plan for emergencles occurring in the State of Oregon or on the Hanford Site.

E. Cooperating in the generation and release of public information.

The State of Oregon will provide support and assistance to DOE-RL in preparation and implementation of emergency responses affecting the State of Oregon by:

A. Coordinating radiological monitoring activities with DOE-RL, as appropriate.

B. Cooperating with appropriate DOE-RL officials in implementing and improving as necessary the FRMAP and the state plan for emergencies in the State of Oregon or on the Hanford site. This cooperation will be limited to those areas which are pertinent to the joint emergency response effort.

\section{III: EMERGENCY ACTION LEVELS AND RESPONSE ACTIONS}

Five classes of emergency action levels will be utilized. These classes are: (1) off normal event, (2) unusual event, (3) alert, (4) site area emergency, and (5) general emergency. The description of these classes and the response actions are as follows:

A. Off Normal Event

This class is described as a nonemergency event (at Hanford only) of general public interest.

DOE-RL will inform the Oregon Department of Energy $\left(O D O^{i}\right)$ of such events before the close of the next working day of the event or prior to its issuance of a news release, whichever comes first.

B. Unusual Event

This class is described as an event in progress or having occurred which normally would not constitute an emergency but which indicates little or no potential for offsite release of radioactive material. 
DOE/RL-94-02, Rev. 0

$-3-$

DOE-RL will inform the ODOE, or vice versa, of the nature of the unusual event, escalate to a more severe class, if appropriate, or close out with verbal summary within 24 hours. Notification of ODOE will be included in the initial notification of State, County and Federal agencies. ODOE will coordinate with DOE-RL in release of public information as necessary.

C. Alert

This class is described as an event in progress or having occurred which involves an actual or potential substantial reduction of the level of safety of the facility. Limited offsite releases of radioactive materials may occur.

DOE-RL will inform the ODOE, or vice versa, of the nature of the alert, escalate to a more severe class, close out or recommend reduction in emergency class as appropriate. Notification of ODOE will be included in the initial notification of State, County and Federal agencies. The State will begin a limited activation of the Emergency Operations Center to facilitate communications on technical information and to coordinate public information.

D. Site Area Emergency

This class is described as an event in progress or having occurred which involves actual or likely major fallures of facllity functions which are needed for the protection of onsite personnel, the public health and safety, and the environment. Offsite releases of radioactive materials are not occurring or likely to occur which would exceed levels requiring protective action recommendations or guidelines.

DOE-RL will inform the ODOE, or vice versa, of the nature of the Site area emergency, escalate to general emergency class, or close out or recommend reduction in emergency class as appropriate. Notification of ODOE will be included in the initial notification of State, County and Federal agencies. The State will activate the Emergency Operations Center and dispatch field teams to the vicinity of the Hanford area. Oregon's field teams will be prepared to assist DOE-RL upon request through ODOE. 
DOE/RL-94-02, Rev. 0

E. General Emergency

This class is described as an event in progress or having occurred which involves actual or imminent substantial reduction of facillty safety systems. Releases offsite of radioactive materials are occurring or expected to occur and exceed levels requiring protective action recommendations or guidelines.

DOE-RL w1ll inform the ODOE or vice versa, of the nature of the general emergency, recommend reduction of emergency class. or close out as appropriate. Notification of ODOE will be included in the initial notification of State, County and Federal agencies. The State will activate the Emergency Operations Center, dispatch field teams to the vicinity of the Hanford area, and may recommend public protective actions in the State of Oregon. Oregon's field teams will be prepared to assist DOE-RL upon request through ODOE.

\section{AREAS OF COOPERATION}

A. Notification

The ODOE will be the single point of contact for notification to the State regarding emergencies. Authentication of the notification call to the State will be effected by a return call to DOE-RL, if necessary.

The Oregon State Health Oivision or ODOE will notify DOE-RL if a Radiological Assistance Program (RAP) or Federal

Radiological Monitoring and Assistance Plan (FRMAP) response is requested. DOE-RL will only respond to an emergency in the State of Oregon at the request of the State.

B. Radiological Assessment and Evaluation

During a RAP or FRMAP response, DOE-RL will provide quality assured radiological technical data to the state. DOE-RL will provide protective action recommendations to the State if appropriate.

C. Intermediate and Recovery Period

DOE-RL will provide assistance to the state to minimize radiation health hazards and decontamination problems, until 
DOE/RL-94-02, Rev. 0

$-5-$

the Environmental Protection Agency assumes the lead agency in support of the State, as outlined in FRMAP. Any Federal agency or contractor assisting the State of Oregon in behalf of DOE-RL will do so in compllance with the agreements established in this Memorandum of Understanding.

D. Training and Exercises

DOE-RL and the State will particlpate in training and exercises at their own expense. Cooperative arrangements for emergency response exercises will be agreed to in advance and will be designed to assess emergency response capabilities and provide needed training.

v. AVAILABILITY OF FUNDING

Performance of US DOE's activities under this agreement is subject to the avallability of appropriated funds for such purpose.

VI. TERM OF AGREEMENT

This agreement will become effective upon signature and continue until cancelled by either party by written notice to the other. Amendments or modifications to this Agreement may be made upon written agreement by both parties to the Amendment.

APPROVED FOR STATE OF OREGON:

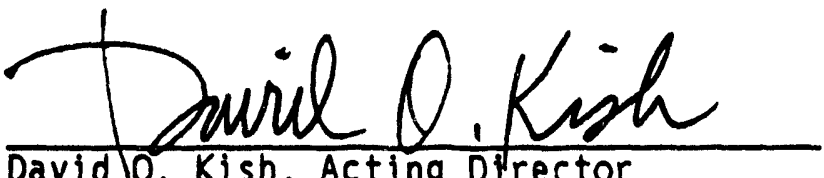

David 0. Kish, Acting Director

Oregon Department of Energy

APPROVED FOR THE DEPARTMENT OF ENERGY RICHLAND OPERATIONS OFFICE:

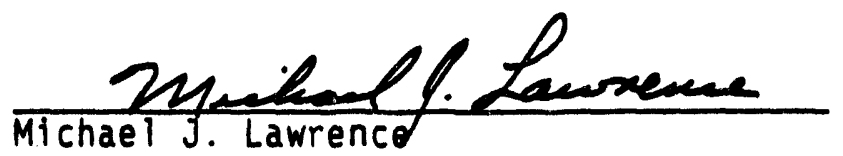
Manager

MWA:jf

$1179 L(d), f 1)$

$10 / 20 / 86$

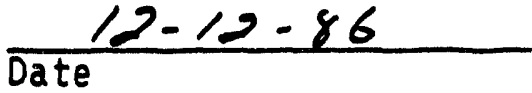


DOE/RL-94-02, Rev. 0

\section{TRI-CITIES MUTUAL AID AGREEHIENT}

THIS AGREEMENT, made and entered into on this $26 \mathrm{th}$ day of April 1985 by and between the Cities of Richland, Kennewick and Pasco and the Fire Protection Districts Benton County \#1, Benton County \#2, Benton County \#3, Benton County \#4, Benton County \#5, Benton County \#6, Frankl in County 13, Halla Walla County $\$ 5$ and the Hanford Fire Department.

\section{WITNESSETH:}

WHEREAS, each of the parties hereto maintains equipment and personnel for the suppression of fires within its own jurisdiction and areas, and

WHEREAS, the parties hereto desire to augment the fire and emergency medical protection available in their various establishments, districts, agencies and municipalities in the event of large fires or conflagrations or other disaster, and

WHEREAS, the lands or districts of the parties hereto are adjacent or contiguous so. that mutual assistance in a fire or medical emergency is deemed feasible, and

WHEREAS, it is the policy of the above municipalities or other districts and of their governing bodies to conclude such agreements wherever practicable, and 
Tri-Cities llutual fid Agreement,

Page 2

DOE/RL-94-02, Rev. 0

WHEREAS, it is mutually deemed sound, desirable, practicable, and beneficial for the parties to this agreement to render assistance to one another in accordance with these terms:

THEREFORE BE IT AGREED THAT:

1. Whenever it is deemed advisable by the commanding officer of a fire department belonging to a party to this agreement, or by the commanding officer of any such fire department actually present at any fire or other emergency including any medical emergency, to request assistance under the terms of this agreement, he is authorized to do so, and the commanding officer of the department receiving the request, or his authorized subordinates, shall forthwith take the following actions:

A. Immediately determine if apparatus and personnel can be spared in response to the call.

B. What apparatus and personnel might be most effectively dispatched.

C. The exact mission to be assigned in accordance with the detailed plans and procedures of operation drawn in accordance with this agreement by the technical heads of the fire departments concerned.

D. Forthwith dispatch such apparatus and personnel as, in the judgment of the responsible officer receiving the call, should be sent, with complete instructions as to the mission, in accordance with the terms of this agreenent.

2. The rendering of assistance under the terms of this agreement shall not be mandatory, but the party receiving the request for assistance should immediately inform the requesting agency if, for any reason assistance cannot be rendered. 
Tri-Citfes liutual Aid Agreement,

Page 3

DOE/RL-94-02, Rev. 0

3. A. Each party to this agreement waives all claims against the other party or parties for compensation for any loss, damage, personal injury or death occurring in consequence of the perfurmance of this agreement.

B. All service performed under this agreement shall be rendered without reimbursement of either party or parties.

4. The commanding officer of the fire department requesting assistance shall assume full charge of the operations, but if he specifically requests a senior officer of a fire department furnishing assistance to command, he shall not, by relinquishing command, be relieved of his responsibility for the operation; provided, that the apparatus, personnel and equipment. of the agency rendering assistance shall be under the immediate supervision of and shall be the immediate responsibility of the senior responding fire officer or the commanding officer of the department rendering assistance.

5. The chief fire officer and personnel of the fire departments of all parties to this agreement are invited and encouraged on a reciprocal basis, to frequently visit each other's activities for guided familiarization tours consistent with local security requirements and as feasible, to jointly conduct pre-fire planning inspections and drills.

6. The commanding officer of the fire departments of the parties to this agreement are authorized to meet and draft any detailed plans and procedures of operation necessary to effectively implement this agreement. Such plans and procedures of operation shall become effective upon ratification by the signatory parties. 
. . $\because$ Page 4 Tri-Cities llutual Aid Agreement,

DOE/RL-94-02, RON. 0

7. This agreement shall become effective upon the date hereof and shall remain in full force and effect until cancelled by mutual agreement of the parties hereto or by written notice by one party to the other party giving ten (10) days' notice of said cancellation.

17) WITNESS WHEREOF, the parties hereto have executed this agreement at Richlanda : Washington on the day and year first above written.
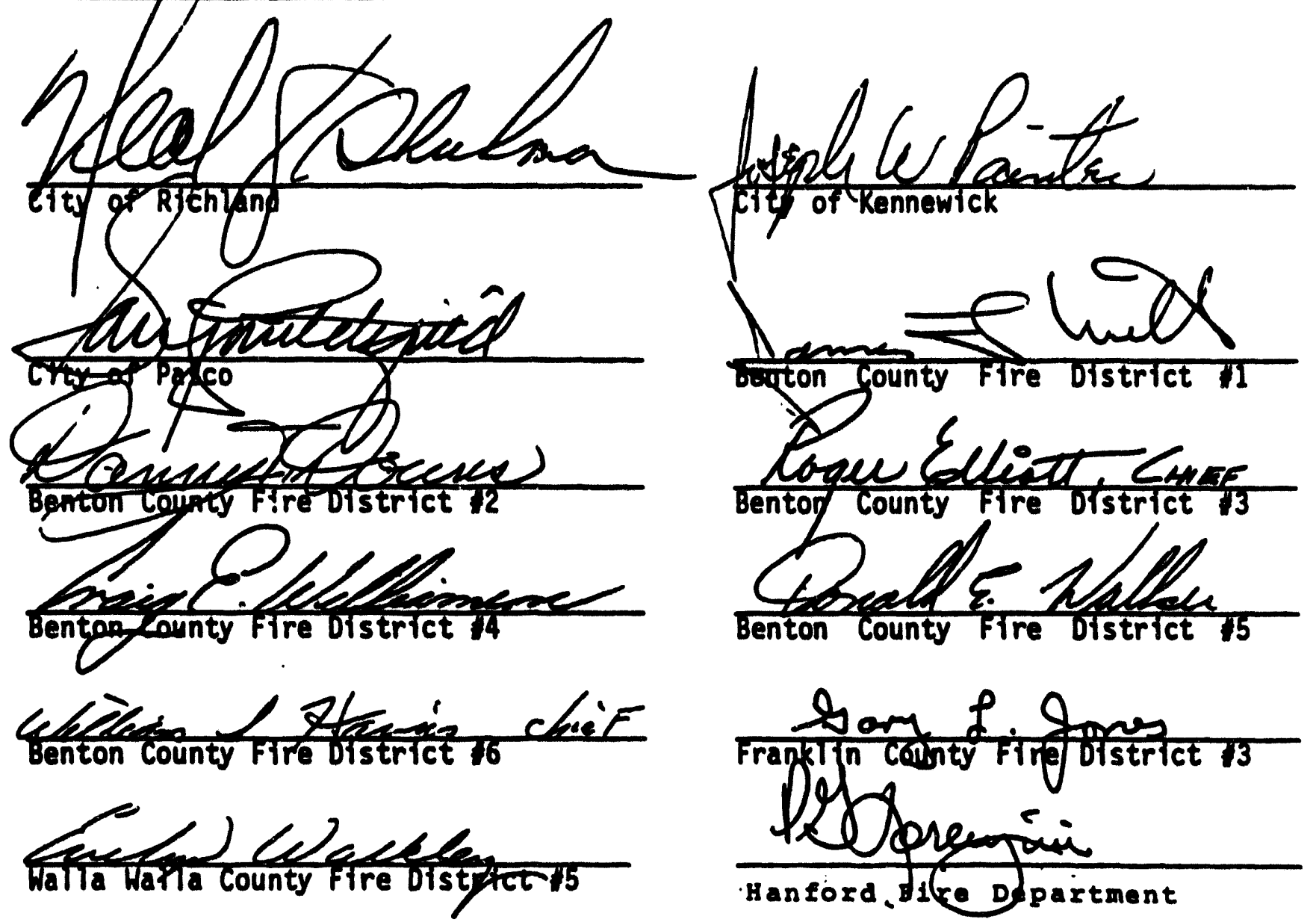

B-53 
DOE/RL-94-02, Rev. 0

MEMORANDUM OF AGREEMENT

For Mutual Law Enforcement Assistance

This Memorandum of Agreement (the "Agreement") is entered into between the United States Department of Energy (the "DOE") represented by the Richland Operations Office (DOE-RL) and the Benton County Sheriff (the "BCS").

\section{Recitals}

1. The BCS is the chief executive officer and conservator of the peace of Benton County, State of Washington. The DOE-RL Hanford Site is located in Benton County, Washington.

2. The DOE-RL security forces exercise law enforcement authority and maintain security on the DOE's Hanford Site as special deputies of the BCS and as federal officers authorized to carry firearms and make arrests pursuant to Section 161K of the Atomic Energy Act of 1954, as amended.

3. This Agreement is entered into by the DOE pursuant to the authority of the Atomic Eriergy Act of 1954, as amended, and by the BCS pursuant to RCW 10.98.130, which provides that any law enforcement agency may contract with any other such agency to provide mutual law enforcement assistance in order that the parties may perform their responsibilities described above.

4. This agreement shall be jointly administered by the Benton County Sheriff, James H. Kennedy, and the Director of Safeguards and Security Division, DOE-RL, Kenneth H. Jackson or their successors. 
5. There shall be no funds or property held under this Agreement. ARTICLE I - SCOPE

The general scope of this Agreement includes mutual law enforcement assistance, loan of special equipment, specialized training, and other assistance which may be identified by the parties from time to time. Specifically, the parties agree as follows:

A. The BCS, at his discretion and to the extent he is legally authorized to do so, agrees to commit available manpower and other resources to assist DOE-RL in dealing with security or law enforcement emergencies on the Hanford Site. Specific response plans may be developed by DOE-RL and submitted to the BCS for concurrence. DOE will provide any necessary training and special equipment and materials to facilitate the response by the BCS.

B. The DOE-RL will favorably consider providing assistance to the BCS in the execution of their law enforcement responsibilities, which assistance may include permitting the BCS temporarlly to use certain property and equipirerit, including where appropriate and necessary, operators for such equipment; the utilization of training facilities; specialized forensic science assistance, and other forms of assistance which the DOE-RL may be authorized and equipped to provide.

C. Each party to this Agreement may provide the other party the opportunity to allow personnel available to participate in unique training opportunities which may arise as the result of incidents or occurrences encountered in the course of law enforcement activities. Participation will be subject to avallability of manpower and accommodations.

MEMORANDUM OF AGREEMENT - 2 
DOE/RL-94-02, Rev. 0

ARTICLE II - REQUESTS FOR ASSISTANCE

A. Requests for assistance from the DOE-RL shall be made by the BCS or his official designee and shall be addressed to the Director, Safeguards and Security Division, DOE-RL. Each request shall be subject to approval on an individual case basis. Upon approval, the requested assistance will be provided, subject to the provisions of this Agreement and whatever additional conditions to which the parties may agree.

B. Requests for assistance from the BCS shall be made by the Director, Safeguards and Security Division, DOE-RL, and shall be addressed to the BCS. Each request shall be subject to approval of the BCS, or his official designee, on an individual case basis. Assistance provided by the BCS shall be subject to the provisions of this Agreement and to any other conditions as the parties may agree.

C. If the assistance provided by either party includes providing personnel, such personnel may operate under the general direction of, but shall not be deemed to be employees of the receiving party.

D. The DOE-RL may at its option provide any assistance requested hereunder through one or more of its Hanford onsite operating contractors.

\section{ARTICLE III-TERMINATION}

The term of this Agreement shal1 commence on Jure 11,1987 and is intended to be of indefinite duration. This Agreement or any activity thereunder may be terminated at any time upon written notice by either party to the other party. Notwithstanding the above, the parties agree to exercise their best efforts to avoid terminating any individual activity if to do so would substantially hinder the other party in the fulfillment of its mission. This Agreement may be amended in writing at any time by agreement between the undersigned parties.

MEMORANDUM OF AGREEMENT - 3 
DOE/RL-94-02, Rev. 0

ARTICLE IV - WAIVER OF CLAIMS

A. Except as otherwise provided in Article VII, the United States of America, by and through the DOE, for the sole consideration of any benefits derived from this Agreement, hereby waives, relinquishes, remisses, releases, and forever discharges BCS from any and all claims, actions, causes of actions, demands, rights, damages, costs, loss of service, expenses, and compensation whatsoever, which the undersigned now has/have or which may hereafter accrue on account of or in any way growing out of any and all known and unknown, foreseen and unforeseen bodily and personal injuries and property damage and the consequences thereof, resulting or to result in consequence of assistance rendered or activity conducted by the BCS under this Agreement.

B. Except as otherwise provided in Article VII, the BCS, for the sole consideration of any benefits derived from this Agreement, hereby waives, relinquishes, remisses, releases, and forever discharges the United States of America and the DOE from any and all claims, actions, causes of actions, demands, rights, damages, costs, loss of service, expenses, and compensation whatsoever, which the undersigned now has/have or which may hereafter accrue on account of or in any way growing out of any and all known and unknown, foreseen and unforeseen bodily and personal injuries and property damage and the consequences thereof, resulting or to result in consequence of assistance rendered or activity conducted by the DOE or its contractors under this Agreement.

MEMORANDUM OF AGREEMENT - 4 
I DOE/RL-94-02, Rev. 0

ARTICLE $V$ - PAYMENT

Except as provided in Article VII or as otherwise agreed in individual cases, no compensation shall be paid by the DOE or by the BCS for any assistance rendered pursuant to this Agreement.

ARTICLE VI - DISCLAIMER OF WARRANTIES

Neither the DOE nor the BCS makes any representations or warranty as to the physical condition or usefulness of any equipment, information, training, or other assistance exchanged under this Agreement or the fitness for any particular purpose to which any such equipment, information, training, or other assistance may be put by the recipient.

ARTICLE VII - LOSS OR DAMAGE TO PROPERTY AND EQUIPMENT

Property and equipment which may be loaned by one party to the other under this Agreement shall be returned in as good condition as when it was received by the using party, reasonable wear and tear excepted. The using party agrees to reimburse the lending party for any loss or damage of any nature to the property or equipment which is caused by or arises from activities of the user.

\section{ARTICLE VIII - ASSIGNMENT}

The BCS shall not assign this Agreement or any interest therein or any claim thereunder, except as expressly authorized in writing by the DOE.

MEMORANDUM OF AGREEMENT - 5 


\section{DOE/RL-94-02, Rev. 0}

IN WITNESS WHEREOF, the parties hereto have executed this Agreement as of Juer 10,1987

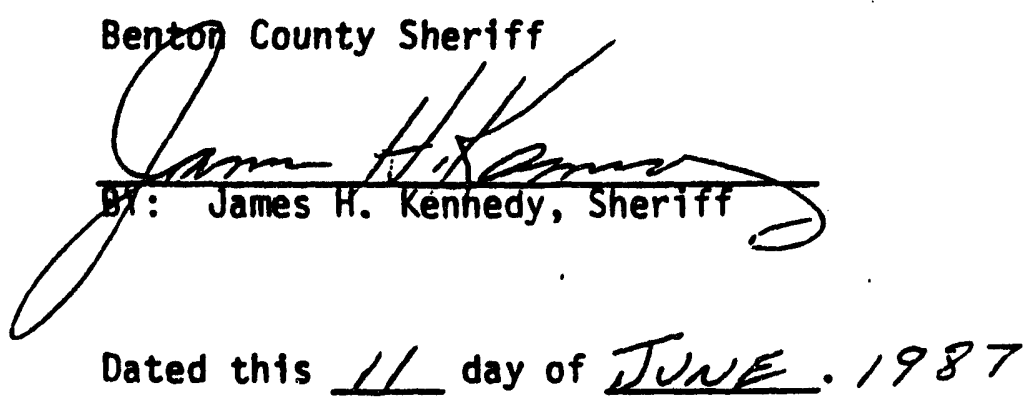

United States Department of Energy

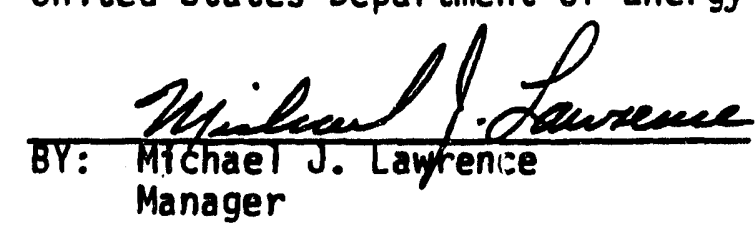

MEMORANDUM OF AGREEMENT - 6 
DOE/RL-94-02, Rov. 0

This page intentionally loft blank. 

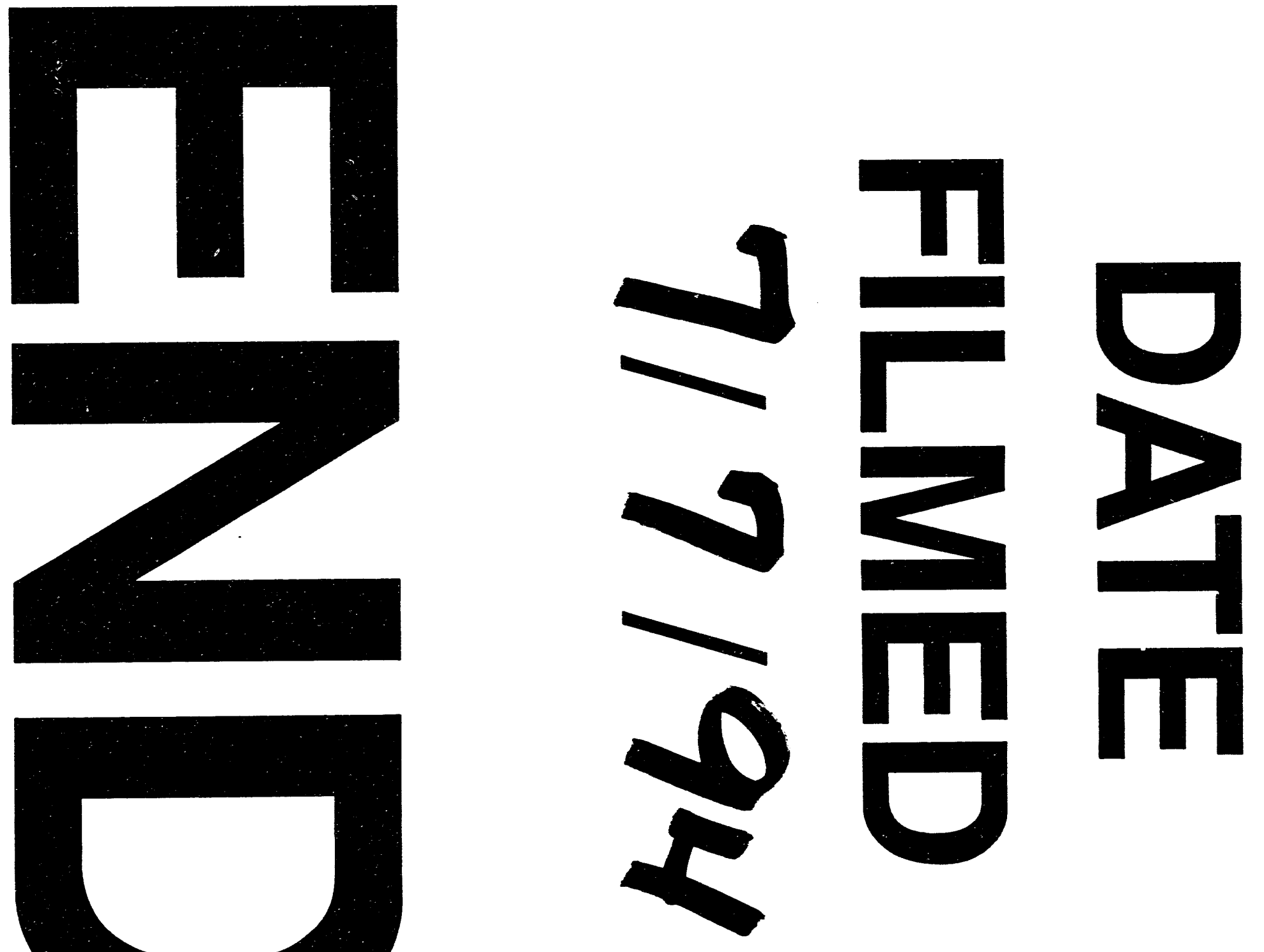

$上$

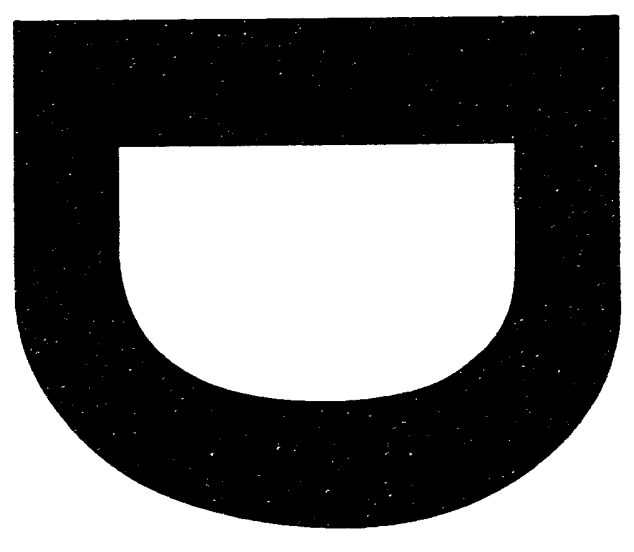


